\title{
SUNTINGAN TEKS NASKAH PIDATO-PIDATO ADAT MINANGKABAU
}

\author{
Melia Roza $^{1^{*}}$, Pramono ${ }^{2}$, Yerri Satria Putra ${ }^{3}$ \\ meliaroza@gmail.com* \\ Fakultas Ilmu Budaya Universitas Andalas, 1,2,3
}

\begin{abstract}
ABSTRAK
Tulisan ini menyajikan hasil suntingan teks pidato adat Minangkabau yang dapat terbaca oleh khalayak umum. Teori yang digunakan dalam penelitian ini adalah teori filologi, dengan menggunakan pendekatan modern, yaitu menitikberatkan kajiannya pada teks sebagai suatu hasil kreativitas dari penyalin atau penulisnya. Metode yang digunakan adalah metode kritik teks, dengan penerapan edisi naskah tunggal. Tahapan yang dilakukan dalam penelitian adalah: pengumpulan data, deskripsi naskah, menentukan metode, melakukan transliterasi.
\end{abstract}

Kata-kata kunci: Pidato Adat, Minangkabau, Suntingan, Manuskrip.

\section{TEXT EDITION OF THE MINANGKABAU PIDATO ADAT MANUSCRIPT}

\section{ABSTRACT}

This paper presents the edited text of the Minangkabau traditional speech that the general public can read. The theory used in this research is philological, using a modern approach, which focuses on the study of the text due to the creativity of the copyist or the author. The method used is the text criticism method, with the application of a single manuscript edition. The stages carried out in the study were: data collection, description of the manuscript, determining the method, transliterating.

Keywords:Pidato Adat, Speech, Minangkabau, Text Edition, Manuscript.

Jurnal Elektronik WACANA ETNIK - Vol 8 No 1, 2019, (44 - 117) p ISSN 2089-8746, e ISSN 2302-7142

Submit: Februari 2019. Diterima: Maret 2019. Publikasi: April 2019. 


\section{PENGANTAR}

Pidato disampaikan di hadapan banyak orang dan memerlukan kemahiran dalam penyampaiannya. Pidato disampaikan satu arah dan tidak berbalas, hal tersebut berbeda dengan pasambahan, menurut Djamaris (2002: 44), pasambahan adalah pembicaraan dua pihak, dialog antara tuan rumah (si pangka) dan tamu (si alek) untuk menyampaikan maksud dan tujuan dengan hormat.

Kemajuan yang terlihat dari kesusastraan lisan Minangkabau adalah, orang-orang Minangkabau mulai menuliskan khazanah sastra lisan dengan menggunakan aksara Arab-Melayu (Jawi); yang kemudian dalam perkembangannya menggunakan aksara Latin. Hal tersebut disampaikan Suryadi dalam buku Syair Sunur: teks dan konteks otobiografi seorang ulama Minangkabau abad ke-19 (2004: 4), bahwa aksara Jawi dikenal luas di Minangkabau pada abad ke-18 - kemudian disusul dengan pengenalan aksara Latin, yang pada akhirnya khazanah sastra lisan Minangkabau banyak dituliskan.

Kemajuan khazanah sastra lisan menjadi sastra tulis, melahirkan naskah-naskah yang masih dapat ditemukan sampai sekarang, seperti naskah keagamaan, sastra, kesehatan, kebudayaan dan lainnya. Naskah-naskah yang ditulis oleh para ulama pada masanya, memiliki nilai yang dapat dijadikan sebagai bahan pengajaran,serta di dalamnya terdapat kandungan produk budaya masa lampau yang patut untuk diteliti.

Dinamika penulisan naskah di Minangkabau tidak bisa dilepaskan dari proses intelektual ulama Minangkabau. Menurut Pramono (2013: 111-112), wacana Islam lokal di Sumatera Barat telah melahirkan corak yang khas dankemudian melahirkan dua golongan keagamaan, yaitu golongan tua dan muda yangsaling berpolemik. Polemik keislaman pada masanya, berdampak terhadap suburnya tradisi penyalinan dan penulisan naskah. Proses penulisan dan penyalinan naskah — sastra lisan yang dituliskan-tidak membuat sastra lisan Minangkabau terpinggirkan. Keberadaan sastra lisan di tengah masyarakat Minangkabau masih tetap ditampilkan sebagai sebuah pertunjukan yang diminati, walaupun saranayang digunakan dalam penyampaiannya sudah hadir dalam bentuk lain, seperti dalam bentuk tulisan, rekaman suara dan gambar. Walau demikian, ketiganya tetaphidup berdampingan di tengah masyarakat. Amir (2003) melihat hal tersebut dari sudut pandang filologi dan mengatakan bahwa dalam masyarakat Minangkabau teks lisan, naskah, dan teks cetakan hidup bersama-sama.

Tradisi penulisan naskah pada akhirnya melahirkan banyak naskah diMinangkabau, salah satunya adalah naskah pidato adat. Naskah pidato adat ini adalah naskah yang berisi kumpulan pidato adat Minangkabau, seperti pidato kawin, pidato manjapuik marapulai khusus, pidato menyusun kedudukan dan beberapa pidato lainnya. Panjang naskah pidato adat Minangkabau ini adalah 162 halaman, ditulis dengan menggunakan aksara Arab-Melayu (Jawi). Naskah pidato-pidato adat Minangkabau ini telah dipelajari oleh Adjisman/Adjisam Sutan Pamenan pada tahun 1934 sampai tahun 1937 kepada beberapa orang gurunya yang berasal dari tempat yang berbeda. Buku pidato adat Minangkabau milik Adjisman Sutan Pamenan dipinjam dan dipelajari oleh anak beliau yaitu St Pamenan A.G. Ismael Sutan Batuah. Buku tersebut ditulis dan disusun ulang pada tahun 1981 di Medan dengan judul —Naskah PidatoPidato Adat Minangkabau. 
Penelitian terhadap naskah pidato adat — yaitu transliterasi dan suntingan teks — belum ditemukan oleh peneliti. Hal tersebut berbanding terbalik dengan keberadaan kaba dan pantun, di mana kebanyakan peneliti lebih tertarik dengan 2 jenis kesusastraan tersebut. Hal itu dapat dilihat dalam catatan Ekadjati (2000: 406-443), yang hanya menyebut naskah kaba dan pantun dalam judul-judul naskah Minangkabau yang pernah diteliti oleh peneliti naskahuntuk naskahbertema sastra - sedangkan naskah pidato tidak termasuk ke dalam daftar naskah yang disusunnya. Hal yang sama juga ditemukan dalam Thesaurus Of Indonesian Islamic Manuscripts yang di dalamnya terdapat ribuan penelitian tentangnaskah, namun tidak ditemukan naskah pidato termasuk ke dalam daftar naskah yang diteliti. Keberadaan pidato yang kurang diminati juga disampaikan Suryadi(2002: 2), bahwa dalam tradisi kajian naskah Nusantara - khususnya Melayu — cenderung para peneliti (peneliti Barat dan Indonesia), lebih memfokuskan kepada teks-teks panjang atau prosa sejarah, epos-epos besar, historiografi tradisional atau hikayat-hikayat kerajaan, dari pendapat Suryadi tersebut maka dapat disimpulkan bahwa naskah pidato adat Minangkabau menjadi objek penelitian yang kurang diminati.

\section{KERANGKA TEORI DAN METODE}

Filologi merupakan satu disiplin yang ditujukan pada studi tentang teks yang tersimpan dalam peninggalan tulisan masa lampau. Studi teks ini didasari oleh adanya informasi tentang hasil budaya manusia pada masa lampau yang tersimpan di dalamnya (Baroroh, 1994: 4). Menurut Barid (1994: 5), sebagai suatubentuk studi, filologi diperlukan karena munculnya variasi-variasi dalam teksyang tersimpan dalam naskah. Maka dapat dikatakan, bahwa bidang filologi tidak bisa dipisahkan dari naskah dan teks.

Dalam kajian filologi dikenal 2 pendekatan, yaitu pendekatan tradisionaldan modern. Menurut Baried (1994: 5), pendekatan tradisional adalah sikap yang memandang variasi sebagai satu bentuk korup yang berarti sebagai wujud kelengahan dan kelalaian penyalin. Pendekatan modern adalah memandang variasi yang terdapat pada teks sebagai suatu yang positif, pendekatan ini menampilkan wujud resepsi si penyalin. Dari dua pendekatan filologi tersebut, peneliti menggunakan pendekatan modern, yaitu menitikberatkan kajiannya pada teks sebagai suatu hasil kreativitas dari penyalin atau penulisnya. Kesalahan dan perbedaan yang ada pada teks, baik disengaja atau tidak, dianggap sebagai suatu hal yang positif dan kreatif.

Menurut Baried (1994: 55) naskah dalam kajian filologi adalah tulisan tangan yang menyimpan berbagai ungkapan pikiran dan perasaan sebagai hasil budaya masa lampau. Naskah adalah benda konkret yang dapat dilihat atau dipegang. Menurut Madan (dalam Mulyadi, 1994: 3), naskah biasa juga disebut manuskrip. Kata manuscript diambil dari ungkapan Latin codicesmanu scripti artinya buku-buku yang ditulis dengan tangan.

Menurut Mamat (dalam Mulyadi, 1994: 12), manuskrip Melayu adalah apa-apa tulisan Jawi/Rumi berbahasa Melayu yang ditulis dengan tangan di atas bahan-bahan seperti kertas, kulit, daun lontar, buluh, gading, kayu, kain, denganisi kandungan dan jangka waktu yang tidak terbatas, manuskrip bertulis dalam bahasa Aceh dan Minangkabau dianggap sebagai manukrip Melayu. Dalam khazanah Melayu (termasuk Minangkabau), naskah yang menjadi bahan kajian filologi dapat berupa salinan tangan dan cetakan.

Jurnal Elektronik WACANA ETNIK - Vol 8 No 1, 2019, (44 - 117) p ISSN 2089-8746, e ISSN 2302-7142 
Menurut Mulyadi (1994: 3) teks adalah apa yang terdapat di dalamsuatu naskah. Sedangkan pengertian yang lebih detail disampaikan oleh Baried (1994: 57), bahwa teks adalah kandungan atau muatan naskah, sesuatu yang abstrak yang hanya dapat dibayangkan saja. Teks terdiri atas isi, yaitu ide-ide atauamanat yang hendak disampaikan pengarang kepada pembaca dan bentuk, yaitu cerita dalam teks yang dapat dibaca dan dipelajari menurut berbagai pendekatan melalui alur, perwatakan, gaya bahasa, dan sebagainya.

Robson (dalam Pramono, 2015: 44-45) mengemukakan bahwa -Pada dasarnya, pendekatan filologi digunakan untuk menjambatani komonikasi antara teks yang terkandung di dalam naskah dengan pembaca. Oleh sebabnya, seorang pengkaji naskah mestilah mengetengahkan teks - terbacall dan melakukan interpretasi terhadapnya supaya boleh dimengerti oleh khalayak luas. Dari pendapat tersebut, maka perlu diadakannya suntingan teks dari naskah yang diteliti.

Tahapan yang dilakukan dalam penelitian adalah: pertama, pengumpulan data. Pengumpulan data dilakukan dengan mencatat dan mendaftar naskah pidato-pidato adat yang ada di berbagai katalogus. Kedua, deskripsi naskah. Setelah melakukan pencatatan dan mendaftar naskah melalui katalogus, maka langkah selanjutnya adalah deskripsi naskah. Deskripsi naskah meliputijudul naskah, bahasa dan ejaan yang digunakan, pemilik naskah, tahun ditulis naskah, jumlah halaman naskah dan ringkasan tentang isi naskah.

Ketiga, menentukan metode yang tepat untuk digunakan dalam penelitian naskah pidato-pidato adat. Metode yang digunakan adalah metode kritik teks, dengan penerapan edisi naskah tunggal. Menurut Baroroh (1994: 67), metode naskah tunggal dilakukan dengan 2 cara, pertama edisi diplomatik, yaitu menerbitkan satu naskah setelititelitinya tanpa mengadakan perubahan. Edisi diplomatik yang baik adalah hasil pembacaan yang teliti oleh seorang pembaca yang ahli dan berpengalaman. Dalam bentuknya yang paling sempurna, edisidiplomatik adalah naskah asli direproduksi fotografis. Dapat juga penyuntingmembuat transliterasi setepat-tepatnya tanpa menambahkan sesuatu.

Kedua, edisi standar atau edisi kritik, yaitu menerbitkan naskah dengan membetulkan kesalahan-kesalahan kecil dan ketidakajegan sedang ejaannya disesuaikan dengan ketentuan yang berlaku. Diadakan pengelompokan kata, pembagian kalimat, digunakan huruf besar, pungtuasi, dan diberikan pula komentar mengenai kesalahan-kesalahan teks. Selanjutnya, segala usaha perbaikan harus disertai pertanggungjawaban. Tambahan dari Fathurahman (2010: 22), edisi kritis adalah hasil oleh penyunting yang menginginkan terbentuknya sebuah teks dengan kualitas bacaan terbaik (best readings). Hal yang dilakukan dalam edisi ini adalah, seperti pengurangan, penambahan, atau penggantian kata dalam teks. Untuk naskah pidato-pidato adat peneliti menggunakan edisi standar atau edisi kritik. Keempat, melakukan transliterasi. Transliterasi dilakukan dengan mengganti huruf demi huruf dari aksara ArabMelayu ke tulisan Latin, dengan berpedoman kepada aturan yang baru (PUEBI).

\section{HASIL DAN PEMBAHASAN}

Naskah dengan judul -Pidato-Pidato Adat Minangkabaul ini adalah naskah yang berisi pasambahan, pidato adat, jenis-jenis adat, syarat-syarat menjadi seorang panghulu dan falsafah pakaian panghulu. Sebagian besar naskah berisi kumpulan pidato adat Minangkabau, sehingga naskah ini diberi judul —Pidato- Pidato Adat Minangkabaull. 
Pidato-pidato adat yang terdapat di dalam naskah,pada awalnya naskah dipelajari oleh Adjisman/Adjisam (Penulisan Huruf pada naskah tidak terlalu jelas) Sutan Pamenan pada tahun 1934 sampai tahun 1937 kepada beberapa orang gurunya. Dalam penjelasan singkat tentang naskah disebutkan bahwa buku pidato adat tersebut dipinjamkan kepada anak beliau yang bernama Dt. St. P-a-m-e-n A.G. Ismael Sutan Batuah, kemudian buku tersebut dipelajari dan ditulis ulang pada tanggal 01 Agustus 1981 di Medan.

Naskah pidato-pidato adat Minangkabau ini memiliki jumlah halaman sebanyak 162 halaman, untuk pemberian nomor halaman dari naskah tidak keseluruhan halaman diberi nomor. Pemberian nomor halaman diberikan pada lembar halaman yang terdapat judul baru, seperti halaman satu untuk judul kapalo pasambahan, kemudian pemberian halaman langsung ke halaman 4 dengan judul baru dan seterusnya.

Penulisan naskah ini tidak seperti kebanyakan penulisan pidato adat Minangkabau, yaitu bait perbait dengan membagi halaman buku menjadi dua bagian, namun naskah ini ditulis dengan gaya penulisan dijejerkan dari margin kirike margin kanan pada halaman kertas dengan memberi tanda (-) untukmenentukan tanda jeda. Oleh penyunting, format tersebut dipindahkan pada halaman kertas yang dijejerkan dari margin kiri ke margin kanan dengan penambahan tanda baca.

Dari segi bahasa yang digunakan, naskah pidato adat Minangkabau ini menggunakan bahasa Minangkabau yang dipengaruhi oleh bahasa Melayu. Menurut Roesli (dalam Yusuf, 2017: 117), bahasa Minangkabau adalah bahasa yang digunakan oleh anak negeri dalam Minangkabau, yaitu daerah yang sekarangdisebut Sumatra Barat. Dari pendapat tersebut, Yusuf menambahkan, bahwa bahasa Minangkabau adalah bahasa yang digunakan oleh anak negeri Minangkabau, yaitu daerah Sumatera Barat kecuali kepulauan Mentawai.

Di sisi lain St. Majolelo (dalam Yusuf, 2017: 117), berpendapat bahwa pada hakikatnya, yang dianggap (oleh masyarakat Minangkabau) sebagai bahasa Minangkabau adalah bahasa Melayu, dan mereka menulis surat dalam bahasa Melayu tinggi. Medan (dalam Yusuf, 2017: 118-119), mengatakan bahwa banyak ahli yang berpendapat bahasa Minangkabau merupakan dialek (berada di bawah) bahasa Melayu, tetapi banyak pula yang mengemukakan pendapatnya bahwa bahasa Minangkabau setingkat (di sebelah) bahasa Melayu.

Dari pendapat St. Majolelo dan Medan tersebut dapat dikatakan bahwa antara bahasa Melayu dan bahasa Minangkabau memiliki hubungan yang cukup dekat, sehingga tidak mengherankan jika di dalam naskah pidato-pidato adat Minangkabau ini terdapat bahasa Melayu. Hal tersebut dikarenakan beberapa hal, menurut Amir (dalam Yanti, 2007: 21), bahasa Melayu hanya memiliki sedikit perbedaan dengan bahasa Minangkabau, yakni pada pengucapannya saja. Di samping itu, masyarakat Minangkabau merasa bahwa menggunakan bahasa Minangkabau tidak banyak bedanya dengan menggunakan bahasa Melayu, sehingga jika orang Minangkabau menggunakan bahasa Minangkabau dalam bahasa Melayu, mereka merasa telah menggunakan bahasa Melayu tanpa perlu berusaha mencari kata yang tepat dan sesuai dalam bahasa Melayu. Bagi orang Minangkabau, orang yang menggunakan bahasa Melayu dikatakan berbahasa Melayu Tenggih, dan menggunakan bahasa Minangkabau tidak dikatakanberbahasa Melayu rendah, namun sering dikatakan berbahasa 'caro awak'.

Jurnal Elektronik WACANA ETNIK - Vol 8 No 1, 2019, (44 - 117) p ISSN 2089-8746, e ISSN 2302-7142 
Selain itu, faktor yang menyebabkan aksara Arab-Melayu dapat terbaca dalam dua bahasa, yaitu Melayu dan Minangkabau dikarenakan beberapa hal, seperti yang diungkapkan Medan (dalam Yusuf, 2017: 125), bahasa Minangkabau tidak mempunyai tradisi tulisan, mereka lebih cenderung menggunakan tradisi lisan. Tradisi tulisan baru dikenal di Minangkabau setelah Islam masuk. Pengenalan terhadap tradisi tulisan dapat dikatakan sejalan dengan pengenalan melalui ejaan Arab-Melayu. Oleh karena itu, orang Minangkabau, dalam bahasa tulis, cenderung menggunakan Bahasa Melayu.

Menurut Edwar Djamaris (dalam Yusuf, 2017: 126), faktor lain yang mempengaruhinya adalah kecenderungan masyarakat Minangkabau mengindonesiakan kata-kata yang berasal dari bahasa Minangkabau, kemudian menganggap dirinya telah berbahasa Indonesia dan menganggap telahmenggunakan bahasa Indonesia, tanpa perlu mencari padanan kata yang lain (yang benar-benar merupakan kata bahasa Indonesia), seperti nama-nama tempat, yaitu Tabiang, Lubuak Bagaluang, Padang Laweh, Alang Laweh, Limapuluh kotodan Kubu Karambia, masing-masing di Indonesiakan menjadi Tabing, Lubuk Begalung, Padang Lawas, Alang Lawas, Limapuluh Kota dan Kubu Kerambil. Padahal menurut makna yang terkandung di dalamnya, kata-kata itu semestinya diindonesiakan menjadi Tebing, Lubuk Bergelung, Padang Luas, Halangan Luas (Betapa Luas), Limapuluh Koto.

Secara umum bahasa yang digunakan di dalam naskah —Pidato-Pidato Adat Minangkabau ini menggunakan bahasa Minangkabau yang dipengaruhi bahasa Melayu. Bahasa-bahasa Melayu yang ditemukan di dalam naskah, seperti kata adat, air, dinding, isteri, akhiran -nya', nama-nama tempat (Candung, Batipuh, Lubuk Alung, Sungai Puar), diubah penulisannya menjadi adaik, aia, dindiang, bini, Canduang, Batipuah, Lubuak Aluang, dan Sungai Pua.

Bahasa yang digunakan dalam Pidato-Pidato Adat Minangkabau ini tidakkeseluruhan berbahasa Minang, namun ditemukan beberapa kata berbahasa Arab. Kata-kata berbahasa Arab seperti potongan ayat-ayat Al Quran dan istilah-istilah pendek. Contoh kata berbahasa Arab yang ditemukan di dalam naskah, seperti; Waati'ullaha wa ati'ur rasula,qatib taklif, qatlib wadak, jazam,ghairu jazam,khayar, dan lainnya.

Bahasa Arab yang terdapat di dalam naskah, sebagiannya diterjemahkan oleh penulis naskah, namun tidak semua kata dalam bahasa Arab tersebut yang diterjemahkan, untuk kata yang tidak diterjemahkan maka oleh penyuntingdibuatkan arti kata tersebut pada catatan kaki. Sedangkan untuk penggunaan aksara Latin ditemukan pada bagian akhir naskah yang bercerita tentang pemaparan naskah Pidato-Pidato Adat secara singkat, selain itu aksara Latin juga ditemukan untuk menjelaskan kata dalam aksara Arab-Melayu yang tidak terbaca, aksara Latin tersebut ditulis dalam tanda kurung (..)

Di dalam naskah terdapat beberapa buah penggunaan kata beraksara Latin yang dibubuhi tanda kurung. Penulis menemukan kata-kata beraksara Latin tersebut karena 2 hal:

1. Menambahkan kata beraksara Latin di samping aksara Jawi yang sulit terbaca. Kata beraksara Latin tersebut dibubuhi dalam tanda kurung, seperti yang terdapat dalam pidato mangatangahkan hidangan halaman 34 dalam naskah.

Jurnal Elektronik WACANA ETNIK - Vol 8 No 1, 2019, (44 - 117) p ISSN 2089-8746, e ISSN 2302-7142 
2. Menambahkan kata beraksara Latin sesudah kata yang masih bisa terbaca dalam aksara Jawi, seperti yang terdapat di dalam - alua bayang tinggi halaman 91. Di dalam naskah terdapat kata tabao yang masih dapat terbaca, namun penyalin naskah membuat kata tabao lagi dalam aksara Latin.

\section{RINGKASAN TEKS}

Naskah ini berisi berbagai kumpulan pidato adat Minangkabau, pasambahan, jenis adat, syarat-syarat menjadi seorang panghulu dan falsafah pakaian panghulu. Pada bagian awal naskah dibuka dengan pasambahan, yaitu sambah anam dan sambah ampek. Isi dari sambah anam adalah penghormatan kepada panghulu, alim ulama, hulubalang, manti, pagawai, cadiak pandai, serta seisi rumah gadang. Sambah ampek berisi penghormatan kepada niniak mamak, tuangku, cadiak pandai, serta seluruh orang yang hadir pada saat acara. Sambah ampek merupakan jawaban dari sambah anam.

Di dalam naskah terdapat 18 pidato adat, seperti:

\section{Pidato Kumango}

Pidato kumango menjelaskan tentang kewajiban orang tua laki-laki kepada anaknya, serta tentang semua peraturan yang sudah disepakati untuk anak laki-laki dan perempuan, selain itu juga dijelaskan 2 jalan yang harus dituruti, yaitu jalan agama dan jalan adat.

\section{Pidato Kawin}

Pidato kawin ini menjelaskan hutang orang tua kepada anak-anaknya, seperti hutang orang tua kepada anak laki-laki, yaitu membayar pitah sang anak, mengkhitankan dan menggunting rambut sang anak. Selain itu, di dalam pidato kawin ini dijelaskan tentang kewajiban seorang laki-laki dewasa, seperti menjadi imam, katik dan panghulu. Selain hutang orang tua kepada anak laki-laki, didalam pidato kawin ini juga dijelaskan 4 hutang orang tua kepada anak perempuannya. Empat macam hutang tersebut adalah, dibaok turun, taurai rambuik, batatahkakadi, mencari junjungan.

Di dalam pidato ini juga dijelaskan ketika seorang anak sudah menemukan jodohnya, yaitu memanggil ninik mamak untuk mendiskusikan mengenai perkawinan tersebut. Di dalam pidato ini juga dijelaskan pernak pernik yang digunakan saat pernikahan, serta dari mana asalnya, seperti kata-kata "Dibantangkan lapiak parmadani, buatan anak urang Yaman, pakirin rajo dari Arab”. Di dalam pidato ini juga disebutkan makanan yang disediakan serta rumah gadang yang dipenuhi oleh kedatangan orang banyak.

\section{Pidato Siriah}

Di dalam naskah terdapat 2 buah pidato siriah, yaitu pidato siriah 1 dan pidato siriah 2 . Di dalam pidato siriah 1 menjelaskan tentang isi carano. Isi carano yang dijelaskan di dalam naskah seperti siriah, gambir dan pinang. Selain isi carano, pada bagian akhir pidato dijelaskan tentang perintah untuk mengunyah sirih yang telah disediakan. Pidato siriah 2 menjelaskan tentang sirih yang sudah terletak di bagian tengah rumah, dan diperintahkan juga untuk mengunyahnya.

\section{4. $\quad$ Pidato Rumah Gadang}

Jurnal Elektronik WACANA ETNIK - Vol 8 No 1, 2019, (44 - 117) p ISSN 2089-8746, e ISSN 2302-7142 
Pidato rumah gadang di dalam naskah berjumlah 2 buah, pertamapidato rumah gadang 1 dan pidato rumah gadang 2. Pidato rumah gadang menjelaskan tentang bahan-bahan yang digunakan dalam membuat rumah gadang, seperti membuat tiang, singok, serta nama ukiran dari rumah gadang tersebut. Di dalam juga dijelaskan nama kayu yang digunakan untuk membangun rumah gadang, dan asal tukang yang membangun rumah gadang. Di dalam naskah pidatorumah gadang ini juga dijelaskan nama-nama rangkiang.

\section{Pidato Mangatangahkan Hidangan}

Di dalam naskah terdapat 2 buah pidato mangatangahkan hidangan, yaitu pidato mangatangahkan hidangan 1 dan 2. Pada bagian akhir pidato, diperintahkan untuk memulai makan.

\section{6. $\quad$ Pidato Alam Pendek}

Di dalam naskah terdapat 3 buah pidato alam pendek. Pertama menjelaskan tentang tiga orang ninik yang bersaudara, ketika ninik tersebut menikah dengan 3 orang puti yang turun dari kayangan. Mereka dinikahkan oleh malaikat. Selain itu juga dijelaskan tentang ketiganya pergi berlayar untuk mencari tempat pemberhentian, dengan tujuan berbeda-beda. Daerah-daerah yang menjadi tujuan mereka adalah Banuruhun, Banu Cino, dan ke Pulau Ameh.

Pada pidato alam pendek kedua menjelaskan tentang dua orang datuak, yaitu Datuak Parpatiah Nan Sabatang dan Datuak Katumangguangan. Selain itu, di dalam pidato ini juga dijelaskan pembagian daerah-daerah kebesaran 2 orang datuak tersebut. Pidato alam pendek yang terakhir, menjelaskan asal mula bumi tentang Gunung Marapi yang baru muncul, serta cerita tentang Puti Saklani. Secaraumum, naskah ini membahas tentang Datuak Katumangguangan dan Datuak Parpatiah Nan Sabatang. Ketiga pidato alam pendek ini menjelaskan tentang tambo asal-asul Minangkabau.

\section{Pidato Mangatangahkan Adaik}

Pidato ini menjelaskan tentang penghormatan untuk orang yang meninggal. Di dalam pidato ini dijelaskan hal-hal yang dilakukan untuk orang yang meninggal (menurut Islam), seperti mengantar ke kubur dan mendoakan. Pidato ini juga menjelaskan alat yang digunakan untuk memberitakan kepadaorang banyak tentang adanya kematian, pemberitahuan dilakukan dengan membunyikan tabuah dan badia.

\section{8. $\quad$ Pidato Alam Pendek Mandirikan Panghulu}

Pidato ini menjelaskan asal mulanya luhak, serta daerah-daerah yang terdapat di dalamnya. Pidato ini juga menjelaskan nama-nama datuak yang memerintah, seperti Datuak Mangkudun di Sumaniak, Tuan Kali di Padang Gantiang, dan daerah lainnya.

\section{9. $\quad$ Pidato Alam untuk Mandirikan Panghulu}

Pidato ini menjelaskan nama-nama tempat serta 2 buah kelarasan.

\section{Pidato Mintak Doa yang Meninggal}

Pidato ini menjelaskan tentang permintaan maaf untuk yang meninggal, orang-orang yang datang diminta memberikan maaf dan doa untuk yang meninggal. Selain itu, di dalam pidato ini dijelaskan tentang hutang-piutang orang yang meninggal.

\section{Pidato Minta Maaf Karano Janang Akan ka Tangah}

Jurnal Elektronik WACANA ETNIK - Vol 8 No 1, 2019, (44 - 117) p ISSN 2089-8746, e ISSN 2302-7142 
Pidato ini menjelaskan keberadaan janang sebagai yang mengatur acara, seperti permintaan maaf kepada yang hadir, bahwa yang mengatur acara akan pergi ke tengah-tengah orang banyak.

12. Pidato Mintak Bajalan Baiyo

Pidato ini dilakukan oleh 2 pihak, pada akhir pidato disampaikan kalimat seperti berikut: diharap buni nak kambali.

13. Pidato Manjapuik Marapulai Khusus

Pidato ini menjelaskan tentang permintaan pihak perempuan kepada pihak laki-laki untuk membawa marapulai ke rumah anak daro.

\section{Pidato Manyusun Kadudukan}

Pidato ini menjelaskan tentang keadaan alek jamu saat perhelatan, seperti kata-kata: limbago sabuang bajuaro, alek jamu basapanggkalan, karano alek lah tibo, limbago jamu lah datang. Pidato ini disampaikan oleh si pangkalan.

\section{Pidato Mintak Diri Sacaro Pendek}

Pidato ini diawali dengan perumpamaan seorang nakoda yang sedangberlayar. Kemudian pelayaran nakoda tersebut selamat sampai tujuan. Hal tersebut untuk mengatakan permintaan maaf urang si pangka.

16. Pidato Mulo-Mulo Akan Mambukan Parundiangan

17. Pidato Uraian Kato Nan Tujuan

18. Pidato Mintak Turun Tanggo

Pidato ini menjelaskan tentang pemulangan salam kepada tuan rumah (sutan), pidato ini disampaikan ketika tamu sudah selesai dengan makan dan minumnya dan hendak pamit turun dari rumah yang punya alek.

Selain pidato adat, di dalam naskah juga menjelaskan tentang syarat- syarat menjadi panghulu, palsapah pakaian panghulu, pembagian luhak nan tigo dan rantau nan duo, pembagian adat, hukum maisbatkan (menetapkan) sesuatu danmenapikan sesuatu, bajalan baiyo bakato bamulo. Dari beberapa pidato yang terdapat di dalam naskah, sebagian pidato diawali dengan kata-kata didahului dengan kapalo pasambahan.

Adapun hasil suntingan teks pidato adat ini disampaikan pada bagian akhir artikel sebagai lampiran.

\section{PENUTUP}

Naskah Pidato-Pidato Adat Minangkabau ini ditulis oleh A.G. Ismael Sutan Batuah pada tahun 1981 di Medan. Bahasa yang digunakan adalah bahasa Minangkabau yang dipengaruhi oleh bahasa Melayu. Transliterasi yang dilakukanpada naskah ini menghadirkan naskah yang awalnya beraksara Arab-Melayu kepada aksara Latin. Dari proses transliterasi ditemukan sejumlah kata yang tidak dapat terbaca, beberapa kalimat yang tidak konsisten penggunaannya, serta penggunaan tanda yang tidak lazim. Hasil transliterasi kemudian dilengkapi dengan anotasi, agar kata-kata yang sudah jarang digunakan atau kata-kata dalam bahasa Arab dapat mudah dipahami. Dalam melakukan suntingan, penulis berpedoman kepada Pedoman Umum Ejaan Bahasa Indonesia (PUEBI). 
Naskah pidato-pidato adat Minangkabau ini menjelaskan tentang pasambahan, pidato adat, syarat-syarat menjadi panghulu, palsapah pakaian panghulu, pembagian luhak nan tigo dan rantau nan duo, pembagian adat, hukum maisbatkan (menetapkan) sesuatu dan menapikan sesuatu, bajalan baiyo bakato bamulo. Sebagian besar isi naskah menjelaskan tentang pidato adat, yaitu sebanyak 18 buah pidato adat.

\section{REFERENSI}

Ahmad, Zahir dan Pramono. 2013. Beberapa Catatan Terhadap Kitab-Kitab Karya Ulama Minangkabau Pada Permulaan Abad XX. Laporan Penelitian. Padang: Jurnal Wacana Etnik

Baried, Siti Baroroh, dkk. 1994. Pengantar Filolgi. Yogyakarta: BPPF

Ekadjati, Edi S. 2000. Direktori Naskah Nusantara. Jakarta: YayasanObor Indonesia

Fathurahman, Oman, dkk. 2010. Filologi dan Islam Indonesia. Jakarta: PuslitbangLektur Keagamaan

Holander, J.j. De. 1984. Pedoman Bahasa dan Sastra Melayu. :PN Balai Pustaka

Moussay, Gerard. 1995. Dictionnaire Minangkabau Indonesian-Prancais. Paris: L'Harmattan

Mulyadi, Sri Wulan Rujiati. 1994. Kodikologi Melayu di Indonesia. Depok:Lembaran Sastra Universitas Indonesia

Navis, A.A. 1984. Alam Terkembang Jadi Guru. Jakarta: Grafiti Pers

Pramono. 2015. Wacana Maulid Nabi Di Minangkabau: Kajian Tentang Dinamikanya Berdasarkan Naskhah-Naskhah Karya Ulama Tempatan. Tesis. Kuala Lumpur: Akademi Pengkajian Melayu Univeristas Malaya

Putra, Yerri Satria. 2004. Transliterasi dan Analisis Teks Sejarah Ringkas Syaikh Paseban Assyatiari Rahimahulah Ta'ala. Skripsi. Padang: Fakultas Sastra Unand.

Rusmali, Marah, dkk. 1985. Kamus Minangkabau-Indonesia. Jakarta: Pusat Pembinaan dan Pengembangan BahasaDepartemen Pendidikan dan Kebudayaan Jakarta

Saydam. 2004. Kamus Lengkap Bahasa Minang. Padang: PPIM

Sudjiman, Panuti. 1995. Filologi Melayu. Jakarta: PT Dunia Pustaka Jaya.

Suryadi. 2004. Syair Sunur: Teks dan Konteks Otobiografi Seorang Ulama Minangkabau Abad ke-17. Padang: Citra Budaya Indonesia.

Susena, Danang. 2004. Dinamika Bahasa, Filologi, Sastra dan Budaya (Kenang-Kenangan Untuk Prof. Dr. Amir Hakim Usman). Padang: Andalas University Press

Yanti, Isma Darma. 2007. Transliterasi dan Analisis Teks Kitab Pertahanan Tarekat Naqsyabandiyah\|. Skripsi. Padang : Fakultas Sastra UniversitasAndalas.

Yusuf, M. 2017. Transliterasi dan Edisi Teks Hikayat Tuanku Nan Muda Pagaruyung Kaba Cindua Mato. Padang: Lembaga PengembanganTeknologi Informasi dan Komunikasi (LPTIK) Universitas Andalas 


\section{Trasliterasi Naskah Pidato-Pidato Adat Minangkabau}

\section{/1/Bismillahirrahmanirrahim}

(1) Kapalo pasambahan

Sambah anam

1. Sungguahpun iyo bakeh Sutan, diawa rundiang nan sapatah. Bakarapatan juolah Angku Pang(h)ulu nan gadang basa batuah. Nan cadiak nan tahu pandai, 
cadiak nan buliah bakeh baguru, tahu nan buliah bakeh batanyo. Aratinyo nan tiang alam sandi nagari, payuang panji ${ }_{1}$ luhak nan tigo, tali adaik batang limbago, tampuak alua tangkai pusako. Hulu aia pumpunan ${ }^{2}$ buluah, aia janiah tapian suji ${ }^{3}$, minuman kami di nagari. Nan maukun adil bakato bana, mamacik tarajo nan bagatok. Mamagang bingkai nan piawai, kapai tampek mangadu, kapulang tampekbatanyo. Manyukek cupak dengan gantang, manarangi cupak nan usali ${ }^{4}$.Mangadukan parik nan tarampa, sarato rancu nak lah lapuak, barih balabeh nak lah lipua.

2. Sungguahpun iyo sado itu, baiak guru-guru hambo lah surang jo duo. Aratinyo Alim jo Ulama/2/ nan tau bahadis baquran, nan manarangkan halal dengan haram, nan mambisukan sunah jo paralu, nan manyisiahkan sah dengan batil, nan maajakan kalimaik nan duo patah. Aratinyo suluah nan amaik tarang, palito nan tidak

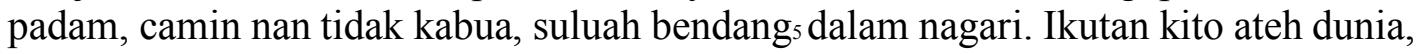
marawa basa di alam ko, madok kabakeh rang baniaik matika tampek rang bakaua.

3. Sungguahpun iyo nan sado itu, pilihan sakaji Hulubalang. Aratinyo nan dindiang paga parik nagari, kareh dindiang manangah koto, yo mati api dek Pang[h]ulu, kaki jo tangan di nagari, kaganti parik tanah batu, pahuni dusuntaratak.

4. Sungguahpun inyo nan sado itu, lapisan Manti jo Pagawai, urang nan cadiak candikio. Muluik manih bak pauah gulo, pandai manulih roman putuih, oleh panjang indak mangasan. Bahulu pendek indak mambuku, laweh babantang ka sabaliak, panjang nan indak katahubuang. Mato tarang, talingo nyariang, padoman taruih di nagari.

/3/ 5. Sungguahpun iyo nan sado itu, susunan anak baiak-baiak, sarato urang nan cadiak pandai. Aratinyo nan acang-acang dalam nagari, limpapeh ${ }^{6}$ rumah nan gadang, sumarak rono dalam kampuang, pimpinan koto jo nagari, buah catua Basajo Pang[h]ulu.

5. Sungguahpun iyo nan sado itu, baiak alek lah pulo surang baduo. Adiak kakak sanak saudaro, ipa jo bisan, nan di hilia nan di mudiak, nan saisi rumah gadang (Tanah Medan m-e-j-a-n-a-h i-y-p) nan di tapi tanah nak sabingkah, disangkuik awan nan sadidiah, sado nan di tapi lantai, nan diingkuang dindiang nan disungkuik atok. Tampek ambo mandatangkan sambah jo panitahan. Sambah

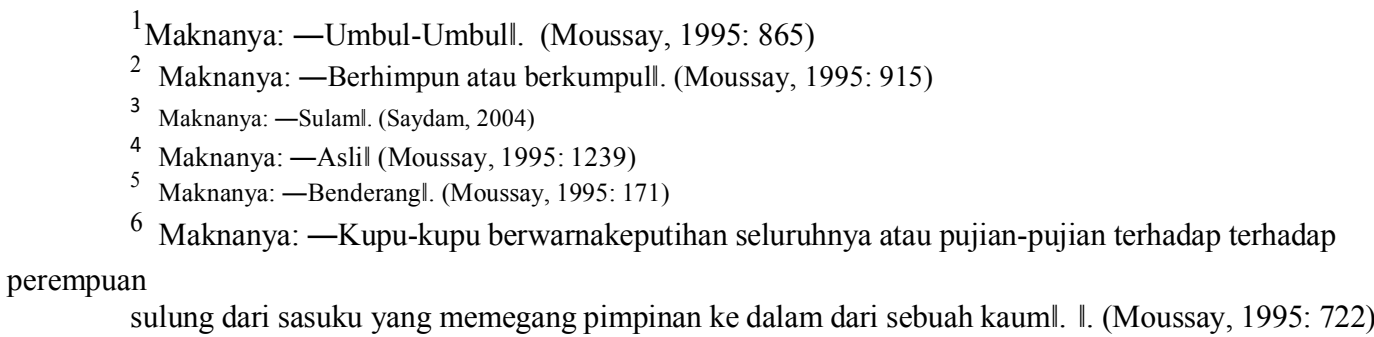


dipulangkan kabakeh Allah, panitahan kapado angku pang(h)ulu nan gadang basa batuah. Salam dikambalikan kabakeh sutan.

/4/ Kapalo Pasambahan

Sambah ampek

\section{Salam nan partamo}

Kapado Niniak Mamak hambo nan gadang basa batuah, sarato urang nan kaampek suku, pucuak bulek urek tunggang, tampek adaik tinggi pusako. Pai katampek rang batanyo, pulang ka tampek rang babarito, ka tampek malahiakan niaik, kabakeh malabuahkan kahandak. Duduak jo adaik jo pusako, tagak jo barih jo balabeh $^{7}$. Nan mamacik biang ${ }^{8}$ tabuak, nan mangganggam gantang putuih, nan tidak basisiah jo bahinggo, dalam himbauan kasamuanyo.

\section{Salam nan kaduo}

Kapado Tuanku dalam nagari, suatu alim nan baiman, nan pandaibahadih jo badalil. Duduak jo lapa jo maana, bapamainan sarak nan lazim, nan mamacik buku sariat, nan mamegang hukum kitab Allah, kalau mahukum samo adil, kalau mambagi samo banyak, nan tak buliah lewaik sapadi, bapantang kuduang sakundi, suluah bendang dalam nagari. Tahu diala dengan haram, manantukan sunah jo paralu, mampamahir mantik ${ }^{9}$ jo maani ${ }^{10}$, kok saraf $^{11}$ bak aia hilia, kok nahu ${ }^{12}$ bak mambilang dama, hukum fikih ancak sakali.

\section{/5/ 3. Salam nan katigo}

Kapado nan cadiak tahu pandai, aratinyo nan lubuak aka gudang bicaro, urang arif lagi disambah. Tahu dikarang nan manangguk, tahu dibayang kato sampai. Rundiang bakieh jo bajimek, nan tasuruak kabawah handai, nan tasirek batin nan dipacik. Tahu mambuhua tak mambuku, pandai mauleh takmangasan, kok duduak marawaik ranjau, kok tagak maninjau jarek. Pandai maatakmaetokan, tahu maagak maagiahkan, pakai adaik babatang pusako, kajadiragam bungo adaik, sabutan nan mudo-mudo. Bamusim di dalam tanah, batahun di dalam lunau, namun tareh mambangun juo, kok adok katangah lauik, nahkodo di dandang panjang, mandi batimbo aia masin, bagalah jo jari manih, badayuang jo tapak tangan.Pahamnyo bulek bak piluru, tenggang hilang barani mati, walau kok angok-angok ikan, buku cauak-cauak patuang, bapantang suruik satapak, haram

\footnotetext{
7 Maknanya:-Aturan atau ajaran-ajaran pokok yang dituangkan dalam pepatah dan patitihll. ॥. (Moussay $_{8} 1995: 121$ )

8 Maknanya:- Hampir Tembus, tembus pandangll. I. (Moussay, 1995: 174)

Maknanya: - Cara berpikir yang hanya berdasarkan pikiran belakall. (KBBI V Daring)

${ }^{10}$ Maknanya: - Secara leksikal kata adalah Maksud atau arti. Menurut istilah adalah ilmu yang mempelajari halihwallafazh atau kata bahasa Arab yang sesuai dengan tuntutan situasi dan kondisill (riungsastrawordpress.com)

${ }^{11}$ Maknanya: - Perubahan kata-katall. (KBBI V Daring)

${ }^{12}$ Maknanya: - Tata bahasa (menyangkut tata kalimat dan tata bentuk) (KBBI V Daring)
} 
lillah takana kampuang, kok tidak tacinto pamandian, tidak basimpang jo basapiah, dalam tuntutan kasamonyo.

\section{Salam nan ka ampek}

Adiak kakak ipa jo bisan, sarato dunsanak jo sudaro nan hadir di ateh rumah nangko, sado nan di tapi lantai nan dilingkuang dindiang, nan disangkuik atok, tampek hambo mendatangkan sambah jo panitahan. Sambah dipulangkan pado Allah, panitahan diparirikkan Niniak jo Mamak, salam dikambalikan Sutan sabagai silang nan bapangka karajo nan bapokok.

\section{/6/ Pidato Kumango ${ }^{13}$}

Buliah dipakai kamano yang dimaksud, didahului dengan kapalo pasambahan.

Adopun jalan duo nan dituruik, kato duo nan dipakai. Jalan nan duo, artamo nan lazim janyo sarak, kaduo nan kawi janyo adaik. Adopun nan lazim janyo sarak, hutang bapak kapado anak, hutang paralu di musajik di muko imamjo katik, badiri sasi dengan wali, dibaco pardu ain. Sarak tatumpah pado bapak, adaik tatunggang dimamaknyo, baitu nan lazim janyo sarak. Kato nan kawi janyo adaik, tajulai di korong kampuang, di ateh rumah jo tanggo, di muko niniak jo mamak, satu kaduo mako jadi, adaik nan basandi sarak, /7/ sarak nan basandi kitabullah. Adaik di Datuak Parpatiah nan Sabatang, undang di Datuak Katum angguangan, sadangkan warih Rasulullah, adaik balukih undang balimbago.

Di dalam adaik nan anam, ampek pulo baginyo, partamo adaik nan dipakai, kaduo undang nan dipilin, katigo pusako nan dirangkuah, kaampek limbago panyakah nan dituang. Jalan nan pasa nan dituruik, labuah nan asa nan ditampuah, sumua taganang nan disauak. Adopun panjadikan kato, anam baginyo, partamo cupak usali, kaduo cupak buatan, katigo kato pusako, kaampek katomupakaik, kalimo kato dahulu batapati, kaanam kato kudian kato bajadi. Itulah adaik nan tidak lapuak diujan nan tidak lakang dipaneh, kalo dibubuik ${ }^{14}$ inyo layu, kalo diasak ${ }^{15}$ inyo mati.

Kalau limbago anak laki-laki, duo sunaik dua paralu, tigo wajah dikanduangan. Dikato sunaik nan duo, bakikih baguntiang rambuik, dikato paralu nan duo, bapitah basunaik rasu. Adopun wajah nan tigo, partamo jadi pang(h)ulu, kaduo jadi imam, katigo jadi katik. Tumbuah dianak parampuan, duo sunaik tigo paralu, nan ampek sudahlah tarang, masuak kalimo basuami. /8/ Lai ketek dinanti gadang, lah gadang dinanti patuik, lah sampai bilang baraka, umua nan 15 tahun, lah patuik raso batompangan, bahutang ibu dengan bapak. Tahun bakurang kini

\footnotetext{
${ }^{13}$ Kumango adalah salah satu aliran silat di Minangkabau. Nama kumango diambil dari nama tempat diTanah Datar yaitu Nagari Kumango.

${ }^{14}$ Maknanya:-Cabutll. (Moussay, 1995: 196)

${ }^{15}$ Maknanya:-Alih, pindah, geserll. (Moussay, 1995: 92)
} 
nangko, kok hutang lah nak babayia, piutang lah nak batarimo, nan diniaik siangjo malam, nan dicinto patang jo pagi.

Disusun niaik nan tigo, nan wajib janyo aka, nan mustahil janyo aka, nan harus janyo aka. Kok kudaraik lah sahabih tulang, kok layak lah sahabih aka, mangaruaklah sahabih raso, manjambaulah sahabih tangan. Pueh-pueh dek mangapah, pasai-pasai dek mamilah, habih dayo baban talatak, tibo paham aka baranti, katolah putuih sandirinyo.

Adaik limbago urang barundiang, dipadok dipatidokan, dipaukua dipangkukan, lah hasil buhua balilik, barulah panjang dibari barueh, singkek dibari babuku. Dicari hari nan baiak, katiko nan elok, dibukak ujarat jo takwim ${ }^{16}$, dibilang katiko limo, dihituang galah salapan, dikambang sasonsong, runuik di dalam hari nan tujuah, dikanduang tahun nan duo lapiah lapiah. Ruponyo hari baiak katiko elok, nan sahari samalam iko kini, dikusai silang nan bapangka,baban barek nan bajujuang jinih bakarang nan tatapati, aratinyo karanolah.

\section{/9/Pidato Kawin \\ Didahului dengan pidato pasambahan}

Tatkalo maso dahuluyo, maso di rahim bundo kanduang. Baniaik ibu dengan bapak, kalau ado anak duo urang, surang anak laki laki, surang anak parampuan. Tumbuah dianak laki laki, duo sunaik duo paralu, tigo wajah dikanduangnyo. Dikato sunaik nan duo, bapitah basunaik rasu. Dikato paralu nan duo, bakikih baguntiang rambuik, adopun wajah nan tigo, partamo manjadi imam, kaduo manjadi katik, katigo manjadi pang(h)ulu.

Tumbuah dianak parampuan, tahutang ibu dengan bapak, hutang nan ampek parkaro, partamo dibaok turun, kaduo taurai rambuik, katigo batatah kakadi, kaampek mancari junjuang suaminyo. Sakaranglah ado anak parampuan, lai ketek dibaok turun, diaja makan dibaok mandi. Dibari bagumbak limau, bagumbak bagalang kaki, baganto bagiriang-giriang, kaganti ameh di puro ${ }^{17}$, kaganti sawah jo ladang.

Dibilang bilangkan hari, ditiok-tiok maso. Gadang nan duo baleh bulan, umua nan tujuah baleh tahun, lah patuik raso batompangan. Laki bak mamang urang tuo, luluak tarantang tak babaniah, anak marindu tak bajunjuangan, /10/ mako dicarikan junjuangan suaminyo, umpamo (ibaraik) urang taujuak. Jodoan subang jo talingo, jodoan jungkai jo kalingkiang, lah dapek junjuang suaminyo, kalau diuji samo merah, kalau ditahil samo barek. Surang adaik surang pusako, surang bulan surang mantari.

Adopun kamudian daripado itu, dipanggia niniak dengan mamak, ditanyokan barih jo balabeh, dipintak adaik jo pusako. Takanak barih di pang[h]ulu, baju takanak cupak dinan mudo, dibilang-bilang datuak, dirundiang dipapabana. Diurak si tambo lamo, diusai sampai pabanangan, diindang ditampi, dipiliah atah ciek ciek. Lah diapik adaik jo pusako, lah diapik cupak jo gantang, adaik lah pulang

\footnotetext{
16 Maknanya: -Penanggalanll. (Saydam, 2004)

${ }^{17}$ Maknanya: - Pundi-pundi, tempat uang terbuat dari kainll. (Saydam, 2004)
} 
kapusako, cupak lah pulang ka gantangnyo, gayuang lah suruik kabalabek. Katolah suruik dinan tuo, mangko dihiasi pulo rumah nan gadang, dibantangkan tabia langik-langik, tabia sakilek tanun juadah ${ }^{18}$.

Tirai batatah mutiaro, bakarang maniak bakuliling, barongga intan parmato. Langik langik baludu katiduan, tunggak bapaluik dengan cindai ${ }^{19}$, cindai halus panjang sambilan. Ditanun anak bayupani, haluih batangnyo tidak tantu, datang di pulau Malo Bari, pakiriman sutan di Palembang. Cindai pusako rang dahulu, dibantangkan lapiak parmadani, buatan anak urang Yaman, pakirin rajo dari Arab. Dibantangkan kasua madanggalo, /11/ batakut lagi batarawang, gambaran singo makan urang, buatan Puti Ranik Jintan, pakirin Sutan Saidi Rohib kapado baliau mandeh aciak ${ }^{20}$, diam dikoronng kampuang dalam, di rumah nan gadang nangko.

Ditarok kasua kadudukan, kasua pendek tindih batindih, dilampok dengan cindai haluih, diisi dengan lapiak saruang. Tatagak pulo sangga banta, bapucuak batulang bungo, dirakik banta pasandaran.Camin gadang silau manyilau, tampek kabasaran marapulai, lakik bakato ibaraik juo. Tadangalah pulo pakaian rumah, bak ujuang pulang baliak, mambayang sampai ka udaro, kamudian dari pado itu, diisi lancang nan kuniang, ditungkuih dengan kalam karih. Pandukuang duo kali anam, panungkuih duo baleh alai, kain palipek dinamokan, kain panjang lipek duobaleh, kain bajambo Rono Ali.

Lapang dibubuang si Barakaik, kampia didukuang si Baruliah. Pai manjapuik rang sumando, tibo di rumah marapulai, dimakan pinang sakapua, dipilin rokok sabatang, gayuang balangkah babalabek, tekong balukih batirawang. Jadinyo badalil bakatubah, tasabuik rundiang bahiyasi, dilagukan sambah manyambah, dimintak suko karilaan, lah buliah pinto jo kandak, dilakekkan pakaian marapulai, sarawa padinding aceh, bapucuak babanang mako, balukih jo aia ameh, baratuih camin di kaki, baribu camin di pinggang, kilek kumilau cahayonyo.

/12/ Baju baludu makan kuku, guntiang simabur siyalahan, tiru taladan limo kaum, rono ${ }^{21}$ camin makik gantai ameh, kasah ambun tatahnyo ijuak, buatan Japan tampek rumin. Di Aceh datang kulandan, di Cino datang panjahiik, deta palangi ragi minyak. Bapucuak bapatah tigo, tiok suduik tiok hikmaik, sisiak karih balam kainggok, lah sudah cukuik kasadonyo, lah turun marapulai, bapayuang mangiriang nan bajabatan.

Pedang tacabuik di hadapan, kipeh basabuang kiri kanan, dek lamo lambekdi jalan, lah tibo pulo marapulai, lakik bak kato ibaraik juo, dulang jo cangkia di halaman, tampek aia pambasuah kaki, ditabua dengan bareh kuniang. Lah naiak pulo marapulai, dilakekkan pakaian anak daro, kain palangi ragi kaciak, bakukuak ayam birugo, bakukuak di dalam padi. Tanun tarantang di sarugo, kain pengantin laki-laki;pengananll. (Saydam, 2004)

\footnotetext{
19

Maknanya: - Sutera yang berbunga-bungall. (Moussay, 1995: 257)

${ }^{20}$ Maknanya: - Panggilan yang biasanya kepada kakak atau bibi perempuan, atau kepada mamak yanglebih muda dari kita.l (Saydam, 2004)

${ }^{21}$ Maknanya: -Warnall. (Moussay, 1995: 967)
} 
lah sudah ka lamari. Tacancang lakik bungo abuak, bagaluik ganto ${ }^{22}$ di langan, mandariang buni ganto cincin, maningkah buni ganto galang.

Rumah nan gadang galok panuah, lah rapek imam jo katik, sato [p][u]lo alim jo pandito, langkok sahabih jo walinyo. Adaik limbago iko kini, manuruik alua jo patuik, pihak hidangan jo juadah, nan tahanta ka hadapan jamu, lah sudah langkok kasamuonyo. /13/ Sabuah tidak nan kurang, cukuik jo alaik pakakehnyo, talatak di ateh lapiak. Sadundun ${ }^{23}$ galeh jo cangkia, balimpah cipia jo piriang. Makan lah tibo dinan kanyang, minum lah tibo dinan sajuak, karano makan lah tibo dinan kanyang, minum lah tibo dinan sajuak, masuak lah apo nan dimukasuik.

\section{/14/ Pidato Siriah (1)}

Didahului dengan kapalo pasambahan

Kacimpuang ${ }^{24}$ pamenan mandi, rasian pamenan lalok, kurang tajajak tajalani, jo sambah sajo hambo atua. Laruiknyo kato dipanjangi, eloklah kato disampani, disampani sajo dengan sambah. Aratinyo nan bagala dipasambahan, siriah talatak di carano, elok nan bukan alang-alang. Siriah nyo udang tampu hari, tampuak nan bagai kuku balam. Tagarik gagak kahinggok, pucuaknyo coyong ka langik, ureknyo kalua ka bumi, rantiangnyo malangkah alam, bungonyo larang basuo. Buah nan kajadi katiruan, buah nan jadi katanaman.

Gagangnyo jawek bajawek, satahun dalam pagaluangan, samusin bapantang layua, usah kalayua tambah hiduik. Makanan anak rajo-rajo, sarato basa jo pang[h]ulu, talatak dalam carano, carano janja Reno Ali. Bakapuak babulan-bulan, batarawang bak ka Cino, loyangnyo kuniang mangaga, baru kawa dituangan, tuangan Agam Balai Gurah, buatan Sarik Sungai Pua. Dirauik dengan daun lamak, bapucuak babatang mako, batulih jo aia ameh, buatan anak Sandiang Baka, itu manjadi kabasaran.

/15/ Lorong kapado kapinangnyo, pinang nak urang Gunuang Rajo. Tumbuah di Padang kadataran, ureknyo selo baselo, batangnyo tinggi langgayuran, satahun upiahnyo rareh, samusin saludang jatuah. Buahnyo rampak bak kacubuang, putiah sakarek nampak hari, mako sarupo talua buruang, mambayang sampai ka udaro, mahadok ka mantari hiduik. Siang hari bak bulan panuah, malam bak bulan ampek baleh, nan tinggi jangkau-jangkauan, lah tuo tupai dek mamanjek, haram kok tibo dibuahnyo.

Pinang baluluak balah ampek, pinangnyo dasun ${ }^{25}$ balah duo. Pakirin

Sutan Mananggaliang, lauik sailian bakeh lalu, sambilan pulau bakeh sauh. Tibo di rumah si sudago, darek banamo Banda Padang. Kambuik ameh kadam ${ }^{26}$ suaso, kadam anak rang Koto Tangah, rampak bak bungo kacubuang, rimbun bak kalikihjantan, jalo nak tiwang ka tabang. Kapuanyo karang bajuntiah, samusin dipanggang hino, satahun dilingka bukih $\{\mathrm{k}\}$, dibasuah jo aia ambun, diturun jo

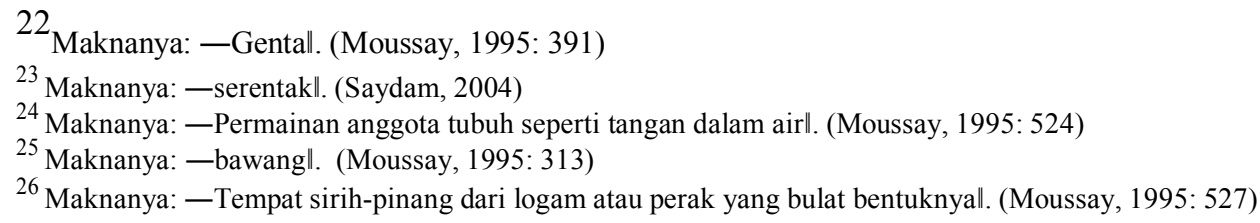


pati santan, dipalik jo jari manih, bakisa kajari tunjuak, mambayang katapaktangan. Sapalik $^{27}$ sapuluah ameh, sakadim sakali limo, dihago tidak tahago, dinilai tak pulo mungkin.

Gambianyo datang di Silamak, pucuak bacampua jo salabu, /16/ merah nan bukan alang-alang. Daunnyo arai mudo-mudo, ditanam di dalam parak, ditumbuakdi lasuang tinggi, halu kamuniang jolong sudah, gadih manumbuak jolong gadang. Disariang jo kain putiah, dikarasai jo kasiah ambun, tuangan perak baukia, buatan anak rang Payokumbuah. Timbagonyo si dini hari, banamo lumuik tarandam. Buahnyo si cupak rajo, bungonyo pano bidodari, tanaman anak Batu Taba, jangko buatan anak rang Guguak. Halus saukir nak rang kapado agakan batu bara aguang, buatan Sumpu Malalo, nan tidak masiak dipaneh, nan tidak lambok diujan, masiak barambun tangah malam.

Saheto panjang jaluanyo, sajangka dimakan api, sakijok baro tak padam, harun sarantau pajalanan, rantau mudiak padang diuni, pisang baharu naiak. Umbuiknyo putiah mudo-mudo, ditanam nak rang Ampalu, dilipek nak rang Tujuah Koto. Dijamu nak rang Pariangan, dijamu di tapi pantai, badabua ombak dari hulu, bahambuih angin di udaro, haluih bak sayok layang-layang, putiah bak kasiah biru ajih, lakik bak kato ibaraik nyo salin mangarang sakok, dikarangtangah halaman, kunyah siriah, pangganglah rokok, nak sanang hati sipangkalan.

\section{/17/ Pidato Siriah (2)}

Lakik papatah jo patitah, pantiang tasisiak jo hulunyo, di bawah Kiliran Taji, asa rundiangan di hulunyo tigo limbago nan tajadi. Partamo garak jo garik pamainan tangan dinan rami, kaduo sambah manyambah, sopan jo santun dalam adaik, katigo baso jo basi, banamo siriah jo pinang. Dek luruih tujuan bana, adaik kusuik cupak bapakai, tarang dikito nan basamo. Ulasan suri nan tagantuang, isinyo gantang nan tatagak, dalam naraco ba adaik. Banamo bangka nan panyawek, tasabuik bamuluik manih, tapakai babasao baiak. Muluik manih talampuang kato, baso baik gugu di bibia. Nan tidak lapuak dihujan, nan tidak lakang dipaneh, tiru taladan sampai kini.

Bamain ereang $^{28}$ jo gendeang ${ }^{29}$, batimbang baso jo basi, adaik bapakai salamonyo. Dek janji kato mufakaik, dek luruih tak buliah tidak, manuruik alua nan tigo. Tapi samantang pun baitu, limbago alek bapangka, talayang siriah ka tangah, talatak dalam carano tahanjo manenteang santun, bakandak adaik jo pusako. Kunyahlah siriah nan sacabiak, gatoklah pinang sadidieh, sambiakan gambia nan sabuah, palilikkan kapua nan sagantiak, sakian salam dipulangkan, diharap buni nak kambali.

/18/ Pidato Rumah Gadang (1)

Didahului jo kapalo pasambahan

\footnotetext{
${ }^{27}$ Maknanya: - Sedikitll. (Moussay, 1995: 1030)

${ }^{28}$ Maknanya: - Miring, condong, serongll. (Moussay, 1995: 354)

${ }^{29}$ Maknanya: -kecondonganll. (Saydam, 2004)
} 
Awa mulo rundiang disabuik, samo manyarah pado Allah, samo mangikuik kato bana. Allah taala kayo sungguah, Rasul Tuhan nan Muhammad, Pangulu kito sakalian alam, itulah nan cadiak tahu pandai, cadiak nan buliah bakeh baguru, tahu nan buliah bakeh batanyo. Nan duo barih nan duo langggam ${ }^{30}$,nan duo tigo persilaan, Kaampek kalimo m-w-a-t-l-b-t. Ahli nan saisi rumah iko, sado nan di tapi lantai, nan disangkuik atok, di lingkuang dindiang, dari ujuanglalu ka pangka, dari tangah lalu ka tapi, dari korong lalu ka haluan.

Rasian pamenan lalok, kacimpuang pamenan mandi, tidak tabilang taraok, sambah jo simpuah manjalani. Nan salingkuang rumah nan gadang, sabujua rumah nan panjang, tahantak lalu ka halaman. Nan saisi rumah nan gadang, rumahgadang surambi Aceh, salanca kudo balari, sabanta kubin malayang, salipuang karambia jatuah, sapakiak budak mahambua, sasajuak mato mamandang, sadingin anak badia.

Tiang panjang rajo badiri, tiang tangah puti barabuak pulang mandi, tiang tapi si Majo Lelo. Kampuang-kampuang /19/ si Majo Kayo pamungkang rajo sampono. Parannyo siula giriang, kasuatu bantang tujuan, lainyo perak baelo, intannyo bantang kumarau. Tuturan labah mangirok, atok singok alang babega, lapeh sakanda jaman talayang, panunjuak turak ${ }^{31}$ bulan tigo hari, kunjuangnyo sapagu intan, banamo rabuang mambacuik, gajah bajuang baju angku, musuahlalu padang tasentak, di ateh intan samparono.

Dindiangnyo dari Banda Cino, palupuah kasah tabantang, banduanyo sambah manyambah, janjangnyo si Punjuang Suri, di suok alang bamain, di kida ramo-ramo, di si busuak kumbang kumbang, banamo kumbang janti. Anak pamuncak di nagari nyato tapak an k-a-n-s-u balarek, halaman carano basah, urai tatabur indak ilang, raso kahilang gunduak atau kasiaknyo, lumuik bak ditantiang, batunyo, bulek bak digiliang.

Sanan karumu randah-randah, sinan piladang rambai anai, tampek si gadang main catua, tampek si budak main nundih, tampek nan pandai main kudo, elok kampuang bukan kapalang, baparik batanah batu, tanam baringin ririk payuang, tanam karambia atok tanggo, jaluang babatang-batang, pudiang ameh batamba jalan, raso katangkin dipangkasi, raso karandah dicuani, tampek mamandang dagang laku, dagang nan lalu hilia mudiak.

/20/ Labuah gadang manangah koto, pincuran mahadok pulang, aia janiah tapian suji, lumuik tidak latah pun tidak, elok disawuak kapaminun (kaminuman), indak lumuik tabao pulang. Bungo tanjuang di rusuak rumah, jatuah malayang salaruhnyo. Harun nan bukan alang-alang, harun sarento palairan, kamuning pautan kudo, limau manih sandaran alu, alunyo lai limau hantu, lasuangnyo baru jolong sudah, gadih manumbuak jolong gadang, ayam mangakeh jolong turun.

Rangkiang tujuah sajaja, salapan si Bayau-Bayau, sambilan si Tinjau Lauik, itu nan tinggi sakali, duo baleh anak tanggonyo, batiang basandi gadiang. Piriang balimb $\{\mathrm{p}\}$ ok jo sakaik, silang balukih jo mangkuto, dengan mangkutolipek kacang, tampaknyo alang kamanyemba, tampaknyo gajah kamanyorong. Kurang sadakek tak banyawo, mako digantakan pulo parhiasan rumah nan gadang,

\footnotetext{
30 Maknanya: -Gayall. (Moussay, 1995: 689)

${ }^{31}$ Maknanya: - Tabung kecil pada alat tenun yang berisi kumparan benang pakanll. (Moussay, 1995: 1214)
} 
janjang bapaluik dengan cindai ${ }^{32}$. Bandua bapaluik kain kuniang, tiang balamb $\{\mathrm{p}\} \mathrm{ok}$ jo sukat, mako dibantangkan pulo tabia langik-langik. Tabia takambang alun baralun, banta takanak susun basusun.

Kasua pendek tindih batindih, kasua panjang babantangan. Takambanglapik parmadani, ukia batindih suji basuji. Barangko intan dengan pudi, aka cino basaluk daun nyo /21/ rami. Pakirin sutan di nagari, baruliah kalifah dari salatan, Zulkarnain Iskandar, agak dipandang-pandang bana, umpamo sarugo ateh dunia. Adopun kamudian daripado itu, mako manitah juolah hambo, di bawah pangkek haribaan pangulu nan mamacik nagari, nan buliah limpah bendang kabasaran, nan mamacik tariang jo mantiko, nan mamegang anak bini si Rajo Awang. Jalannyo luruih, sifaiknyo kancang, sabateh nan dibilang-bilang, surek nan dibaco-baco, sabarih nan tidak hilang, satitiak nan tidak lupo, saparti dalil nan mangato; ikuikdikamu akan Allah, ikut dikamu akan Rasul, dengan urang nan mamacik pekerjaan.

Tagak badiri di haluan, duduak di karisi Samburani. Intan di kiri rukuk bapalangi, di kanan cahayo nan manikam, tangan talayok hukun jatuah. Kaki talangkah kato sudah, kalam tacayiang jadi tambo, kalo bakato rajo-rajo saparti dalil nan mangato; jikalau bakato rajo, adolah kato baliau itu, sapartiguruahdengan patuih. Kilek nan tapijam-pijam, indak t-t-n tatangadah, oleh sagalo ragihnyo, oleh baliau itu.

/22/ Lampisan daripado itu, mako diuraikan pulolah jalan nan duo. Suah jalan karano Allah, kaduo jalan karano dunia. Adopun jalan karano Allah, asa agamo dari Allah disampaikan melalui Rasul, mako didirikan nagari nan ampek parkaro. Partamo Makah, kaduo Madinah, Katigo Baitul Makdis, kaampek Baitul Hujarat. Mako didirikan Imam nan barampek. Partamo Imam Safii, kaduo Imam Hambali, katigo Imam Hanafi, kaampek Imam Maliki. Artinyo imam nan barampek tu suluah bendang di dalam alam, palito Arab dengan ajam, ikutan kito umat islam. Itulah imam nan tinggi, cahayo Makah jo Madinah. Ikutan umaik Rasulullah, mamakaikan sariaik daripado Allah. Siang dan malam barhati lillah, kapado bagindo Nilam Manilam, telah manarangi sakalian alam, limbago telah lauik jo daratan, berkat karunia daripado Tuhan.

Tatkalo itulah mako dikato iman, islam, tauhid, makrifat, mako dikarajokan pulo rukun nan limo. Partamo sahadat, kaduo sumbayang, katigopuaso, kaampek bazakaik, kalimo naiak haji ateh kuaso. Adopun jalan karano dunia, bamulo harato bando, anak dan isteri, janjang dan latiah, galang dan taruko,perhiasan di ateh dunia.

/23/ Adopun sambah hambo maliputi kapado imam jo katik, sarato alim jo pandito, sarato Bila jo Malano. Sarapeknyolah pakanah jo pakawi, sakalian pilihan hulubalang, nan lalok siang bajago malam, nan baruliah kalipah dari TuankuBagindo Ali, parik ronjong manangah koto. Simpang sapatah dalam nagari, mambarikan harimau galak c-ng-k-z-h, nan manangadahnyo ka langik-langik, nan manungkuik ka bumi. Kuaik nan bukan alang-alang, barani nan tidak mintakkawan.

\footnotetext{
${ }^{32}$ Maknanya: - Sutera yang berbunga-bungall. (Moussay, 1995: 257)
} 
Rajo dibari badaulat, pang]ulu dibari bahandiko, tuangku dibari badarajat, hulubalang dibari basifat, rajo kok tidak badaulat bak bulan tacampuang siang. Pangulu kok tidak bahandiko bak bulan dilangkok raun, tuanku kok tidak badarajat, palito nyalo siang. Hulubalang kok tidak basipaik, bak payuang tabubuik pasak, sambah ditagukan hinggo itu. Masuaklah kapado nan dimukasuik,umpamo mintak diri dan lain sabagainyo.

\section{/24/ Pidato Rumah Gadang (2) \\ Kapalo Pasambahan Sabagai Biaso}

Adopun jalan duo nan dituruik. Partamo jalan ka akhiraik, kaduo jalan karano dunia, adopun jalan ka akhiraik seperti firman nan mangato; Waati'ullahawa ati'ur rasula,ikuik dikamu akan Allah dan ikuik dikamu akan Rasul. Dituruiksuruah dihantikan tagah, dipakai sarat dengan rukun, dikaji sah dengan bata, dipabisukan hala dengan haram, dikaji sunaik jo pardu, dikarajokan amal jo ibadah, diucapkan kalimaik nan duo patah.

Adopun jalan kapado dunia, bamulo harato bando, anak dan bini, perhiasan di ateh dunia. Adopun dunia duo parkaro, partamo langik, kaduo bumi. Adopun parhiasan langik ampek parkaro, partamo bulan, kaduo mantari, katigo bintang, kaampek timur jo salatan. Perhiasan bumi ampek pulo parkaro, partamo lauik, kaduo tumbuah-tumbuahan, katigo r-w-m-w-t si jumbai anai, kaampek koto jo nagari.

Adopun perhiasan koto jo nagari, partamo balai jo musajik, kaduo labuahjo tapian, katigo medan nan suni, kaampek kampuang jo halaman, kalimo rumahjo /25/ rangkiang. Iyolah rumah tigo saing, rumah banamu katigonyo, di pangka Gajah Maharam, di tangah Rajo Babandiang, di ujuang Sarambi, di ujuang surambi Aceh, Aceh banamo Minangkabau.

Takalo asamulonyo, dipatah rantiang salayo saludang jatuah ka banda. Takalo kamanabang kayu, kayu banamo aduan basa, tumbuah di pantaikalerengan. Tumbuh di lantai pinggang bukik, urek manyapu pungguang limbu, pucuak malambai awan putiah, buah manjadi pauah h-p-k-y, makanan hiyu jo karatang, tareh binuang jo b-sw-y, tareh candano kayu ereang. Tumbuah dijirek Balai Kamba, kayu batuah janyo urang

Di Guguak gunuang bagombak, di Bukik Salasiah Hitam, tareh tahunjam ka lautan. Sungkur di lingka nago sati, ula bagaluang di ureknyo, taduang ${ }^{33}$ bakutat di dahannyo. Alang babega di pucuaknyo, pucuak manyapu awan hijau. Kulik banamo kulik lawang, baniro randaman ula bidai ${ }^{34}$, rantiang manjadi ula giriang, buah manjadi buah palo, bungo manjadi bungo cengkeh, adopun rabahnyo kayu nantun, indiko rabah di loyang. Saguguak timbunan bahan, sagudang timbunan basi, tatagak apa di rampunyo. Indaknyo rabah kayu nantun, tumbuah pikiran urang tukang, dipanggang kumayan putiah, disauak pangkanyo

\footnotetext{
${ }^{33}$ Maknanya: - Nama ayam sabungan yang berbulu merah tua, kaki dan matanya hitam. (Moussay, 1995: $)^{34}$ Ula Bidai menurut kepercayaan orang, ular itu seperti bidai terhampar, siapa yang duduk di atasnya digulungnya. (Moussay, 1995: 1114)
} 
bakuliliang, disaru Allah jo Muhammad, /26/ mamintak bakeh nan kabuliah, bakandak bakeh nan balaku.

Takdir Allah sakutiko, kandaknyo sadang kabuliah, pintaknyo sadang kabalaku. Batiup pulo badai garik, bapusiang cando halimbubu, galab gulito tangah padang, guruah kamano pandangaran. Badantam buni patuih tungga, mangkonyo rabah kayu nantun, kayu hiriang banuang sati, tampek taduang bakualo, tampaik upa $^{35}$ barulang makan, tampaik hiyu bakuruang diam, tampaik jihin bamain catua, sananlah ikan mati dingin.

Sampailah rabah kayu nantun, disaru pulo urang tukang, urang darek Minangkabau, ajaran tukang Siak Ulai, warih dek Jati Bilang Pandai, tahu mambarih mambalakang, tidua bagantuang bak si landik, lah ta $\{\mathrm{i}\} \mathrm{bu}\{\mathrm{o}\}$ pulo urang tukang, langko[k] jo alaik pakakehnyo, sarato kapak jo baliyuang, kapaknan dari Banda Padang. Haluih mato tajam mamutuih awang-awang. Baliyuang dari Bangkahulu, buatan anak rang Inggirih, pakirin rajo si Ulando. Katam nan dari tanah Jawo, buatan anak garagasi.

Lah cukuik alaik jo pakakeh, mako dicari hari nan baiak katiko nan elok, dibukak hujarat jo takwim, dihituang katiko limo, dibilang galah salapan, di dalam bulan nan duo baleh, dikanduang hari nan tujuah. /27/ Mangko digabuang tiang nan panjang, nanamo si Maharajo Lelo, panjang duo puluh heto Arab. Dibuekalua duo baleh, alua badia Malelo Japun, tiang banamo kasamunyo, tiang panjang si Maharajo Lelo, tiang tangah si Maharajo Ali, manda g-n-ng lapan, tiang tapi Puti baririk pulang mandi. Tiang tigo karo bajuntai, si tandeh mati pareso si Katatan dagang manumpang, kasayangan urang di nagari, baiak baso elok parangai, pumpunan anak mudo-mudo, pamenan rumah nan gadang.

Pamenggang rajo kuaso, panca manti barulang, pasak si layang-layang mandi, hujan satahun tidak basah, mangko dibari dinamoi rumah nan gadang. Rumah gadang surambi Aceh, tiang panjang si Maharajo Lelo, tiang tangah si Maharajo Ali. Nan lanjang di lauik lapeh, nan jambang di Pulau Paco, mangkuto urang di nagari, tiang tangah si Maharajo Ali Mandagiliang, mantido lapan, sumarak jirong kampuang dalam, tiang tapi Puti baririk pulang mandi. Tiang tigo karo bajuntai, si tandeh manti pareso, dagang manumpang si Katatan, kasayangan urang di nagari, baik baso elok parangai, humpunan anak mudo-mudo, pamenan rumah nan gadang, pamenggang rajo kuaso.

Ramo-ramo di susuak kambang, nan sukur alek tibo, nan santun dianak dagang, tapatan larek bakualo, patuik baliau jadi kali, tungganai rumah nan gadang. Dampa dandam tajelo, galak tasanyum dituturan, patuiklah jadi juru baso, panagur ipa pasumandan. Paran gadang si ula giring, /28/ kasaunyo si ula landai, paran tinggi tupai managun, managun di pangka turak, sajak baliau naiak gadang, nagari basusuk rami, anak buah banyak nan santun, camin tarus rumah nan gadang. Takalo rumah kabasandi batu balansing dirajonyo, tanah banamo tanah jati, kasandi rumah nan gadang, sadikik pulo nan kadipuji. Ibu kayo bapak batuah, anak nan cantik banyo padi, sumangaik rumah nan gadang.

Lakik sasak tarawang caci, lakik lahir intan takarang, kanak atok awan bajampo di awang-awang. Jikok babaur jo nan pandai, kapeh saancik jadi banang,

\footnotetext{
35 tempat ular yang amat bisa. (Moussay, 1995: 1235)
} 
patuiklah pulo jadi guru, camin tarus di rumah nan gadang, lakik s-k n-ng-k-y-l-y-ng lapeh. Ereang gendeang si rangkak lari, manangguak lembang makan, dipanggil luhak jo lareh, dapeklah koto jo nagari, lah patuik niat disampaikan.

Singoknyo alang babega, tuturun labah mangirok, tuduangnyo tanduakkabau jalang, sajak ketek masak pangaja, urang baik aturan elok, nangkodo rumah nan gadang, dindingnyo rajo nan pendek, camin tarus namo pintunyo, tampak mamandang tiok hari, salisih adaik jo tarang, datang p-l-t-h maukunnyo. Bumi sanang padi manjadi, banduanyo ula mangalapik, mangampai lalu ka muaro, ikua malingka panantu gabak, nan tuo nan jadi pandai, pandai mambilang barusuak pawang rumah nan gadang.

/29/ Lambai-lambai rajo manuruik, golong pantiang rajo manjabau di bawah pagu, tampak nan dari pintu gabang, nan tuo kabakeh suruik, kapai tampek batanyo, kapulang bakeh mangadu, Tuan Kali rumah nan gadang. Lah sudahbangkawan ${ }^{36}$ rumah, dipanggia pulo tukang ukia, anak rang darek Minangkabau. Ajaran tukang sibak ulai, warih dek Jati Bilang Pandai, pandai mufakaik manarawang, maukia sambia balari, marapek dibulan kalam, manjanang ${ }^{37}$ dibulantarang.

Lah tibo pulo tukang ukia, langkok jo alaik pakakehnyo, cukuik jo paek layang-layang, dikandakkan ukia babagai ragam, aleh bagarak tukang ukia, sadangkan paek babuni, duo tigo papan nan sudah. Lakik ukia babagai raga, bak baradu bajanang basadah langgam, batulih jo aia ameh, babintang babukan-bukan, tasalabuang bamato hari, aka canonyo bajan tangan.

Salampin lapih balapih, tajam balek ereang gendeang, ukia gambaran bungo cengkeh. Pucuak rabuang salo manyalo, kaluak paku jangkau bajangkau. Baukia hati bahati, bacukia badama ${ }^{38}$ tirih, b-t-n-t-d-w basaluak laka, b-k-y-w-ng baula giring, basulam bakalam karih. Bapangka babungo karang, babungo sari manjadi, badaun baharai a-m-w-n, m-b-w-1 batampuak manggih, baliyuang sakapih cino, batarawang batulih sagarik, galuik bagaluik anak ukia, bagai kaluang baliak tidua, b-t-k-t basaluak alai.

Ukia banamo kanamonyo, aka banamo aka cino, kaluak banamo kaluak paku, pucuak banamo pucuak rabuang, daunnyo kasuntiang puti /30/ b-w-l banamo Cinto Manih, saluak banamo saluak laka. S-l-m-p-t lapeh jarami, tantadu itiak pulang patang, lakiklah kato ibaraiknyo. Ukia banamo aka cino, cino banamocino karam. Banyaklah rajo nan takato surang saliman ka pucuak banamo pucuak rabuang, rabuang banamo rabuang aua, tumbuah di parat $\{\mathrm{k}\}$ pasupadan, aua banamo aua jungkai. Bahimpun burak jo buruang, ayam jo alang campua baua, sadikik haram basalahan, m-ny-m-h s-l-y-m-n jo balukih.

Kaluak banamo kaluak paku, paku banamo paku aji, bapesong angin jo limbubu $^{39}$, kandaran b-m-n batang pakai, ukia perak janannyo ameh. Daun timbago aso-aso, tiok buah tiok kamati, dalam buah ado parindu, tiok daun ado

\footnotetext{
${ }^{36}$ Maknanya: - bilah buluh yang digunakan sebagai tulang atap nipah atau rumbiall. (Moussay, 1995: 139)

${ }^{37}$ Janang adalah tiang tempat dipasang pintu. (Moussay, 1995: 490)

${ }^{38}$ Dama adalah nama beberapa jenis pohon yang menghasilkan getah. (Moussay, 1995: 293)

${ }^{39}$ Pusaran angin (Moussay, 1995: 722)
} 
pamanih. Ukia manggilo buruang tabang, makanan anak bidodari, lakik namonyo tiok jorong. Nan suduik mayang tahurai, di surambi simpai bakaja, di ujuang hilang balaia, di pangka tepi bagalut, ukia banamo sabuk aia, lakik lah katobaratinyo, dapeklah banang Malo Pari, sajangka tingka dari tangan, garik pado jo limpakai, ukir sudah tukanglah mati, nan tingga jadi pandapatan, tak buliah diulang lai. Satalah itu hambo punyo sambah. Kamudian masuaklah kapado nan dimukasuik.

/32/Pidato Mangatangahkan Hidangan (1)

Sasudah Kapalo Pasambahan

Sungguahpun iyo kapado Sutan salam dipulangkan. Sarapinyolah Angku Pangulu nan gadang basa batuah, nan duo barih kadudukan, dalam sariaik jo hakikaik. Nan salarek sababandiang, b-b-s-w satanding sajamba makan. Salanggam bandua di tangah, takapuang ka tiang panjang, lalu ka tapi tiang sudah,tibo disandi alua adaik sampai kalutang parapatan. Tinggi tabayang nampak jauah, randah barubuak tampak dakek, tahu dikilek dengan bayang, tahu dikieh kato putuih, tahu dicakar dengan kaik, tahu disambang langkah kida, tahu dikilek kato habih. Nan bamain di Ujuang Padang, malangkah di pangka karih, nan basilek di ujuang muluik, panitahan kapado isi jamu.

Ujuang salam kabakeh Sutan, adaik kato nan kadipasambahkan, diadaik nan janiah, dicupak nan papek, digantang nan duo baleh. Bajalan lambek baanyok, bakaja capek di hulu, talayang sampai ka tangah, babalun-balun jo buih, riak mamacah kiri kanan. Haluan mambaok jauah, ombak mambaok ka tapi, ombak batamu jo galombang, riak batamu jo daburan, aia tasawuak di saludang, aratinyo ka gunuang edaran kabuik, ka luran timbunan batang, ka bukik samo mandaki ka lurah samo manurun. Barih nak samo kabapaek, /33/ takuak nak samo kabatabang, aka manjulai bungo t-b-w-w, bungo nak samo dipasuntiang. Umpamo urang kabatunangan, suatu tabantang dengan banang, barih balabeh nan dilanjuakan,ukua jo jangko nan lah sudah. Turuik nak mamintak, sakalian salam dipulangkan, diharap buni nak kambali.

/34/ Pidato Mangatangahkan Hidangan (2)

Sasudah Kapalo Pasambahan

Namun baitu nyo lai kini, takah iyo dek dirahik ${ }^{40}$ dunia, asuhan budi nan manangko, basaua batando jadi. Paham nan lungga-lungga arek, rumik batenggang samo surang, nyato senjang bajaman garah, bak buah ranun di ujuang, dihambo tagak tak sampai, dijuluak galah talampau. Lah mabuak dikiro-kiro, lalu dituruik dihampiri, kiro-kiro bapakai arek, dalam arek bapakai kuek. Suliklah paham maratehnyo, takah dek luruih batujuan, sariaik adaik nan bapakai, nyato pusako baungkiran. Usah maluak mausaki, elok di dalam janji mulia, dilangkuangbukik nan bakarang.

${ }^{40}$ Maknanya: -Raib, tidak kelihatanll. (Moussay, 1995: 928) 
Langgam adok baagiah tumbuah, ganggang baampang limo, tumbuah sarupo iko kini. Dek niak sapanjang hari, dek naza sapanjang jalan, niaik tapandam lah bamusin, habih hari babilang hari, habih tahun roman batuka. Hakikaiklah mambayang kailimu, marupo batin kanan lahia, sampai tabatiak tabarito, lah asa siang bak hari, lah nyato tarang bak bulan, dilahia batin nan batinjau, dunia sakiro paguruan, banamu dunia mudo-mudo. Adaik mambimbiang di baliaknyo, manuruik lazim nan dipakai, sariaik aluran cinto, /35/ hunjuak biaso babarikan, agiah biaso batarimu, lembak nan daripado itu.

Manuruik timbangan kami, pandang jauah lah dilayangkan, pandang hampia lah ditukiakan, pihak dihambo nan talatak. Basusun baruang tangah, baririk di ruang tapi, sadundun galeh jo cangkia, sarato dulang tuduang aia. Barisi juadah jo makanan, banamu ragam bungo adaik, namun bakato nyo lai kini,hidangan sudah k-r-h-n-y kini lah tibo di hadapan Angku. Tarik aia basuhlah tangan, naknyo salamaik sampuruno, tanggungan Angku nan basamu, pulangmaklum bakeh Angku, diharap buni nak kambali.

\section{/36/ Pidato Alam Pendek \\ Sasudah kapalo pasambahan}

Tatkalo maso dahulunyo, mangko bapikialah niniak kito nan batigo. Dipandang utaro jo salatan, mamandang ka barat timur jati, mangko balaialah ka dalam lauik. Antah barapolah lamonyo di dalam lauik, di dalam lauik baharullah. Balaianyo katigonyo, tampak gunuang dikanduang kabuik, dihampia lauik sailan tinggi manyapu awan putiah, Gunuang Adam urang namokan, di situ Adam batampek mulo. Adam turun ka dunia, dima baranti di sinan mukasuik lah balainlain, pikiran lah bamasiang-masiang. Dih $\{1\}$ ingong kiri jo kanan, dipandang hilia jo mudiak, tampak gunuang barawan-awan, mahasok cando apinyo. Mako balaialah niniak kito ka pulau Ameh, pulau Andaleh Muaro Siak, Gunuang Marapiakan namonyo.

Alah sahari duo hari, tujuah hari lamo di sinan, duduak diajun ${ }^{41}$ kiro-kiro,

tagak diganjua palangkahan, dilihek kiri jo kanan, dipandang hilia jo mudiak. Di kiri Gunuang Parpati, di kanan Talago Merah, bapakai urek talang parindu, tampek siburuang liya mati. Malihek hambo pun tidak, kaba urang hambo kabakan, di pohon campako biru, bapakai urek talang basurek. /38/ Disurek anak Indo Jati, pagaran rumah nan dipertuan, di ujuang campako merah, di tapian Puti Sibiru Alam, puti nan turun di kayangan, akan jodoan rajo kito.

Takalo maso dahulunyo, rajo batigo badunsanak, Puti batigo basudaro. Dikawinkan oleh malaikaik, Rajo batigo naik Nubah, nan surang ka Banuruhun, nan surang ka Banu Cino, nan surang balaia ka pulau Ameh. Diam di ranah Panjaringan. Di balai bal[a]iruang panjang, sinan lah rangik rang bunian, di rusuak baringin sunsang, sinan sampaian ula bidi. Sirangkak nan hitam kuku, buayo nan putiah daguak, sinanlah ruso balang kandi, tanduak ameh jipak suaso. Bulu sakalatIndo b$n-t$, ruso pamenan Puti Runduk di balai baliruang panjang,

\footnotetext{
${ }^{41}$ Maknanya: “Dimaksudkan”. (Moussay, 1995: 20)
} 
baatok ijuak anau putiah, tumbuah sarumpun tigo batang, sinan lah naniang ${ }^{42}$ jo tabuhan.

Tampek labah baduyun diam, sinan jalatang nan batareh, aka lundang 43 saluak basaluk. Dipuluik-puluik nan sabatang, Saliguri basimpang tujuh, sinan harimau balang kandi, tampek tanggaluang hutan lapeh. Dipohon kalapo niur gadiang, tinggi manyapu awan putiah, urek manyapu pinggang lambu, kok tumbuah masomasonyo, duo bulan ampek baleh, tampat rambau barulang diam.Di baruah padang panarian, tampek bamain /38/ Indo Jati. Pado katiko hari patang,bakeh nan mudo main catua, tampek pandeka main pedang. Masuaklah kapado nandimukasuik.

/39/ Pidato Mangatangahkan Adaik(1)

Sasudah kapalo pasambahan

Salam nan kadipulangkan kabakeh Sutan, ruponyo dikami silang nan bapangka, karajo nan bapokok. Lah tibo malang nan taraiah, mujua nan tatulak, lah bapulang baliau karahmatullah, lah dibungkuih jo kapan nan barasiah. Dihantakan basamo-samo ka pintu kubua, baliau dimasuakan ka dalam lahaik nan amaik sunyi, dibacoan doa dek Tuangku. Kok buliah pinto jo kandak, hiduik juolah baliau sabulan duo bulan lai, satahun duo tahun lai. Sapainak dapek baiyo batido dek anak buah baliau, karano baliau angko urang budiman bijaksano, lauik aka padang bicaro, katampaek duduak mangadu, tagak bamulah dianak buahbaliau. Tumbuah sarupo iko kini.

\section{Indak buliah sakampik padi sakambuik ditumbuak luluah Indak buliah duo nan kandak hati kandak Allah hanyo nan sungguah.}

Dawaik kariang kalam lah patah, karateh baguluang hanyo lai. Kalo adaik islam mati, dilacuikan tabuah, dibunikan buni-bunian, dilatuihan badia malelo buatan Japun, ratak maleko ka ujuangnyo. Kok bana dari awak, kok salah datang dari urang. Alun dipatiak lah /40/ malatuih, alun disunu ${ }^{44}$ lah badaciang, adang manjadi karih pendek, sampai ka kampuang dipanggangyo.

Tembak rang tanah Simalangkang, pandai mambilang rueh tabu, tahu manungkek anak janjang. Samangkir-mangkir rang manembak, dibaliak gunuang kanai juo, tapi samantang pun baitu lakik jolah bak handai kato bidaran.

Ramu-ramu sikumbang jatikatik

Endah pulang bakudo

Patah tumbuah hilang samo kito mancari pusako lamo nakjan binaso

\footnotetext{
${ }^{42}$ Maknanya: - Sejenis labah yang bersarang dalam tanahll. (Marah, 1985: 197)

${ }^{43}$ Maknanya: - Nama tumbuhan yang air akarnya dapat dipakai untuk obat tetes matall. (Saydam, 2004)

${ }^{44}$ Maknanya: - Membakar dengan suluh atau punting berapi.l (Saydam, 2004)
} 
Namun baitu hanyo lai kini, karano patah kaditumbuahkan, hilang kadiganti, tantu adaik tarantang kadipakai, cupak tatagak kadiisi, limbago tasakah kadituang. Kok barih hutang mamahek, kok tagok hutang manabang, pihak di carano nan ka tangah, tak balihek balengong diangku, kok indak dibarih pahek makan, kok indak ditakuak tabang tabubu. Maklum pulang bakeh Sutan, diharap buni nak kambali.

\section{/41/ Pidato Mangatangahkan Adaik (2)}

Sajak alek samulo jadi, sajak hitam samerah kuku. Hukum arek sudah dipagang, umanaik sudah dipaciak, sampai ka lauik ka daratan. Ka ranah luhak nan tigo, dilangkuang lareh nan duo. Lah kawi adaik di nagari, lah lazim sarak di alam, pusako di korong kampuang, agamo diranji kito. Hadis tatulih dalam kitab, firman takato di quran, di sinan dapek tali taguah, kito bagantuang lahia batin.

Ragi paham dalam tubuah, paham insaf paham nan haniang. Paham mambaok lalai, paham s-a-k barisi antah, yakni ilmu tagak, ujudlah disatukan, pangana lah dibantangkan, diagak agak dipikiri, pikir itu palito hati, tanang sarugoaka, dalam sungguah bana mandatang, namun baitu nyo lai kini. Kalo salorongnan bak kini, alah bamakam banasabah, limbago tajunlah dituang, adaik tarantang lah dipakai, pintak jo pinto dilakukan. Pihak di carano nan ka tangah, panuah konyo malimbak, korong koto tuo badagok, nak dalam timbangan Sutan.

\section{/42/ Pidato Alam Pendek Mandirikan Panghulu}

Sasudah Kapalo Pasambahan

Sungguah pun kapado Sutan salam dipulangkan, sarapeknyolah Angku Pangulu kami nan kaampek (kalimu) suku. Pucuak bulek urek tunggang, sarato Manti jo pakawi, Hulubalang jo ampek limo, sarato urang dalam nagari. Sahinggo barih nan tatagak, sahinggo jurang tabulantang, sado nan dilangkuang halua patuik. Adopun salam nan kadipulangkan kabakeh Sutan, bak handai kato bidaran, tumbuah sarupo iko kini, mulo dilacuik Padang Panjang, adaik limbago lah takambang, nyato pusako lah tajulai, isinyo barih jo balabeh, basamo kito mamakaikan. Sajak naza jo nan usali, sampai sakarang kini nangko, adaik pidato basambahan.

Rasian pamenan lalok, kacimpuang pamenan mandi, baiak kato rundiang nan elok, adaik limbago lah tajalai. Lah sudah janjang pahatok, lah patah mako dikamba, sukutan bukan alang-alang. Lah sanang di dalam hati, sakato kito nan basamo. Dibilang-bilang, dihatu-hatu, dicuri dapek bana, ciek pun tidak buliah hilang, sampai dibuhua mati-mati, dibukak si tambo lamo, tujuan kato bayau pari, turun ka tanggo naiak ka janjang, rundiang nan buliah basuligi.

/43/ Warih nan sajak dahulunyo, sariaik adaik nan bapakai, mulonyo adaik kabadiri di Pariangan Padang nan Panjang. Tuah ${ }^{45}$ sakato dek mamakai, mufakaik lah sudah di hulunyo, lah kambang ka Minangkabau, asanyo adaik bapakai,

45 Maknanya: “Kehormatan, kemuliaan”. (Moussay, 1995: 1195) 
dengan papatah patitahnyo, sajak dirajo nan dahulu, limpahan anak nan batigo. Putuih kato habih rundiangan, hilang di lauik tumbuah di daraik, ado papatah maso itu;

\author{
Di mano titah palito \\ di baliak tiluang nan barapiDi \\ mano asa Niniak kito \\ di puncak Gunuang Barapi.
}

Basentak turun ka bawah, lah tibo di Guguak Ampang, di langgundi nan baselo. Dalam di kampuang Pariangan, lalu ka ranah Minangkabau, banamo rajo nan usali. Asanyo Luhak Tanah Data, babatu bungo satangkai, basungai bakayu tarok, bakampuang di baliak labuah, nan banamu dusun tuo. Balimau di sinan, batabek basawah tangah, nan dibaok niniak kito, Datuak Tantajo Kurahano, nan mahatua sambia duduak, nan manurak sambia tagak. Sawah gadang satampang baniah, makanan urang tigo luhak. Aia satitiak dalam pinang, sinan bamain ikan arinyo, baitu warih nan dijawek, itulah tutua nan didanga, basabuik jo sampai kini.

Ujuang labuah Tanjuang Sungayang di dalam Luhak Tanah Data, duo baleh koto di sinan. Babasa baampek balai, badaulaik yang dipertuan, /44/ Tuan Kali di Padang Gantiang, Indomo di Saruaso, titah di Sungai Tarab, DatuakMangkudun di Sumaniak, Tuan Gadang di Batipuah, Rajo Basa di Pagaruyuang. Itulah urang nan mamarintah ka dalam luhak nan tigo, lareh nan duo.

Kaduo luhak Lubuak Agam, nan sahinggo Lado Suluah Mudiak, sahinggo Dasun Tungga Hilia, salilik Gunuang Barapi, salingkuang Gunuan g Singgalang. Katigo Luhak Limo Puluah, aia janiah ikannyo jinak, hinggo si Sauah Sungai Rimbang, hinggo Silukah Pinang Tinggi. Hinggo Durian Ditakuak Rajo, hinggo Pisang-Pisang Hanyuik. Di dalamnyo luhak dengan lareh, sarato ranah dengan hulu. Balimu rajo di Sinan, nan banamo m-y-k adaik. Bajanjang ka Ladang Laweh,bapintu ka Sungai Patai, tumpangan Datuak Maudun, nagari salamaik samparuno.

Cukuik jo adaik jo pusako, langkok jo barih jo balabeh, utang dek kito mamakaikan, nan dinamui Kubuang Tigo Baleh, sahinggo Singkarak Sandiang Baka, s-r-y-t-n kayu marunduak, k-s-z jo Sumani, kumur kaciak jo kumur gadang, Hulu am-ng jo batung Guguak. Sampai salingka Gunuang Talang, yaitu ka Taluak ka Tanjuang Paku, Tandikek Padang Kalundai, manurun ka Solok kaSilayo sampai ranah Koto Baru, /45/ Gauang jo Panyakalan, Kinari, Muaro paneh, Cupak jo Gantung Jirek Koto Anau jo Limau Langkok, Talang Talago diadok sampai ka Guguak si Jawi-Jawi, itulah nan banamu Kubuang Tigo Baleh.

Masuak ka luhak Tanah Data, kalo lareh nan bajanjang naiak, partamo Koto Piliang. Nan babarih nan bapaek, nan baukuran nan bakabuang, coreang barih buliah dilihek, cupak panuh gantang bahujuang. Kaduo Bodi Caniago

Kalo tuah dinan sakato isinyo

rundiang dimufakatiDi lahia

lah samo nyato

di batin samo dilihati. 
Nan kato iyo baitu, manuruik pitua niniak kito; nak rajo ka dalam alam, maisi ka dalam alam, nak batuah masuak nagari, jan takuik bahabih ameh, asah santoso awa akir, baitu barih nan bapaek, itulah ukua nan bakabung, sajak samulo dahulunyo, sampai kini baitu juo. Sambah ditagun hinggo itu, dipinta r-d-y-d-ng naknyo singkek, nan bak panyato urang tuo; kok ketek dibari banamo,gadangdibari bagala. Kini dibari banamo, utang dek ibu dengan bapo, gadang mambaribagala.

Di nagari nan bapang[h]ulu, di kampuang nan batuo, di rumah nan batungganai, tumbuh sarupo iko kini. Lakik bak papatah kato adaik, bak patitah cupak gantang;

\section{Ramu-ramu si kumbang jati \\ /46/ Katik Endah pulang bakudo \\ Patah tumbuah hilang basamo kito mancari \\ Pusako lamo nakjan binaso}

nan si p-w-1-p dahulunyo, kini digalai Datuak Manjinjiang Alam, tagak jo adaik jo pusako, dibarih cubak jo gantang, nan dibaok hilia sarangkuah dayuang, mudiak nan sahentaan galah, sambah tatenggang dinan banyak, diharap buni nak kambali.

\section{/47/ Pidato Alam Pendek}

\section{Sasudah Kapalo Pasambahan}

Kato papatah jo patitah, papatah Datuak Katumangguangan, masuak di ateh balai balairuang panjang, kapado anak Minangkabau nan saisi dunia nangko, lalu Makah ka Madinah, hanyo sadikik tidak nan labiah, basaketek tidak nan kurang, kok kurang ado labiahnyo, kok labiah ado kurangnyo. Sababnyo mangko baitu, karano dek niniak kito nan baduo, partamo Datuak Parpatih Nan Sabatang, kaduo Datuak Katumangguangan. Iyolah nan banamo Lareh nan duo, partamo Lareh Koto Piliang, kaduo Lareh Bodi Caniago.

Adopun kabasaran Lareh Koto Piliang, bapamuncak aindomo, Batuan Kali barajo-rajo, basutan-sutan, bacamin tarus, baharimau campo. Manaruah pasak kungkuang jalujur m-m-p-y-y pasemaian Batu Patah, manaruah lareh nan panjang sahinggo Bukik Tambusu Batupang Mudiak, nan sahinggo Guguak Sakaladi Hilia, itulah nan banamo lareh nan panjang. Adopun kabasaran Bodi Caniago, tuahnyo dinan sapakaik, cilakonyo dinan basilang. Tatapi apabilo handak mufakaik Datuak baduo itu, digantuangkan tangkai dikalikan di dalam. Tidak lapuak dihujan, tidak lakang dipaneh.

/48/ Adopun kabasaran Koto Piliang, barajo-rajo apabilo handak manyusun larehnyo, mufakaik Datuak nan batigo, yaitu Datuak Bandaharo, DatukIndomo, Tuan Kali. Di atehnyo daulaik nan dipertuan, mangko dinamoilah kabasaran Lareh Koto Piliang. Pamuncak alam di Sungai Tarab, payuang panji di Saruaso, suluah bendang di Padang Gantiang, camin taruih di Singkarak SandiangBaka. Harimau campo di Batipuah, tinggi adaik di Pariangan Padang Panjang, pasak kungkuang jalujur di Sungai Jambu, rajo basa di Bukik Batu Patah. Adopun 
Lareh Bodi Caniago, hampun yang maha mulia oleh daulat nan dipertuan, mangko nagari batungkuik dunia takambang.

Kamudian daripado itu, mufakaik Datuak Katumangguangan jo Datuak Parpatiah Nan Sabatang di ateh balai balairu[a]ng panjang, dipandang awa aro jo Utaro, mangko mamandang ka Baraik Timur Jati, balaia ka dalam lauik, antaro lauik Siambang ombak. Antah barapolah lamonyo, lah m-y-w di pulau pisang, batamu tuan putih bandaro sati, cukuik jo bana tantaranyo, sarato alaik sanjatonyo. Lalu baranti lah di sanan, kapa basauah hanyo lai, lalu baparanglah di sanan, sampai sahari duo hari, sampai babulan lah lamonyo, kalahlah kafir si Ulando, ulando pulang ka nagari.

Parpatiah nan Sabatang duo jo Katumangguangan, babaliak pulang kadaratan. /49/ Takalo maso dahulunyo, balun batiku Pariaman, balun basunua Kurai Taji, balun batubuah Pakandangan, balun basintuak Lubuk Alung, ditinggakan anak dayangdayang, nan surang anak laki-laki, nan surang anakparampuan, kamahukun dibatang rantau, iko nan banda nan sapuluh, asa nantingga hanyo urang.

Kamudian mangko kambali Datuak Parpatih sarato Datuak Katumangguangan, ka balai balairu[a]ng panjang, manurun ka Padang Panjamuran, di bawah tataran nago sati, kabungo si suntiang alai, malereangsagalo kandak, lah tibo di Pagaruyuang, masuak di dalam Pagaruyuang. Batigorajo saangkatan, barampek basa naiak balai, balimo dengan Tuan Gadang. Sapiah budi balahan adaik, masuak di dalam Pariangan, diagiah luhak jo lareh, diagiah rantau jo darek. Ka rantau ka batang hari, ka Siak ka Singapalan, sabalah mantari hiduik, sajak dijunjuang Sungai Ngiang, sampai ka Ranah Sikaladi. Talang uleh batu basurek, batang asai Pangkalan Jambu, ka Cingkuang Lubuak Ramo-Ramo, lapeh ka Kuok ka Bangkinang.

Hukuman Sutan Rajo Mudo, sajak di Luhak Tanah Data sampai ka Agam ka Batipuah, batagak batu palano, ka Sariak ka Sungai Pua, ka Canduang ka Koto Laweh. Hilia ka Rantau Lubuk Aluang, lalu Jirok /50/ Banda Padang, taruih ka Banda nan Sapuluah sampai ka ranah Indo Puro. Masuak parintah daulaik yang dipertuan, lah dibagi luhak jo lareh, lah diagih koto jo nagari, sahinggo Sabuak Andaleh hilia hinggo Guguak Batu Taba Mudiak, banamo Sapuluah Koto Hilia.

Diagiah tando surang-surang, tandonyo luhak barajo, tandonyo lareh bajunjuang, tando nagari bapang[h]ulu. Sajak di Gunuang Panujuan, sampai ka Jaho ka Tambangan, banamo urang ampek koto, itulah urang nan sapikua ringan nan samo dijinjiang. Singgalang jo Panyalaian, Koto Baru jo Aia Angek, Pandai Sikek jo Koto Laweh, banamo urang anak koto, urang Ampek Koto jo AnamKoto, banamo Sapuluh Koto di mudiak.

/51/ Pidato Alam Untuk Mandirikan Panghulu Didahului Kapalo Pasambahan

Sungguahpun bakeh Datuak dipohonkan sambah, mako dimintak juolah ampun dan maaf dihadapan Datuak Pang(h)ulu hambo urang limo suku. Sungguah pun iyo nan sado itu, bakarapatan juolah Pang(h)ulu hambo nan sapuluah janiah, sungguhpun iyo nan sado itu, bakarapatan juolah Pang(h)ulu 
hambo nan tiok-tiok lareh, nan sahinggo Sabu Andaleh Hilia sahinggo Guguak Batu Taba Mudiak, yaitu nan saisi lareh Batipuah Sapuluah Koto, nan tanamo Batipuah Sapuluah Balai, tampaik hambo mandatangkan sambah jo panitahan.

Yakni nan bagala nan dipasambahkan, adopun hambo nangko kiro-kiro balun bajalan, aka budi jauah sakali, sungguahpun iyo nan sado itu, sarato dunsanak jo sudaro, ipa bisan adiak jo kakak, hinggo riak badabua mudik sahinggo Gunuang Marapi malintang hilia, salilik Gunuang Marapi, saedaran Gunuang Singgalang, salingka Gunuang Pasaman. Sahinggo Pisau-Pisau hanyuik, hinggo Sibayangbayang hilia, hinggo Taratak Batu Hitam, sahinggo Tanjuang Samalidu sahinggo Durian di Takuak Rajo. Lantak sapadan rajo mudo dengan daulat sah alam, /52/ Maruhun basa ampek balai, sumarak reno Tanjuang Bungo, hulu jantuang limpo bakuruang, lubuak hati tapian mato, santiang pamenan bundo kanduang.

Mangkuto Alam pulau Paco, ka Johor lalu Kapatanai, Kalimnun ka Batang Asai, Ka Arab ka Batu Mesir ka Ruhun ka Batu Cino, ka Makah lalu ka Madinah, ka Aceh ka Korong Dalam, ka Kudum ka Balai jangko, k-b-w-z ka Sumpur Kudusnan barajo badaulaik, s-l-h itu hambo punyo sambah. Tabukak di hati nan suci, tarabik di muko nan janiah. Gayuang balangkah babalabek. Tukang balukih batiruan, kato disabuik bahiasi, pinang-pinang di ateh bukik, salodang jatuah ka lambah, dibao nak rang Bangka Hulu, nak lalu ka Muko-Muko, nak singgah ka Indo Giri. Tanangtanang Angku sadikit, hampunan jolong manyambah, ayam bakukuak imbau ragu, murai bakicau hambo lupo.

Kononlah kabasaran nan duduak iko, ka gunuang ka sikalibuik, ka hulu ka rimbo jati, kayu gadang banyak babuah, sarumpun jo kayu gamaik, ragulah hambo kamanyabuik, pang(h)ulu banyak nan sati, rang gadang banyak nan batuah, tuanku banyak nan kiramaik. Kiramaik itu tigo parkaro, partamo kiramaik ilimu, kaduo kiramaik tuah, katigo kiramaik aka, adopun kiramaik ilimu, hiduik kabakeh rang baniaik, /53/ mati rang bagaua, mati ka tampek rang bagaua. Adopun nan kiramaik tuah, tali kail panjang sajangka, lauik nan dalam didugonyo, dan katigo kiramaik aka, tali kail panjang sapuluah, lauik sailan diujuaknyo, itulah nan kiramaik aka.

Kayu sapik madang di lurah, ditarik katangkai pangukua, labiahnyo kapapan tanduak, kabek nan harek ta[k] baruyah, samapai nan tagok tak baransua. Sakarang kini ado juo, jahik bajahik tapi kasua, suji ba suji saruang banta, bakalo rahik aso, buliah diliek pado asa. Yakni takalo maso dahulunyo, uleh dirajo nan batigo, partamo Sutan Maharaja Alif, kaduo Sutan Maharajo Dipang, katigo SutanMaharajo dirajo, mako termashurlah rajo Iskandar Zulkarnain pado langik, t-r-s- m-b-w-y-l-h pado bumi. Mako handak balairlah rajo nan batigo, dibuaek parahu satu buah, antaro mansarat jo pasirat, antaro Timur jo Salatan.

Dilingong kiri jo kanan, dipandang hilia jo mudiak, lautan tanang bak lantak, air sarupo camin mudo. Langik lah mandaun pauah, tampaklah pulauLanggopuri, balaia lalu ka sanan. Alah sahari duo hari, tigo hari lamo di sanan, tibo malah silang jo salisiah, oleh dirajo nan batigo, mangkuto tanduak ameh, /54/ silang siapo kamaukuan, cakak siapo kamaleraian, awak nan rajo katigonyo. Turun surang malaikaik, diambiaknyo Mangkuto Tanduak Ameh, dibanamkannyo 
masuak lauik, alah dipaluik ula bidai, alah dilingka nago sati, banderang ka langik cahayonyo, sakarang kini ado juo.

Alah barakah maso di sanan, nan surang ka Banuruhun, nan surang ka Batu Cino, nan surang balair ka pulau Paco. Duduak bamanuang surang diri,dicari Jati bilang pandai, nan mano ko jo ujuang tunjuak, nan balandasan dengan lutuik, dicari karando satu buah, diisikan tukang di dalam, maniru Mangkuto Tanduak Ameh, Mangkuto sudah tukang lah mati, tak buliah ditiru lai. Masuaknyo Allah manggarakkan, datang kiamaik maso itu, kiamaik nabi Nuh janyo urang. Habih sagalo isi alam, tingga sabuah parahu, dinamoi Pasirat Barat. Pulau Andaleh Muaro Siak, Gunuang Marapi akan namonyo.

Alah sahari duo hari, tujuah hari lamo di sanan, lauik lah mahitam turun, tampaklah pulo puncuk bapunjuk, tampaklah gunuang jaram manjaram, bukik lah $<\ldots>$ tidua. Tagak di awan nan babilai, duduak di pintu liwang gunuang, mancaliak inyo ka hilia, tampaklah karang nan manjujuk, tambang urai sungainyo ameh, lantai batu bapakai ruyuang, /55/ ranah banamo Sikalawi, kampuang banamo Bukik Gumbak, malengong inyo ka mudiak, tampaklah tanjuang mamutuih, taluk baliku batu hampa, ranah banamo Silimpauang, kampung banamo Tanjuang Alam.

Dilingong kiri jo kanan, di kanan Gunuang Parpati, di kiri Talago Merah,di ujuang si Tinjau Lauik, di rusuak Pincuran Tujuah, dipaga urek talang parindu, tampaik si buruang lia mati. Di kanan campako merah, di rusuak nan basurek, disurek anak Indo Jati, pagaran rumah yang panyatuan. Dikiri cimpako biru, di tapian Puti Sainur Alam, Puti Jamilah janyo urang, mandi batampuk kasai. Duduak dianjo kirokiro, tagak diganjua palangkahan.

Dingin hari bukan kapalang, dek takuik manahan dingin, manurun kabaruah nangko, mako manurunlah niniak kito ka bukik si ganting-ganting, banamo lantak panjariangan, katai gunuang Patok Alo, sinan kalundai nan baselo. Sinan dadak Silabu labu, sinan sumua dikalo mandi, di hilia aia kamarinjang, di rusuak batu nan barayun, sinan Sirangkak nan badangkuang, Sirangkak hitam putiah kuku, sinan buayo putiah daguak.

Di rusuak balai bal[a]iruang panjang, balai buatan Datuak Kurahano, nan batungkek tareh jalatang, nan babanda batang /56/ bayam, nan baparan aka landak, nan batabuah puluik-puluik, nan bakandang saliguri, nan batataran saka jintan. Inolah balai nan tidak lapuak dihujan tidak lakang dipaneh, di ujuang balai pasujian, di pohon balai saruang. Di sinan lah Datuak kito mambilang Luhak jo Lareh, mahetong Koto jo Nagari, manampuak lareh nan duo.

Partamo lareh Koto Piliang, kaduo lareh Bodi Caniago, didirikan rajo jo rang gadang itulah tarajo nan bagatok. Diangkek basa jo pang[h]ulu, itulah bangka panyaui[k], tak buliah dipaliang lai, didirikan basa jo pangulu itulah karih tambalan padang, bak tubuah jo bayang-bayang. Ibaraik sakit jo tajamnyo, didirikan manti jo pakawi, umpamo kaki dengan tangan, pandai mauleh tak mambuko, tahu mambuhua tak mangasan, mako dinamoi Luhak Nan Tigo. Partamo Luhak Tanah Data, kaduo Luhak Lubuk Agam, Katigo Luhak Limo Puluah, sahinggo Tanjuang Alam Hilia, nan banamo Luhak Lubuak Agam, sahinggo Tungga Hilia, sahinggo Lado sulah mudiak, nan banamo Luhak Limo Puluah, sahinggo dasun tungga hilia, sahinggo aia baulak mudiak. /57/ Luhak 
Tanah Data batanjung tigo, di hilia Tanjuang Kalawi, di mudiak Ranah Tanjung Alam, di tangah Tanjuang Sungayang.

Limo Kaum Duo Baleh Koto, Sungai Tarab Salapan Batu, Batipuah Sapuluah Balai. Mufakaik lareh nan duo, sarato luhak nan tigo, rajo mufakaik jorong gadang, basa mufakaik jo pang[h]ulu, Manti mufakaik jo pagawai. Didirikan basa barampek, pancari silang jo salisiah, paukun kato nan tak putus. Pandai mangganang aia lauik, mauji samuik dalam batu, suluah bendang dalam kampuang. Camin tarang dek nagari, palito basa dek pang[h]ulu, didirikan palimo hulubalang. Kaganti paruik tanah batu, pamaga koto jo nagari, pahuni dusun jo taratak.

Rumah adaik dibagi tigo, bahanjuang piliang di Tanah Data, surambi papek di Luhak Agam, $<\ldots>$ di Limo Puluah. Angkatan dibagi tigo, deta bagamak di Tanah Data, deta sabalik di Luhak Agama, deta bakaruik di Limo Puluah. Alek jamu dibagi tigo, larak lirik di Tanah Data, alek jamu di Luhak Agam, janjang $<\ldots>$ di Limo Puluah. Takalo sumua dikali, asanyo rantiang dipatah, tandonyo adaik kabapakai. Di balai balairu[a]ng panjang, nagari babilang sarago. Basuku babuah paruik, kampuang bamamak tabaonyo.

/58/ Kamudian dari pado itu, mangko balaia Datuak Parpatiah sarato Datuak Katumangguangan, mandapek ka Pulau Pisang, banamo anak si Ulando. Lah parang maso di sanan, Alah sahari duo hari, lah tujuah hari lah lamonyo, lah suko raso di Baganjau, lah sayup raso dimansainyo. Lah baranti parang maso itu, mako kambalilah Datuak Parpatiah sarato Datuak Katumangguangan. Ditinggakananak dayang-dayang, surang anak laki-laki, surang anak parampaun. Kajadi rajo dibatang ransau. Ikutan bandanak sapuluah, asa nan tingga janyo urang.

Mangko kambalilah Datuak Parpatiah, duo jo Datuak Katumangguangan, ka Balai balairu[a]ng Panjang. Manurun ka Padang Panari<..>, di bawah Padang Panjamuran, di rusuak baringin sunsang, di bawah tataran nago. Tibo dibungo nan satangkai, malereng ka Galo kandang, lalu Kudam Balai Jangko, sampai ka Ranah Pagaruyuang, masuak di dalam Pagaruyuang. Batigo rajo saangkatan, barampek basa naiak balai, balimo dengan Tuan Gadang, sapiah jurai balahan adaik, masuakdi dalam Pariangan, bakeh luhak jo lareh, diagiah rantau jo darek, ka rantau ka batang hari, ka Siak ka Singapalan, sabalah mantari hidup. Sajak di tanjung Sungai Ngiang, sampai ka ranah Sikalawi. Talang Uleh Batu basurek, Batang AsaiPanggalah Jambu <..> lubuak ramo-ramo, lalu k-k-w-z-h ka Bangkinang. Ka salo aia tirih, lalu ka ranah ka Rumbio, hukuman /59/ Sutan Rajo Mudo.

Sajak di Luhak Tanah Data sampai ka Agam ka Batipuah, ka Sariak ka Sungai Pua, batagak batu palano, ka Canduang ka Koto Laweh, hilia ka rantau Lubuak Aluang, ka Toboh ka Pakandangan, ka Tiku ka Pariaman, sampai kaJirong Banda Padang. Sapanjang banda nan sapuluah, lapeh ka ranah Indo Puro, hukuman dulah yang dipertuan. Lah diagiah Luhak jo Lareh, lah diagih Koto jo Nagari, hinggo Sabu Andaleh Hilia, hinggo Guguak Batu Taba Mudiak. Banamo Sapuluah Koto, diagiah tando surang-surang, tandonyo luhak barajo, tandonyo lareh bajunjuang, tando nagari bapucuak, mako t-w itulah hambo punyo sambah. 
Kalo hiduik dikandung dunia, ibaraik pulai bapangkek naiak, maadokan rueh dengan buku, manyusun dahan dengan rantiang, manaruah buah denganbungo. Kalo manusia nan batanggo turun, mamakaikan adaik jo pusako,mambaokan cupak jo gantang. Saabih nan dibilang-bilang, surek nan dibaco- baco,sabarih tidaknyo hilang, satitiak tidak nyo lupo, nan babarih babalabeh. Nan babaju nan bapakai, nan basasok bajarami, bapandam bapakuburan, bajanjang naiak batanggo turun. Anak Sutan pandai mambilang, pandai mambilang baru aso,

/60/ ujuan hanyo nan hilang, pusako baitu juo.Lah mati udang di gu <..> salah mamegang sapiknyo. Lah mati baliau nan tuo, nan matah mamegang warihnyo, lai sarik dinanti talang?, kapohon sambia ka hilianyo.

Lai kaciak dinanti gadang, maukun ko tidak adil, lakeklah rantai kini-kini. Dimakan sumpah Parpatiah, kayu gadang di dalam banda, pilinlah aka katalinyo, urang kok tido bana, pintu narako manantinyo. Dimano kalapung nan babuah, babuah di dalam padi, lah hilang baliau nan batuah, lah baganti jo nan mudo kini. Ramoramo Sikumbang jati, katik endah pulang bakudo, patah tumbuah basamo kito mancari, pusako lamo nak jan binaso. Tumbuah sarupo iko kini, kok patah lahnak manumbuhi, kok hilang lah nak diganti, di dalam itu limbago tasakah lah dituang. Cupak tatagak lah diisi, kok barih hutang mamahek, kok takok utang manabang.

Namun baitu nyo lai kini, lai si pulan dahulunyo, digalai Datukmanjinjiang alam. Tagak jo adaik jo pusako, dibarih cupak jo gantang nak dibaok hilir nak sarangkuah dayuang, mudiak nak sahantakan galah. Gala nan mintak dihambaukan, di labuah nan rami di pasa nan guluang. Sakian sambahdipulangkan, diharap buni nak kambali.

/61/ Pidato alam pendek

Untuak mandirikan pangulu didahului dengan kapalo pasambahan

Yakni takalo maso dahulunyo, dikalo gunuang kamancigok, lauik lah mamintak suruik, langiklah marinjiang naiak, bumilah mahantam turun. Dunia tadantang nak barisi, alun malatuih alam dunia, kok sumua balun basawuak, kok rantiang balun bapatah, mako turunlah urang dipuncak gunuang. Iyolah baliau nan basangko patah, nan baliyuang sumbiang, nan batunggak batareh jilatang, nan baparan aka landak, nan babandua bayam (batang), nan balapiak daun hilalang, nan batataran saka jintan, nan manarah jo manyiang mansai, iyolah baliau Datuak Suri Tantajo Kurahano, tangkai nan panjang duo baleh.

Sialah urang warih nan kamanjawek, pusako nan kamanolong, iyolah baliau Datuak Suri Bandaro dalam Nagari Pariangan, Padang Panjang. Alam batambah leba juo, umaik batukuak tambah juo, taluak jo liku lah barisi, tanjuang jo bayang lah bauni, alah malatuih ateh dunia, kok sumua alah basauk, kokrantiang alah bapatah, bapangkek masuak singok pandai bakato, balun balelobatampaik, balun balaku baparangai, urang barajodi hatinyo, urang basutan dimatonyo.

Takalo maso dahulunyo, tanah mulo pulau Andaleh dalam alam Palembang Barat, nan banamo hambo sambah kan, angku, tuan, datuk. Adopun kamudian daripado itu, mako bakatolah Puti Saknibah, -Manolah 
Katumangguangan, anyo lai ketek mudo matah, kok darah /62/ satampuak pinang, kok umua satahun jaguang, jan duduak tacangang sajo, jan tagak bamanuang surang, mamintak bakeh nan kabuliah, bagaul bakeh nan karamaik. II Mangkomanyaru lah Katumangguangan - Ya Allah, ya Tuhan Yarabbal alamin, berkah Mekah jo Madinah, barakaik Kabbah tiang langik Allah, kok lai usali anak rajo, kok lai basunduik anak puti,\| takdir Allah sakutiko, kandak sadang kabuliah,pintak sadang kabalaku, sadangnyo hampia pado Allah, mako turunlah Puti Saklain Saklani di Luhak Minangkabau, karanah ka lantai batu, kandatinyo dilantai batu, nak dapek lawan baiyo, nak buliah lawan babukan, tatampeh kabadan surang, kok tagak sajo, kok duduak bamanuang surang, duduak di ateh bano rajo.

Bahambuih angin timur Jati, manyenga paneh si kukadok, takantuak talaloklalok, di bawah ka tapiang pantai, dalam lalok datanglah mimpi, datang karamaik nan batigo, mako bakatolah kiramaik nan batigo - Manolah Puti Saiklani s-y-l-n-y, pailah angkau balaia, balaia ka tanah Aceh, kapado rajo parampuan, mintak patunjuk jo pangaji, mintak lah pulo alaik dunia. Mintaklah banang sailiak, kadiungkan di dalam dunia. Mintaklah adad jo ma'dud.\| Warih nak buliah kadijawek, pusako nak buliah kadirangkuah, buliah sagalo anaknyo cucu, lah buliah nan sado itu, mako balaia pulo malah /63/ ka Luhak ka Minangkabau. Balaia jo lapiak pendek, malereang ka ujuang Arab, lah tibo di pulau baiak, Pulau Sagantang Lado Katiak, mako mancaliak Puti Saiklani s-y-l-n-y, tampaklah pulo pucuak-bapucuk, gunuang lah jaram manjaram, bukiklah mangabua tidua.

Ka Gaduik lalu ka Patani, ka ambun lalu ka Utaro, kabalaku ka kancah basi, mamutuih lalu kasampulan. Lah tibo di pulau Panjang, tampak Andaleh baruah bukik, tampaklah Tanjuang Sungai Ngiang. Mako manurun ka lantai batu, balun lai kaji kadisabuik, balun lai timbo disangkuik. Tuhan Allah mentakadirkan, mako lahialah Parpatiah Nan Sabatang, nago sati bakisa tidua, ula giring manyisih riak. Umbai-umbai mamasa jalan, si k-w-m-b-y pulang mamarun.

Alai b-c-y manabua bijo, d-w-a-t-w mambari tawa, malereai marapak baso. Mantari rundiang si Kurano, bulan balun bapakai bintang, bintang, bintang timur balun lai tabik, bintang tanjung balun lai tampak.

Kini lamo basarang lembak, gadanglah Parpatih nan sabatang, gadang bak diambuih-ambuih, gadang sarubah samalam. Alah pandai inyo bapikir, pandai bahadih jo badalil, tahu <..> bama'ani, banyak mangaji kitab Allah. Sarak lah dilazimkannyo, adaik lah dikawikannyo, nan ala lah dialakan, nan haram alah diharamkan, mako diucapkan kalimat nan duo patah, AsyhaduAllah Illah halillah, /64/Waashaduanna Muhamadarasulullah ${ }^{46}$. Kok Rasul kulipah Allah, kok Rajo kulipah Nabi, mako diadokan rajo di dalam alam Minangkabau. Kamamarintah alam nan laweh, diangkek Pangulu dalam nagari, kamamarintah dalam Nagari. Elok alam dirajonyo, elok Nagari dipang[h]ulu, elok kampuang Datuaknyo, elok rumah di tungganai, elok labuah dinan rapek, elok tapian dinan mudo. Aia janiah tapian suji, Puti Baririk Pulang Mandi, rajo batandan samo rajo, sutan saririang samo sutan. Puti batambang dalam dalam tapian. Rumah jo lambuang pun lah ado,

\footnotetext{
${ }^{46}$ Maknanya "tiada Tuhan selain Allah, dan aku bersaksi bahwa Nabi Muhammad adalah utusan Allah".
} 
balai musajik lah badiri, itulah warih nan kito jawek, amanaik nan kito pegang, pusako nan kito rangkuah.

Kok nak mulia tapeki janji, kato bana dipacik taguah, tidak buliah diingkari. Rundiang sapatah nan dipegang, kato sabuah nan diganggam, kalo nan luruih kato bana, tidak lah buliah diubahi, itu nan kato sabananyo, manurut adaik jo sarak. Ado pun kato adaik, gantang di Bodi Caniago, cupak di Koto Piliang. Dunia habih kiamaik tibo, labuah luruih jalan basimpang. Limbago jalan tampuh juo, itu karajo niniak mamak, sarugo dek iman taguah, narako dek laku awak, sajak samulo dahulunyo, sampai kini baitu juo, lah k-w dipanjangkan, eloklah kato disampani, mako disampani jo sambah t-n ha dst masuak kapado nan dimukasuik.

/65/ Pidato Mintak Doa yang Meninggal

Kapalo Pasambahan sakadarnyo

Adopun limbago hiduik di ateh dunia, tiok-tiok nan bapantang biaso patah, nan batampuak biaso layua, nan bamato samiang, nan banyao maraso salilik ngilu paniang, labiahnyo mati di atehnyo. Samaso insan batampek dengan nyawo, buruang batampek dengan talua, nyawo batampek dalam badan, manangguang sakik ngilu paniang, sarato mati di atehnyo.

Adopun limbago kito mati, dilangkapi dengan kalangkapannyo, anduk-anduk nan amaik leba, sarato pakan nan barasiah, cukuik jo cawan timbo mandi. Urang kampuang datang manyanguak, nan mudo-mudo datang mahusuang, tumbuah sarupo iko kini. Karano bilangan nan alah cukuik, ukua jo jangko nan alah panuh, kalam patah dawaik lah kariang, karateh baguluang hanyo lai.

Salam nan kadisampaikan kabakeh Sutan, bak handai kato bidaran, mujua nan sapanjang hari, malang nan sakijok mato. Lah dahulu baliau pulang karahmatullah, jikok utang dikito nan tingga, iyolah manolong jo kami nan sakulimpah, jo doa nan sapatah, limbak sabalik dari itu, kok ado utang jo piutang, utang nan duo perkaro, partamo hutang lahia iyolah /66/ nan barupo ameh perak, bareh jo padi, kain jo baju, jikok adolah baliau nangko manaruh utang nan lahir, mintak disalasaikan dengan warih baliau nan tingga.

Adopun utang nan batin iyolah marupokan muluik nan tadorong, kaki nan talangkah, hati nan takutiro. Tumbuah sarupo iko, nak jan mambarek ateh dunia, nak jan manyeso di akhiraik, dibari baliau nangko maaf banyak-banyak, dari awa sampai ka akhir, kini dunia isuk akhiraik, kito nan jangan batangguhan. Limbak sabalik dari itu, supayo kasiah nak lalu masuak kubua, sayang nak sampaika akhiraik, nak dibacokan kami nan sapatah, doa nan sakulipah, sakian salam dipulangkan.

/67/Pidato Minta Maaf Karano Janang akan ka Tangah Kapalo pasambahan Sakadarnyo

Tantangan sambah jo titah, randah nan dianjuang tinggi, ketek nan diambo gadang, tantang taratuk jo mujilih, kalilo jo sopan, maaf dimintak jo bana Sutan dijalang. Bana nan kapanjalang Sutan, manuruik pitua urang tuo-tuo, adaik di 
lawik bajuru mudi, adaik disabuang bajuaro, tumbuah dialek bajuru janang, dikaji nan kalauik bajuru mudi, tahu diombak nan basabuang, tahu di taluak nan baliku, tahu dikarang mambulintang, tahu ditopan nan katibo, tahu dibadai nan kadatang, mancakau pasang turun naiak.

Jiko dikaji sabuang nan bajuru, tahu disisiak tuah ayam. Tahu d-w-1-g nan bakicuah, tahu ditaruah nan batampek. Jikok disabuik dirajo janang, tahu diadaik rajo-rajo, tahu disakah dengan kain, tahu dihereang dengan gendeang, manjago labiah dengan kurang, tumbuah sarupo iko kini. Karano janang lah ka tangah, kok kurang taratik jo mujilih, lelo jo sopan, artinyo bana kok salah latak bak pakalang, kok salah banang bak kain, nan patuik di ateh kok ka bawah, nan patuik/68/ di ujuang kok ka pangka, baiak disusun cawan jo pinggan, kok ado manaruah kilaf jokilafat, nak dibari suko jo rila, sarato maaf baiak-baiak, sakian salam dipulangkan, diharap buni nak kambali.

\section{/69/ Pidato Mintak Bajalan Baiyo}

1. Sabanyak buah kabanaran Sutan, nan kajadi sahuik jo saponyo. Di ateh gadang nan babangko tanah, basa nan balangkuang aua. Duduak nan sahamparan, tagak nan sapamatang, di ateh kurandam adaik, umpamo bijo dengan bumi, bijo ditanam naknyo tumbuah, patuik disiang kito sisiak, limbak ${ }^{47}$ sabalik dari itu. Aia di langik kito tampuang, ka lantai ubek jo panawa, kok sampai bijo jadi buah, masak nak samo kito makan.

2. Sabanyak kabanaran Sutan, nan kajadi sahuik jo saponyo. Satitiak tidaknyo hilang, sabarih bapantang lupo. Adaik kayo sarakahnyo lalim, dipakai di Pulau Paco. Daratan bagunuang tinggi, lauik basa ba pulau banyak, ba pulau pun banyak bapahuni, tak hilang harok-harok di lauik, kok jauah handak dijalang, hampia handak dituruik. Dicari taluak nan baliku, ka tapek rundiang basawuah, baru parahu dilajukan, kok hujan buliah bapayuang, kok paneh buliah balinduang. Sungguah parahu dilayarkan, rundiang nan tidak bakamudi, sawang tak ado bagantuangan. Lauik nan dalam kaditampuah, ombak c-b-w-h riaknyo gadang, maklum lah Sutan tantang itu.

3. Sabanyak kabanaran Sutan, nan kajadi sahuik jo saponyo, rundiang nan nan tarus ka lautan, banang sahalai indak putuih, /70/ sinan mangikek mako tarang, limbak sabalik dari itu. Sabalik daripado itu, dukun lah langkok jo ramuan,sakik lai buliah mintak ubek, damam lai buliah mintak tawa, tali lah buliahkabagantuang, bumi lai buliah kabapijak, jan lamo sakik ditangguang karano kileklah tapijam, camin tingga dihambo, padoman tingga di Sutan, kilek jo bayang kitopakai, diharap buni nak kambali.

4. Sabanyak buah kabanaran Sutan, nan kajadi sahuik jo saponyo, sambah tajelo dinan rapek, titah tabujua dinan rami, inyo dimukasuik manitahan.

${ }^{47}$ Maknanya: - Limpah; luapl. 
salam tak sampai pado hambo, tapi samantang pun baitu. Manuruik papatah dinan tuo, aia gadang batu babalah, laweh padang barajo anji. Ibaraik kayu tangahpadang, kok urek jelo-bajelo, dahan nan rampak kiri kanan, datang paneh tampaekbalinduang, datang hujan tampek bataduah. Manuruik indang nan biaso, manuruik adaik nan dipakai, diasok baiyo, saso batido-tido, dek alam laweh bakeh tagak, dek bumi lapang bakeh diam, biaso duduak surang basampik-sampik, duduakbasamo balapang-lapang, lalunyo duduak surang basampik-sampik. Angin lalu paham tatambek, kiro-kiro manjaraing angin, taraso lai dapek tidak. Lalunyoduduak basamo balapang-lapang, kurang antah lai kabatukuak ${ }^{48}$, senteang antah lai kababilai, nan tumbuah sarupo iko kini. /71/ Rundiang diambiak jo ukuran,kato dirunciang jo mupakaik. Samantaro kami baiak rundiang jo Sutan didatangkan, lai koh adaik pusakonyo.

5. Sabanyak kabanaran Sutan, nan kajadi sahuik jo saponyo, pihak dihari nan sahariko, bak handai kato bidaran, cupak jo gantang batarajo, batu pusako kito juo, halur nan tidak amuah putuih, warih nan tidak amuh hilang. Dilangkuang adaik jo limbago, dibarih cupak jo gantang, dek luruih tujuan adaik, dek bana jalan baturuik, tapakai juo sampai kini. Diuleh suri ${ }^{49}$ nan tagantuang, diisi gantang nan tatagak, dikaji buah nan dahulu, disabuik kato jan batimbang. Dalam tarajo bayang adaik, kajadi tuah pandapatan, di ateh adaik nan batalago buek, cupak nan tarang samato. Satinggi-tinggi malantiang, lah tibo di awang- awang, suaro tibo ka tanah juo, sahabih n-g-k-h jo rantiang, dikuyak kulik cubadak, tarih pangubak nak basuo, maklum pulang bakeh Sutan.

6. Sabanyak buah kabanaran Sutan, nan kajadi sahuik jo saponyo, nan takilek umpamo camin, nan tabayang dalam padoman. Bakandak adaik jo pusako, nan tasuruak di ujuang lidah, nan takarang di ujuang muluik, dek nan tumbuah iko kini, /72/ limbak sabalik dari itu, nan bak patah kato adaik, bak patitih cupak gantang, jiko tuah dinan sakato, asa rundiang disapakati, dilahia lah samo satu, dibatin samo dilihati. Tumbuah salisiah dek batupang, itulah aka nan cilako, tak buliah kito batupang, itulah akan nan cilako, tak buliah kito pakaikan. Eloklah diam dinan lapang, sampik nan galab mambinaso, sasa jan tumbuah kamudian, nak jan basauk nan baitu, maklum pulang bakeh Sutan.

7. Sabanyak kabanaran Sutan, nan kajadi sahuik jo saponyo, takah dek iyo rahib dunia, budi manangko kailimu, paham babisiak jo nan batin, rumikbatenggang samo surang, nyato senjang bacamin karah, tarang pusako baungkiran, usah maluhak mausaki. Elok di dalam janji mulia, dilangkuang budi nan bakarang.Limbak nan daripado itu, halua dilipek dalam barih, adaik disimpan jo limbago, ukua jo jangko nak sasuai, barih balabeh nak digantang. Tipak ${ }^{50}$ jo patuik nak jan tingga, lelo ${ }^{51}$ jo langgam nak tabaok, maklum pulang bakeh Sutan.

\footnotetext{
${ }^{48}$ Maknanya: -Tambahll. (Moussay, 1995: 721)

${ }^{49}$ Maknanya: - Sisir pada perkakas tenunll. (Moussay, 1995: 1105)

${ }^{50}$ Maknanya: - Tentang, lorong, mengenail. (Moussay, 1995: 1186)

${ }^{51}$ Maknanya: - Tingkah lakull. (Moussay, 1995: 711)
} 
8. Sapanjang parundiangan Sutan, nan talimpah pado kami. Tinggi tagunuang nan bak awan, elok kacang gamangnyo, sadang datanyo balantai papan, halusnyo bak dindiang camin, kok kateh tahimbun jati, ka bawah tabatu intan. /73/ Manih bak santan jo tangguli, lamak bak raso pisang masak, tarang bak lampu tagantuang, janiah bak paneh sudah hujan. Tapi samantang pun baitu, tumbuah sarupo iko kini, dipatuik tak mungkin jadi, bana bapantang kalintasan. Manuruik adaik nan bapakai, tapuak alang babaleh, tapuak siriah bajawek, limbago duduak dinan rami, kok kaciak lai bapangasuh, kok gadang lai bapanginang, rundiang diambik jo ukuran, kato dirunciang jo mupakaik, samantaro kami baiyo, rundiang jo Sutan dilayangkan, laikoh adaik limbagonyo, diharap buni nak kambali.

/74/ Mangambalikan Kato Sasudah Bajalan

Baiyo Pidato Makan atau Minum

Adopun tulak kato Sutan, takah dek kato baitu, agak tahinggo jo talambek, maaf dimintak bakeh Angku. Sapanjang parundiangan Sutan, nan talimpah kapado kami, kok tinggi lah babalik-balik, panjang lah bajelo-jelo, kalo di $<. .>$ tinggi- tinggi, busuak pucuak salarunyo, kalo dikali dalam-dalam, babasuak urek jo isinyo. Ibaraik kasiak di pantai, umpamo bintang di langik, sulik jo sukar mambilangnyo, namun baitu nyo lai kini, kok jajak indak kaditikam, kok kilek indak kadiulang, ditikam jajak koknyo sipi, diulang kilek koknyo cupua ${ }^{52}$, nak janbasuok nan bak kini, ujuang pangasin kami tarik.

Nan pahabisan rundiang Sutan, sapanjang rundiang Sutan tadi, nan kajadi sahuik jo saponyo, manuruik handai jo bidaran, kok Sutan ibaraik langik, kami ibarat bumi. Mano nak titiak dari langik, sipatan bumi manarimonyo, tapi samantang pun baitu, manuruik papatah jo patitah, irik biaso batali, jinjiang biaso batangkai, di hululah sutan mangamudi, kami mandayuang di balakang.

\section{/75/ Bajalan Baiyo Bakato Bamuloh}

Lah sampai disutan, ma Sutan. Tantangan sambah jo titah, gadang nan dilambuk, tinggi nan dianjuang, dinan tadi kito sapadangaan, jo bana Sutan dijalang. Aratinyo nan kajadi kabanaran pulo disutan, taulak kadiri hambo, manurut adaik nan bapakai, dipusako nan barangkuah, kandak biaso batingkah, ditampuang bana nan tabalun, bak dikanduang nan kamaningkah, ditalempong nan kamanalun, kaambiak duduak baiyo, kabaranjuang kato jo mufakaik, iyo baitubana Sutan.

Jawab: sabanyak kabanaran Sutan tadi, ukua jo jangko lah sasuai, barih balabeh lah takanak, kok cupak utang maisi, limbago utang manuang, kok adaik utang mamakai, bak papatah kato adaik, maulua di ateh kayu, mahukun di ateh kato, manyiang tapek nan tumbuah, nan tumbuah sarupo iko kini. kadiambiak ukua jo jangko, isinyo barih jo balabeh, sipaik mananti malah hambo, kabakeh Sutan sapatah, tantangan sambah jo titah, karano alah kato mufakaik, dinan cako kito sadangan, jo bana /76/ Sutan dijalang.

${ }^{52}$ Maknanya: “Dekat ke tepi”. (Moussay, 1995: 277) 
Aratinyo nan kajadi bana pulo dihambo, taulak kadiri Sutan. Karano lah manitah silang nan bapangka, karajo nan bapokok, tuah titah baliau nantun, lah tabik sajo bak padi, lah tumbuah sajo bak bijo, buni lah samo kito danga, rupo lah sudah kalihatan. Manuruik adaik nan bapakai, dipusako bana barangkuhi, kandak biaso batingkah, talampuang biaso batalun, bak nan iko kini, dikanduang nan kamaningkah, ditalampuang nan kamanalun, pandang jauh nak balayangkan, pandang hampia(ng) nak batungkek disutan.

Jawab: sapanjang kabanaran Sutan cako, kurang tak ado kapanukuak, senteng tak tampak kapambilai, tapi samantang pun baitu, diselo dalam daerah, takilek dalam padoman, jo limbago dalam pusako. Alua dilipek dalam barih, adaikdisimpan jo limbago, riak lah tajun jo gambang, nan mudo sipaik mamakai InsyaAllah hambo lakukan.

Jawab: dikabanaran Sutan cako, tarih labiah bak diundang, janiah labiah bak dibasuah, tarang bak bulan ampek baleh bak j-w-k-w dihambo, barek alah dipikua, ringan alah dijinjiang, $/ 77 /$ kok tali alah dirantangkan, kok jalo alahdiserakan, aratinyo bana pandang alah talayang, pandang hampia(ng) alah tatukik dalam itu dapek bulek, nan sagiliang fiqih nan salicik, disuruikkan siriah kagangkuangan, dipulangkan pinang ka tampuaknyo. Aluran gayuang manyambuik, kato manjawek, nak disutan tariknyo.

Jawab: sabanyak bana Sutan tadi, di dalam barih jo balabeh, dilangkuang adaik jo pusako, tapi samantang pun baitu, antaro kito jo Sutan ibaraik urang badunsanak, di mudiak nan sabulakan, di hilia nan samuaro, kok tuah samo dicari, kok malu samo dituntuik, bak nan wakatu kini, aluran gayuang manyambuik, kato manjawek rancak disutan tarabaknyo, hambo ereangkan di balakang.

Jawab: kabanaran Sutan tadi alah taracak jo limbago, alah tasangkuikdalam indang, tapi samantang pun baitu, tabumbun nan tampak jauah, hampia jolong tasunguah. Sapanjang pintak jo pinto hambo, aluran gayuang kamanyambuik, elok di sutan tarabaknyo, rancaknyo tak tasambik pulo.

Jawab: antaro kito jo Sutan, tumbuah sarupo iko kini, /78/ surang balun baragiah, sarikat balun babalah, barek samo dipikua, ringan samo dijinjiang, namun baitu nyo lai kini, tantangan gayuang manyambuik, elok di Sutan tariaknyo, jo mufakaik hambo samoi.

Jawab: antaro kito jo Sutan, rundiangan sajak mulo cako, kato sabanta iko kini, lah pueh batimbang buah, piyuah pilin basarang arek, sariang gantiang tak namuah putuih, jan lamo biduak basauh, pintak jo pinto dilakukan. Sutan jomambaok lalu, hambo manolong di balakang.

Jawab: antaro kito baduo, bak umpamo urang batanun, bak mananai banang lapuk, bak batanun suto basah, dicukia kok indak amuah, diruntiang kok tak salasai, nak jan lamo batang tasanda, kok payah tunggua manangguangkan, maklum pulang bakeh Sutan.

/79/ Pidato Manjapuik Marapulai Khusus

Sasudah kapalo pasambahan

Salamo mahadok bakeh Sutan, sambah nan datang ditarimo, salam nan lalu hambo mulansai. Disusun jari nan sapuluah, tahunjam lutuik nan duo, batakua 
kapalo nan satu, basusun kandak jo iradaik, bahimpun ujuik jo mukasuik. Sambah tahanjok pado Allah, salam tatumpah kapang[h]ulu, nazar tatabua kanan rapek. Himbauan datang bakeh Sutan, tipak di badan diri hambo, lah bulek mako diguliangkan, lah pipih mangko dilayangkan. Kato mufakaik hambo baok, sarato Niniak jo Mamak, bapasan ibu jo bapo, buah mukasuik cinto hati.

Isi mapaham kandak bana, mulo malangkah baranjuang, naiak ka tanggo rumah iko, kok tagak alah tajalai, kok duduak alah taselo, niaik mukasuik dari rumah. Dipakaikan adaik nan tigo perkaro, partamo siriah jo pinang, banamo basojo basi. Kaduo garak jo garik, pamenan tangan dinan rami. Katigo sambah manyambah, sopan jo santun dalam adaik.

Nan kajadi sambah jo titah, nan niaik di dalam hati, agar di ujuang lidah, kok janji hambo tapati, agar hambo muliakan, amanah dipacik salamonyo, tumbuah sarupo iko kini. Batang batitih hambo kabuang, aia taganang hambo sauk, rantiang disakah hambo ganggam, baniaik patang jo pagi, /80/ bacinto siang jo malam, pintak jo pinto hambo lakukan.

Pihak ka badan diri Sutan, tuo jo mudo tak dihituang, hino jo mulia tak disisiah, nan sakarang iko kini, kami manjapuik marapulai. Panggatok naknyo mairiang, anak mudo sarantak turun, sangajo japuik nak babao, Sutan mahanta naknyo sampai. Nan mano sagalo alek jamu, turun di tanggo rumah nangko, naiak ka janjang kampuang kami, pintak jo pinto nak babari, lahia jo batin nak sasuai, sakian bana dipulangkan, nak dalam timbangan Sutan, diharap buni nak kambali.

\section{/81/ Pidato Manyusun Kadudukan}

Sungguah pun Angku surang nan dituntuik, saruan kami nan basamo. Samego tumpuan puntiang, sariaik adaik nan bapakai, naza kapado isi rumah. Niniak Mamak junjungan salam, karik baiak samo dicinto, sinan lah salam ditibokan. Salam nan kaditibokan, kalo manyiang dinan tumbuah, manambang tampek nan ado, nan tumbuah sarupo iko kini. Tasabuik adaik nan kawi, pakaian sarak nan lazim, siang malam dalam anjuran, patang pagi samo dicinto.

Dunia sah, langgam badiri, habih tahun baganti musin, adaik bapakai salamonyo. Alah asa siang bak hari, alah nyato tarang bak bulan, limbago sabuang bajuaro, galanggang bahampang limo, alek jamu basapangkaan, nan jadi jamu si pangkalan, nyatolah Angku jo Pang[h]ulu, karik baiak ipa bisan, sarato dunsanak jo sudaro. Kok bisuak salah satunyo, dek banyak ragu mandatang, dek lamo lupo kok tibo, sababnyo mako dimungkin, karano alek lah tibo, limbago jamu lah datang, alek jamu sapanuh rumah, saruan sakorong kampuang.

Lah panuah rangko hati Mamak, santoso hati ibu bapo, manyanang dalam pikiran, mambayang kahalua patuik, /82/ malihek dunia nan tarantang, tak anggak batapuak tangan, dilingong barih ka ujuang, lah nyato bandua bajuntai, tampaik limbago main handai, ungkiran kunjuang nan ampek, sasak dialua dengan patuik, patuik dirundiang kato bana, bapetak ruang di tangah, bacupak bagantang panuah, cupak adaik labuhan kato, naraconyo lautan budi.

Tapi samantang pun baitu, dalam hiyo rusuah mandatang, sababnyo mako dimungkin, pihak diduduak kito kini, juku takilek jo aronyo, nan tinggi kokkurang anjuang, nan gadang kok kurang amba, sarago sasak jo sampik, barih di 
ujuang kok ka pangka, alua di tangah kok ka tapi. Sakalipun tidak di tampaiknyo, asa dilangkuang barihnyo. Kok tidak aman jo santoso, lagi kok tidak sahantaro, pintak jo pinto nan mandatang, kami mintak maaf lahir batin, sarato suko jo rila, diharap buni nak kambali, nak sanang hati si pangkalan.

\section{/83/ Pidato Mintak Diri Sacaro Pendek}

Kapalo pasambahan caro pendek

Tembak katibo ka alamaik, pandang katibo ka sasaran, dek alua jalan baturuik, dek jalan pasa batampuah, diadaik pusako kito. Tapi samantang pun baitu, di ulu mantari naiak, Timur bandarang hari siang, lautan medan parahu, kato-kato medan pang[h]ulu, siriah jo pinang medan adaik. Diadaik nan jiniah, dicupak nan papek, digantang nan duo baleh, ayam tapahek di juaro, pedang tapahek dipandeka, kain balipek dalam peti, ameh babilang dalam puro.

Pandai mahetong dinan ganjia, tahu mamapa dinan banyak, parahu balaiadi lautan, langkok panjalang jo pangayuah, layar takambang angin tibo, barambuih angin dari barat, batamo timur jo salatan, salamaik parahu ka labuhan. Karano angin lah taduah, limbago ombak lah tanang, riak badabua kiri kanan, kok kabuik alun talayang, kok hujan alun taserak, ikan nak pulang ka lautan. Aia nak hilia ka muaro, aluran rundiang nan tingga, utang nahkodo mahunikan, baliau mintakkarilaan, izin nak buliah dari Angku.

/84/ Mangambalikan Kato Sasudah Bajalan Baiyo

Kapado lawan kito barundiang nan mulo-mulo

1. Sapihak disambah jo titahnyo, taratik jo mujilihnyo, nan tadi nan di anjuang tinggi rimbo gadang, lai nan kini maaf dimintak, jo bana Sutan dijalang. Bana nan kapanjalang Sutan, cukuik dinan tadi ulik sarago basigih, lambek saragi di jalan, pihak duduak nan baiyo, tagak bamuloh, panjang tatulih ateh bahu, babantalatak di kapalo, barek tak dapek manggiliangkan, aluran gayuang manyambuik, kato manjawab, taulak kadiri hambo.

Tapi samantang pun baitu, dek ulah upayo kurang, kuaso jauah sakali, bak handai kato bidaran, eloklah kato paralukan, kurang paham tarabo-rabo, kurang alim suluah kok padam, sababnyo mako baitu, jajak ditikam kok nyo sipi, kilaian diulang koknyo cupua. Tapi samantang pun baitu, nan talatak dalam panitahan, nan tasimpan di dalam alua, lah ditilik jo budi halus, lah ditimbang dalam kiro- kiro, kok batang patuik dititiah, kok kilin patuik diulang.

Disabuik kok batimbang buah, juluk jo ragi kok dihituang, bak ombak lauik sailan, bakumpua karang ka tapi, baralun galombang di lautan, galab kutiko bumi nangko, namun baitu nyo lai kini walau bak mano ragam kato, walau bak mano ragam rundiang, namun $/ \mathbf{8 5}$ / gayuang wajib disambuik, bana kato paralu dijawab, nan kajadi bana pulo dihambo, nan jinak sajo hambo cakau, nan lia nak tabang jauah, laikoh adaik limbagonyo, maklum pulang bakeh Sutan.

2. Sambah tajelo dinan rapek, titah tabao jo dinan rami, iyo dimukasuik pasambahan. Salam tasampai pado hambo, biduak tatumbuah lah basauah, kato 
tak dapek lah bapikir, pikir itu palito hati, haniang hulu bicaro, tanang subayo aka, dalam saba bana mandatang. Panek manjadi parantian, paniang manjadi pamalaman, sawajah duduak baitu, tagak bamulah. Jugo dihambo duduak lahbamulah, tagak lah baiyo, dalam nantuan pedang tasanda ateh bahu, baban talampok di kapalo, barek tak dapek manggilingkan, aluran gayuang manyambuik kato bajawab, tatumpah kadiri hambo, karano gayuang kabasambuik, kato kadijawek, kok dikanduang mujua jo malang.

3. Sabanyak buah kabanaran Sutan, nan kajadi sahuik jo saponyo, jugo tadi kito baranti kito sakutiko, manjadi bulek nan sakaliliang, isinyo pipih nan salicik, dalam nantun lah dapek rundiang nan saiyo, kato nan sapakaik, tatumpah kadiri hambo, sawajah gayuang manyambuik, kato manjawek, namun baitu nyolai kini, tagah dek adaik jo pusako. /86/ Dibarih cupak jo gantang, bak handai katobidaran, satali banang jo suto, bapiyuah mako bapilin, sasuai mako dikamba, talutan suto disuri, tarantang tanun dipenteh, barantak baukir ragi, dipinta sado nan lapuak, turak nak samo lalu juo, bangkalai nak lakeh jadi baju, maklumpulang bakeh Sutan.

4. Sabanyak kabanaran Sutan, tinggi tagunuang nan bak awan, elok kacik gamangnyo sadang, datanyo balantai papan, halusnyo bak dindiang camin, kok kateh tahambun jati, ka bawah tabatu intan, manih bak santan jo tangguli, lamak bak raso pisang masak, janiah bak paneh sudah hujan. Tapi samantang pun baitu, kalo sahukun di ateh kato, maukua di ateh kayu, manyiang tampek nan tumbuah, tumbuah sarupo iko kini, dek patuik tak mungkin jadi, bana bak pantang kalintasan, nan kato iyo baitu, dituruik barisan adaik. ditampuah aluran cupak, diangkek sambah jo salam, hulu malang salah galogok, hulu baiak handai batenggang. Marintang kok salah kakok, suto jo banang ko batimbang, buruak buni pacah barito, kurang elok didanganyo, nak jan tasui nan baitu, maklumpulang bakeh Sutan.

\section{/87/ Pidato Mulo-Mulo Akan Mambukak Parundingan}

1. Salam nan akan dipulangkan, nan jauah makanan turuik, dek hampia tampek bajalang, salam jo maaf pamanuahi. Tanamo ayam nan barinduak-rinduak, limbago karokok nan bajunjuang, dek diagaknan batapatan, tatamu kalah nan basandaran, nan tinggi nan tampak jauah, nan dakek jolong basuo, nan mamacik gantiang putuih, nan mamegang bayang tabuak. Limbago adaik nan kawi, nan lazim di dalam sarak, kato sapatah hambo sabuik, rundiang sabuah tando izin. Aia nan janiah di muaro, bana nan ado dari Angku, ampun kan kato jo mufakaik, kok buliah pintak jo pinto, di ateh duduak nan sahamparan, bana mamegang karapatan, hambo minta izin jo rila, buah mukasuik cinto hati, nyato tasimpan dalam batin, alah koh buliah dilaiakan, nak sapinto dari Angku.

2. Aluran nan tidak amuah putuih, warih nan tidak namuah hilang, tapakai juo sampai kini. Dek lurus tujuan adaik, dek bana jalan baturuik, ulasan suri nan 
tagantang, isinyo gantang nan tatagak, dalam naraco bayang adaik. Adaik nan batalago buek, cupak nan tarang samato, maklum pulang bakeh Angku. /88/Aratinyo bana niaik di hati nak dibukak, naza dikanduang nak tahurai, nak tasipaik batin kanan lahia, alah koh tibo di barihnyo, nak patawa dari Angku.

3. Dihaluran adaik nan bapakai, pusako nan barangkuhi, ruponyo adaik lah samo kito pakai, pusako lah samo kito rangkuah. Adaik nan samo kito pakai, kok jauah jalang manjalang, kok hampia turuik manuruik, sakarang lah taselo di rumah sabuah nangko, kok diagak di dalam hati, ditimbang dikiro-kiro, dalam mupahum

\{pamahaman\} hati kami, lah sasuai mungkin jo patuik, lah satimbang luruih jo bana, lah samo ukua jo jangkonyo, alah koh patuik kami bapanyabuik, nak panyatu dari Angku.

\section{/ 89/ Tadorong Mintak Disentak}

1. Karano hambo barek nan kamamikua, ringan nan kamajinjiang. Isinyo gayuang manyambuik, kato manjawek, dek harek dinan kabuliah, dek camehdinan karugi. Bak umpamo urang mamanjek, dek harok buah nak dapek, kok tanggung jambau ka dahan, ka bumi kaki kok sayuik, tagamang tumbuh maso itu, kabek ko lah kalataknyo, nak pitua dari Angku.

2. Karano kaki kadilangkahan, tangan kadijambauan, kok basauk mujua nan taraiah, tatampang di parahu hilia, angin lunak kalimbang tanang, taranglautan bacuaco. Bak pasang masuak muaro, bak awan ditido badai, salamaikparahu ka labuhan, bak kok tumbuah malang nan taraiah, tatampang di parahu mudiak. Angin kareh galombang gadang, batiup cando badai garang, bapusiang cando halimbubu, pulau tak tantu kadituruik, takarang parahu di lautan. Bak bakoh adaik limbagonyo nak panyatu dari Angku, isinyo hanyuik nak bapinteh, tabanam nak basilam, takarang nak bajapuik diangku.

3. Kok tumbuah mujua nan taraiah, bak umpamo urang balaia, angin elok layar salasai, taluak tak ado nan baliku, karang tak ado mambulantang, jalan taruih parahu laju, bagai bak pucuak /90/ dilancakan, salamaik parahu pulang pai, santoso masuak kalabuhan. Kok tumbuah malang nan taraiah, umpamo parahu dalam lauik, angin dareh galombang gadang, riak manantang kiri kanan, dipandang gunuang lah batungkuik, dicaliak lauik bakamarau, biduak tirih padoman hilang, jalan nak tantu kadituruik, itunyo lai kadipulangkan.

4. Kok basauak mujua nan taraiah, bak biduak dikayuah hilia, bak pasang masuak muaro, janiahyo labiah bak dibasuah, tarang bak bulan ampek baleh, elok bak paneh sudah hujan. Kok bisuk malang nan taraih, tikam sayup gayung tak sampai, jariang bapilin tak barisi kacang malilik mati pucek, ikan babubun jalo putuih, kok tak talenong bak batanun, kok tak tasangkuik bak manjalo, itu buni nan kadipulangkan bakeh Angku. 
5. Kok tumbuah mujua dinan taraiah, bak dadak ${ }^{53}$ dalam kisaian, bak kabuik diambuih angin,bak awan manjajah gunuang, bak kok tumbuah malang nan taraiah, kok kampuang jorok manjorok, taluak liku baliku, lurah nan dalam taturuni, rantau nan jauh nan baturuik, karano hari malam tabing babelok, lahir jo batin mintak tolong, maklum pulang bakeh Sutan

\section{/91/ Alua Bayang Tinggi}

1. Salam nan kadipulangkan bakeh Sutan, dihambo adaik jo Tungganai ${ }^{54}$. Sambah talangkuang tantang alua, salam tibo patuik lah dati $\{a\} n$ g, lembak sabalik dari itu. Ujuik satu pangana bunta, naza mukasuik dalam hati. Papatah adaik jo limbago, kini bak handai jo bidaran. Ibaraik panjalang jo parahu, nan kato angin lah turun karano laia lah takambang, niaik naza ka palabuhan, nak lakeh tibo di pulau tagaklah sutan di kamudi, nak hambo batenggang dahuluan.

2. Dikabanaran Sutan nantun, nan kajadi sahuik saponyo, sambah tatenggang balimbago. Lah nyato katampuak adaik, tantu kahambo mukasuiknyo, tumbuah limbago dalam alua, ditilik handai jo kiasan, hambo mambana tantang itu. Tumbuah sarupo iko kini, mungkin jo patuik nak jan tingga, lelo jo langgam nak tabao (tabao), sidik jo bana nak tapakai. Kini bak handai jo bidaran, bak umpamo urang manyuruak, nan kato ru[m]pang lah panuh, mato jo turang samparono, nak sanang tingau (tingau) bajalan, karano ikan lah takilek, eloklah jalo diserakan nak sanang hati guradji?.

3. Tapi samantang pun baitu, adaik tarang pusako nyato, cupak /92/ jo gantang nak barisi, indanglah panuah jo limbago. Dek nak tumbuh iko kini, lukih agakan lah dijangko, urang maukur dibalabeh, dapek dihambo kiasannyo, limbak sabalik dari itu. Jatuah tagamang k-j-w-a, hibo jo rusuh kan bapucuk, hambo nan punjungan adaik, kini bak handai jo bidaran, bak umpamo urang balaia, pulau tampak panjalang nyato, mukasuik sutan manguliliang, nak lakeh naik ka labuhan,pulang maklum bakeh Sutan.

4. Tapi samantang pun baitu, niaik jo naza dalam hati, aluran adaik di Tungganai. Basambia jo baso basi, nak dapek dirangkuah kato, dek nan tumbuah iko kini. Bak handai papatah urang, nyato janjang dilandasan, nyato barih dibalabeh, nyato tantu manangguang kalandasan. Karano ikan lah takilek, lah nyato jalo baserak, mukasuik hambo ka Sutan, nak sutan marapek rantai.

5. Tapi samantang pun baitu, sambah tatunggang lah manyampai, sungguah tabayang tampak jauah, tatu b-y-r dipandang rupo, padoman taruihdinan tarang, nyato ka hanyo mukasuiknyo, nan niaik dek Sutan, adaiknyo tembak

\footnotetext{
${ }^{53}$ Maknanya: - Serbuk halus dari kulit padill. (Moussay, 1995: 282)

${ }^{54}$ Maknanya: - Kepala rumah tangga, yakni seorang laki-laki tertua dari keluarga yang mendiami rumahgadang menurut system keibuan di Minangkabau. Ia berkuasa keluar, sedangkan ke dalam adalah saudaraperempuannyall. (Saydam, 2004)
} 
baalamaik, buruang di langik tujuannyo, kan baniaik papatah adaik, tapi samantang pun baitu. Kaciak bacacah nak tabao, gadang babingkah nak tapakai, leba bakapiang pado adaik, limbak sabalik dari itu. Bak handai kato bidaran, bak umpamo bungo /93/ kambang, coyong ko rupo bamukasuik, nyato kabuah alamaiknyo, mukasuik daun jo batang, samantaro buah lai masak, jan gugur ditimpo paneh, tantu batenggang pado adaik, maklum pulang bakeh Sutan.

6. Nan kajadi sahuik jo saponyo, taguah siasaik nyo samparono, $<$. > baalamaik, tantu kahambo taradoknyo, tumbuh sarupo iko kini, antaro kito jo Sutan, jauh nan tidak baantaro, hampia(ng) nan tidak basuatu, antaro tidak tarupo, suatu tidak kalihatan. Tapi samantang pun baitu, bak kato indang jo bidaran, bak umpamo urang batanun, suri tarantang karuah tibo, turak jo paso ${ }^{55}$ lah sajalan, suto lah masuak ka sikoci ${ }^{56}$, banang bapinta likutan, kini lah sampai jadi kain. Mukasuik di hati nak mangguntiang, bangkalai nak lakeh jadi baju, pulang maklum bakeh sutan.

7. Tapi samantang pun baitu, nak nyato buntanyo adaik, tantu dilipek jo limbago, kini lah sampai kaukuran, adaiknyo kato kan bajawek nak dipangka tumbuah baniah (baniah) kababaliak, nak di bumi tumbuh bijo, nyato diawa mulo jalan, tantu diawa akhir kato. Limbah sabalik dari itu, nan jadi niaik jo mukasuik, maadok kabadan diri Sutan, angkatan sambah dipatinggi. /94/ Salam jo maaf basarato, buni nak samo kadangaran, pado waktu iko kini, jatuah papatah jopaparan, bak kato indang jo bida, karuk sugiro agiah banang, nak nyato suri ditanun, nak tarang kanji diuleh, tantu salasai jalan turak, sinan banamo kain sudah, maklum pulang bakeh Sutan.

8. Tapi samantang pun baitu, panilaian timbangan hambo, cupak usali kan lah panuah, gantang panyawuaklah barisi, tantu diangkek sambah salam, alah salamaik ditarimu, lembak sabalik dari itu. Bak handai kato bidaran, bak umpamo urang balayang-layang, nan kato angin lah tibo, tantu manolong angkek kabuik, lahirnyo batin dapek tarang, awa jo akhir tampak nyato. Kok kusuik banangdipuntaran, putuih nan tidak bakarano, kabek sabalik buhua sentak, uleh salingkajan mangasan, buhua sabuah jan mambuko, pulang maklum bakeh Sutan.

9. Tapi samantang pun baitu, salam nan baru diangkek, sambah nan jolong dipamulai, disangkuikkan paruah kanan tinggi, dihampakan sayok kanan gadang, nak dapek tando nan sapaguh?, nyato kasutan alamaiknyo. Limbak sabalik dari itu, bak handai kato bidaran, angin bapesong m-k-n di rimbo, ribuik bakampakan di lurah, tantu /95/ nan tinggi mukasuiknyo, jatuah ka bawah jadi tolong, karano kilek alah tapijam, camin tingga dihambo, padoman tingga disutan kilek jo bayang kito pakai.

\footnotetext{
${ }^{55}$ Maknanya: "Penggulung kain dalam gedokan". (Moussay, 1995: 881)

${ }^{56}$ Maknanya: "Tempat gelendong benang di bawah jarum”. (Moussay, 1995: 1063)
} 
10. Tapi samantang pun baitu, antaro kito jo Sutan jauah tak tarang antaronyo, hampia tak nyato basuatu. Leba dikambangkan bapakai, laweh barubik kan biaso, panjang lah tantu bakaratan, tumbuah sarupo iko kini, niaik naza mukasuik hambo. Sutan mangambang lipek lahia, nak nyato tarang dahuluan, nak elok jalannyo alua patuik, limbago sabalik dari itu. Tarang limbago kito buek, tantu sakato manyudahkan. Kini bak buni kato papatah, sato alur jo kiasan, adaik, adaik puku \{puru $^{57}$ di tangah lauik, ombak galombang ditangguangnyo, topan jo badai ditahannyo, nak hilang nan sado itu tantu ditahan dialau angin, maklum pulang bakeh Sutan.

11. Tapi samantang pun baitu, adaik bapakai kan lah nyato, cupak usali kan lah tarang, lah tantu ka tujuannyo. Alua jo patuik lah dituruik, nyato kahambo mukasuiknyo. Manuruik papatah jo paparan, kiasan manantang patuik, dapek dihambo tando panuah, limbak sabalik dari itu. Bak handai indang jo bidaran, bumi laweh langik leba, lauik sati rantau batuah, /96/ urang balaia bapadoman, pabilang badayuang dikamudi, nak hilang maro di lauik, kini lah tampak rupo pulau, jangan disangko palayaran, babiduak nak samo jo sakoci, maklum pulang bakeh Sutan.

12. Tapi samantang pun baitu, adaik mamakai kan lah nyato, sarak mangato kan lah tarang. Bak indang kato pusako, limbago batampaik diam, adaik nan buntakan lah takambang, di sinan buek jadinyo, tumbuah sarupo iko kini. Bak papatah kato adaik, umpamo kasiak bajalan, rangkuahan manyuruah pai, tantu dinan data barantainyo, pulang maklum bakeh Sutan.

13. Tapi samantang pun baitu, adaik pusako undang-undang, cupak usali paka[i]yannyo, adaik limbago tampaik diam, ungkiran silang jo salisiah. Anak kunci peti bunian, urek tunggang lah nyato dalam, pucuak bulek lah nyato tinggi, limbak sabalik dari itu. Adaiknyo tembak baalamaik, buruang di langik tujuannyo, tuhua dibadia bajugalo ikan di lauik dijariangnyo. Cukuik ditiliak jo timbangan, hati dikirokiro, duduak adaik lah saedaran, nyato pusako sabandiangan. Manuruikpapatah jo patitah, angin turun lah nyato tarang, lihek dek Sutan tiang layar, tantu manjadi tukang dendang, nak nyato Pulau Langkupuri, pulang maklum bakeh Sutan.

/97/ 14. Tapi samantang pun baitu, nak tarang cupak usali, nak nyato kato pusako, sarak lazim adaiknyo kawi. Kato bagian di ateh tumbuah, salam suji pusako nyato.Ameh babingka lah tabayang, nan bapakai di dalam itu, nyato lakuk kan dek linjau(linjau), nyato tarang kan dek sigi, di sinan dapek tahu baiak. Limbak sabalik dari itu, kini bak handai jonyo $<$.. $>$, bak umpamo urang sakik, sutan mancari ubek tawa,dukun kahambo mukasuiknyo. Cukuik dihambo angin lantiah makrifat lunjung, hakikaik tak kunjuang putuih, makrifat tak namuah tabuak, jan lamo sakik ditangguang, pulang maklum bakeh Sutan.

${ }^{57}$ Kapal (Moussay, 1995: 919) 
15. Tapi samantang pun baitu, manilik buni jo saponyo. Ujuangpangkanyo babalabiah, cupak usali p-m-y-n-y-w, limbak sabalik dari itu. Nan pintak hambo kasutan, pendek bauleh kan bak datang, gadang batampek pado adaik. Bak handai papatah urang, manilik di ateh roman, mamandang di ateh rupo,banilai di ateh mungkin. Baharago di ateh patuik, nan kato kapalah tibo, karano sauahlah turun, Sutan janiah kan tantang itu, nak sanang hati kalabuahan, pulang maklum bakeh Sutan.

16. Tapi samantang pun baitu, talangkuang adaik jo pusako, tantu malimpah kanan rapek, sababnyo mako d-m-k-y-n, jajak batikam kan bapakai, kilek baulang kan biaso, ulaknyo kato /98/ kan nak tarang, nak tantu ujuik jo mufakaik. Lakuk lah nyato dibatinjau, tarang lah nyato dek basigi, lihatan adaik nan basamo, tantu panilik jo timbangan, bueh taguah kapangabek, kato banabapajunjungi asa mulonyo, itu nan rangkuhan adaik. Ibaraik padi di sawah, lah nyato bu\{a\}niah satangkainyo. Limbak sabalik dari itu, bak handai indang jo bidaran, kuriak jo balang lah sarupo, rabah jo tagak lah sasuai, kini batanam jo pagaran, nak didahan tumbuah rantiang, nak ditampuak tumbuah bungo, maklum pulang bakeh Sutan.

17. Tapi samantang pun baitu, adaik lah tarang dalam alua, langkuangan pusako lamo, jalan nan diuleh baturuik, kato nan duo lah bapakai, kato nan ampek di dalamnyo, ruponyo kandak lah nyato buliah, pintak lah nyato balaku, buhul dimulai dipasudahi, kato ikek nak b-r-l-n-s, tantu dipandang nan basamo, elok naktarang dinan banyak. Limbak sabalik dari, nak handai indang jo bidaran, umpamo suntuak 58 jo jalujua, lalunyo sahinggo pahek, nak suruik maluangkan jalan, nan elok dialur patuik, nak sanang tanam-tanaman Sutan siramlah jo aia, maklum pulang bakeh Sutan, diharap buninak kambali.

18. Dikabanaran Sutan nantun, nak kajadi sahuik jo saponyo, /99/ putiah basasah lah tarupo, lah tarang manahan aia, lah nyato tarangkek lunau, hitam batapukan biaso, lah tantu manahan basi, buleknyo aia nyato tungkang,karambuang dilaluinyo. Langkah sahayun lah satapak, dek bulek sakato tibo, lalu salambai lah manjadi, kato lah Sutan banakan. Bak handai papatah urang, coyong di langik kan barupo, nyato kapaneh mukasuiknyo, gabak di hulu ganti tando,tantu kahujan alamaiknyo, nan kato iyo baitu, bijo ditanam nyato tumbuh, Sutan lakukan salah satu.

19. Tapi samantang pun baitu, adaik lah tibo dima kamanyo, dimuhilih kito nan basamo, itu nan kato dahulu, kini lah samo ditapati. Manuruik indang jo papatah. Ingek kato mufakaik, ibaraik biduak jo parahu, umpamo kamudi jo haluan, ragu mananti ombak tanang, bimbang manangko pasang suruik, dirangkuah dayuang basu(i)lambek, niak nak sampai ka kualo, naza nak tibodilabuhan. Tagaklah Sutan di kamudi, hambo batenggang dahuluan, nak sanang hati nahkodo, pulang maklum bakeh Sutan, kambali buni pado kami.

\footnotetext{
${ }^{58}$ Maknanya: "suntuk, sepanjang". (Moussay, 1995: 1103)
} 
20. Tapi samantang pun baitu, mungkia jo patuik nak jan tingga, lelo jo langgam nak tabao, sidik jo bana nak tapakai, lahir jo batin naknyo samo. Paham bulek mukasuik putuih, sabab dek kato dahulu, tarangnyo adaik barangkuhi, /100/ nyato pusako baungkiran. Limbak sabalik dari itu, bak handai kato bidaran, umpamo urang balaia, sungguah dakek ruponyo pulau, lauik jan sangko muaro, kok tumbuah maro malintang, dikarangparahu tangah lauik, ombaknyo cabuhriaknyo gadang, tantu bamusin palayaran, hari pabilo kasampainyo, nak basauk baitu, nak sanang hati p-w-a-w-g, pulang maklum bakeh Sutan.

21. Tapi samantang pun baitu, cupak lah panuah janyo hambo, gantang bapapek lah balilih, dek kato sudah baliga, asa mulonyo dipatarang, sababnyo mako damikian. Nan rundiang Sutan kahambo, katolah nyato bakiasan, dapek dek hambo mukasuiknyo, kini bak mamang Niniak jo Mamak, bak indang kato pusako, karano naraco lah tagantuang, ameh babingka alamaiknyo, tahelo nan ganok mukasuiknyo. Kini nak naiak katimbangan, nak tantu lubang timbagonyo, pulang maklum bakeh Sutan.

22. Tapi samantang pun baitu, urang balaia ka(n) Mamuju, tantu ka pulau mukasuiknyo. Urang babilang dari aso, kini lah dapek parantian, adaik jo indang bakarasai, nyato pusako nan mangato, tarangnyo tahil nan mamakai. Cupak jo gantang lah tajulai, sakian bingkanyo ameh, paham lah tibo pado hambo. Limbak sabalik dari itu, bak papatah kato adaik, layar turun angin baranti, sauah jatuah kapa managun, pabilang lah tibo dilabuhan s-w-anak samo jo sikoci, Sutan tarimo elok sajo, /101/ pulang maklum bakeh Sutan, diharap buni nak kambali.

23. Tapi samantang pun baitu, nan pangana pikiran hambo, niaik sampai naza baranti, mukasuik putuih sandirinyo. Di ateh tuah nan sapakaik, kini nan jadi pintak hambo, salam diangkek kanan rami, titah dijunjuang kanan banyak, sababnyo mako damikian. Duduak lamokan biaso, rusuah dipanek nan kadatang, tagak lamukan biaso, gaduah dipaniang nan katibo. Limbak sabalik dari itu, bak handai mamang rang Minang; barang simpan panjalang sarik, mukasuik piliang nak balaia, niaik jo naza nak manompang. Sutan tarimo elok sajo, pulang maklum bakeh Sutan.

24. Tapi samantang pun baitu, sadang mangato lah manyampai, adaik mamakai lah manyadang, limbago badiri jo niaiknyo. Papatah adaik mangatokan, janjang latiah jangko balabiah, tantu sajarah dahulunyo. Kini lah jadi alua patuik, tarang dek kito kiasannyo. Limbak sabalik dari itu, tantangan kandak Sutan kahambo; bak ibaraik padi di sawah, lah nyato buniah sarumpunnyo, nan masak sabik disutan, nan mudo hambo manuai, nan hampo tingga di jarami, kabusuaknak tabang jauah, Sutan tarimu elok sajo, maklum pulang bakeh Sutan.

/102/ 25. Tapi samantang pun baitu, panilik timbangan hambo, nangkodo marapekkabilang, p-w-a-w-n-g timbo, juru jo r-a-g-k nak balaia, tantu ka pulau mukasuiknyo. Dapek di hambo tando panuah, limbak sabalik dari itu, bak handai 
indang jo bidaran, kini basambia jo kiasan. Dahulu rampak rambun daun, kini lah suruik manyaluru, ambun satilik dari langik bacibo sabuah dari bumi. Mukasuik hambo jadi lauik, pulang maklum bakeh Sutan.

26. Tapi samantang pun baitu, data baranggang kan lah tangga, buliah tapakai lah tabuang, nan jadi sahuik jo saponyo. Rundiang paparan hambo danga, tantu basambia jo kiasan, kini bak handai jo bidaran; mukasuik hambo kan nak kareh, kini pamandak ${ }^{59}$ nan lah tibo. Nak ulam ${ }^{60}$ pucuak manjulai, nak janjian galang lah buliah, tadinyo sumua nan dikali, kini lah nyato aia datang. Sangkuikkan budi ka naraco, gantangkan paham katimbangan, nak nyato nanhalus haniang, nak tarang mungkin jo patuik, hambo mambana tantang itu, pulang maklum bakeh Sutan.

27. Tapi samantang pun baitu, niaik mukasuik dalam hati, nyato kasutan alamaiknyo. Nak tarang pangkanyo kayu, ingek baniro nan bapunta (bapunta), nak dapek diasa jalan, tantu kapangka kasudahahnyo.

/103/ [28]. Tapi samantang pun baitu, umpamo urang basipak rago, tinggi malambuang ka udaro, mukasuik ka awang-awang, jatuah ka tanah kan biaso. Tantu babuek pado adaik, pihak dibadan diri hambo, tinggi tagak kandek sabab, elok bumi bakarano. Bak umpamo saluang jo bunyinyo sajo kadangaran, rupo balun Sutan lihek. Limbak sabalik dari itu, bak kato indang jo bida, tadinyo tingaulah bajalan, tantu kamano mukasuiknyo, kini runang lah baranti, lah dapek tando sudahnyo. Piliah dek Sutan rupo turak, nak salasai jalannyo jalo, maklum pulang bakeh Sutan.

29. Tapi samantang pun baitu, lalunyo adaik jo pusako, manantang lukih kato bana, dahulu sifat limbago, kini lah tumbuah jo kiasan. Ibaraik buruang di udaro, tinggi tabang dek basabab, salasai ikua jo rumbaian, turun ka tanah kan biaso, nyato papatah mangatokan.Limbak sabalik dari itu, bak papatah kato adaik; kok aso lulua malulua, kok duo tahanlah ganok, mahentak rueh ka buku, malakok bungo ka tampuak bajingkang dahan jo rantiang. Nan elok jalannyo alua patuik, maklum pulang bakeh Sutan.

30. Tapi samantang pun baitu, panilik timbangan hambo, p-n-w-w-i kato iko kini. Kok lamo ulai jo ulai, /104/ jabatan rundiang basauran. Buruak buni pacah barito, kurang elok didanga buni, tak baiak dipandang rupo, nak jan bisuak nan bak kini. Kok lai buliah pintak jo pinto, nak dapek kato nan sungguah, elok suruik nak batanam. Diganjua balik jo rundiangan. Bak kato indang jo bida, duo tigo kalimaik datang, mukasuik hambo basulambek, lah nyato pinang sabatang, datangnyo pipik tak tahinggo, pulang maklum bakeh Sutan.

\footnotetext{
${ }^{59}$ Maknanya: - Pendongkok kerisll. (Moussay, 1995: 851)

60 Makanya: -Daun-daunan atau buah-buahan mentah yang dimakan dengan nasi lalapll. (Moussay, 1995:1225)
} 
31. Tapi samantang pun baitu, nak tarang kandangbatingkah, nak nyato takampuang batalun, papatah adaik mangatokan; bak umpamo urang balaia, tantu mahadang palabuhan, nak nyato pulau kadituruik, sutan lah duduak di kamudi, hambo batenggang didahuluan, nak elok rangkuhan dayuang, sabab dek malihek angin kini, diganjua tiang tiang layar. Sauah lah tajun ka lautan, barang nak turun jo sikoci, nak sanang hati nangkodonyo, pulang maklum bakeh Sutan, diharap buni nak kambali.

32. Tapi samantang pun baitu, mamandang di ateh rupo, manilik di ateh roman, basiang di ateh tumbuah, manimbang tampaik nan ado. Papatah adaik mangatokan; langkah sahayun kok batuka, layok salembai kok balain, rabah jo tagak kok batenggang. Batuka colok jo ragi, balain /105/ turak jo kalair, batingkahturak jo pasok. Buruak rupo dipandang urang, tak elok dipandang mato, limbak sabalik dari itu, papatah urang tuo-tuo; kubak pisang siso dimakan, hanyo diisi katabuang, tarik isi dibuang kulik, sayang dikulik nan kapai, kan lah pikirantampuak, maklum pulang bakeh Sutan.

33. Tapi samantang pun baitu, niatan naza jo mukasuik, agaknyo adaik kan lah nyato, bakeh limbago lah batipak pado wakatu iko kini, panilik timbangan hambo, kato batukuk kan lah tarang. Rundiang balabuah lah manjadi, lah nyato ujuik mukasuiknyo, kini nan jadi niaik jo naza, papatah adaik mangatokan; tarang panjalang nan lah tibo, nyato sikoci nan lah datang, niaik mukasuik juru mudi, tantu ka pulau nan sabuah naknyo salamaik palairan, jan dapek maro di lauik, maklum pulang bakeh Sutan.

34. Tapi samantang pun baitu, leba balangkuang dalam adaik, panjang maluak jo limbago, nyato pusako baungkiran. Di sinan tampuaknyo alua, dapek dek kito kiasannyo. Limbak sabalik dari itu, nak ibaraik papatah adaik, urang balaia bamukasuik, niaik naza ka palabuhan. Tarang ka pulau tujuannyo, karano jalo lah sudah, cubolah kambang dinan /106/ rami, elok nak tampak dinan banyak,pulang maklum bakeh Sutan.

35. Tapi samantang pun baitu, mamandang sahuik jo saponyo. Janiahnyato batampaik tumbuah, tandonyo adaik bapegangan. Kan dek buni kato Sutan, janiahnyo salam lah baturuik, sambah jatuah lah batarimu, lah nyato hanyuik basawuang?, lah tarang hilang barambu?. Pandang sabalik dari itu, bak kato indang jo bidaran, ruah naiak mahantak, dahan patah daun lah mati, bungo bagantuang di tampuaknyo, hambo timbang mukasuik pucuak, tantu ka urek bagantuangnyo, pulang maklum bakeh Sutan.

36. Tapi samantang pun baitu, sambah jo salam kan manuju, kinilah tibodi alamaik, handai jatuah papatah datang, adaik tarang pusako nyato. Jalan nan duo lah baturuik, cupak nan duo lah bapakai, kato nan ampek di dalamnyo,sampaian cupak nan usali. Nyato dilangkuang buek taguah, lah sudah kadang dahulu, nyato dihambo mukasuiknyo. Limbak sabalik dari itu, bak handai kato 
bidaran, nan lazim wajib dituruik, nan kawi tarang dipakai, nan kawi tarangdipakai, basi batilik kan lah tarang, n-y-w manuntuik kalandasan. Kambang taserak bungo api, nak tarang bakeh nan banyak, maklum pulang bakeh Sutan.

/107/ 37. Tapi samantang pun baitu, aso pusako nan badiri, adaiknyo sambia manyambia (sambia-manyambia), dek limbago nan talatak, di sinan jajak batikam,di sinan kili baulang. Rundiang paparan hambo danga, itulah cupak nan usali, banamo gantang nan $\mathrm{y}-\mathrm{w}-\mathrm{y}$, manantang baso jo basi, salamaik mungkin naknyo tarang. Putiah jo balang nak jan tampak, hitam jo kuriak nak jan nyato, sasuai mako taganak, sapakaik mako manjadi, sakato lahia jo batin, limbak sabalik dari itu. Bak handai mamang rang Minang; umpamo kudo kalaju, buah tangan kanmanyapik, sipak palapehkan angin, nan elok dipandang rupo, maklum pulang bakeh Sutan.

38. Tapi samantang pun baitu, kato padoman nan bajalan. Handai taruih nan manuju, dapek dek hambo alamaiknyo, nan niaik hambo kasutan, dipakai <..>suruik. Nak hilang tando jo sabab, nak tarang buninyo kato, limbak sablik dari itu. Bak buni papatah adaik; ibaraik urang mamapeh, samantaro apuang-apuang hilang, tantu batenggang dialau ikan, maklum bakeh Sutan.

39. Tapi samantang pun baitu, kini lah tagak jo pusako, nak nyato karang buatan, nak tarang di ateh tumbuah, tumbuah sarupo iko kini. /108/ Rundiang sahandaikan lah dapek, kato sabuah kan lah buliah, dalam lingkuangan alua patuik. Rundiang manakiak tak manyampai, kato papatah nan manyudah, nak samo salam jo maaf, nak tibo dilanggam adaik, limbago batampek <..>, limbak sabaliak dari itu. Bak patitah cupak gantang; kilek baliyuang lah tarupo, bayangnyo tantu ka kaki. Kilek mato jo kiasan, bayangnyo tantu ka hati, nak dapek kato nan sungguah,Sutan tarimo elok sajo, sakian salam dipulangkan.

40. Tapi samantang pun baitu, bak aia disandiang pulau, karih tenggang kian kamari, riak batamu jo galombang. Ombak batamu jo daburan, arai tabaok disalodang, bungo tabao ditampuaknyo, ka gunuang edaran ka bukik, ka lurah timbunan batang, ka bukik samo mandaki, ka lurah samo manurun. Barih nan samo kabapahek, takuak nak samo kabatabang, aka manjulai bungo tibo, tampuak tabayang buah tampak, bungo nak samo dipasuntiang, buah nak samo kito makan. Bak umpamo urang batanun, suto ${ }^{61}$ tarantang gurau tibo, banang lah naiak karakutan, pasok lah samo jo sikoci. Barih balabeh nan lah cukuik, ukua jo jangko nan lah sudah, turak nak mintak dilanjurkan, maklum pulang bakeh Sutan.

/109/41. Tapi samantang pun baitu, pihak dirundiang kito kini. Kalo dikanakana bana, ditilik langgaman adaik, nan tabayang di dalam barih, takilek dalam balabeh.Takalo maso dahulunyo, samanjak gantang dibalah, sasudah cupak dipapek, rajo alim palito alam, rajo adaik rajo ibadaik, mamakai sipaik kabaikan, baiak diadaik jo pusako, mamegang kato kabanaran. Kato papatah jo patitah, kalo nan dalam

${ }^{61}$ Makananya: “sutera” (Moussay, 1995: 1108) 
samo dalam, kalo nan tinggi samo tinggi, kok mudo rundiang dalam adaik, usah mauleh tak mangasan, usah mambuhul tak mambuko, tidak nan jahek nan binaso, jabatan rundiang basauran, lah bimbang duduak malukih. Kok kusuik suri ditanun, kok rusak karuak? diguluang, lah jo puro kanji diuleh, balian turak jo kalair, batuka culuak? jo ragi, pulang maklum bakeh Sutan.

\section{/110/ Pidato Mintak Turun Tanggo}

\section{Wakatu mahantakan marapulai}

1. Sungguhpun Sutan surang nan $\mathrm{t}\{\mathrm{k}\}$ a hambo batamu, nan tapuji digala, duo rundiang nan sapatah, diakhir kato nan sabauah, takah dek lurus batujuan, dekalur patuik batampuh. Taujuik salam bakeh Sutan, titah tajelo dinan rapek, rundiang tatabur dinan rami, dilahia Sutan nan basabuik, dibatin Sutan dikandunganyo. Tampek hambo mamulangkan salam jo panitahan, adopun salam nan akan ditibokan kapado Sutan, pihak rundiangan dihari nan sahariko, alah manuruik nan sapanjang alua, mamakai nan sapanjang adaik, hulu h-n-y-t-r japuik tabao. Lah aman niaik mukasuik, santoso hati ibu bapak, lah panuah rangko hati Mamak.

Tapi samantang pun baitu, dek warih nan kito jawek, pusako nan kito rangkuah, carito nan kito danga, iyo dininik nan baduo, bagala Datuak Parpatiah duo jo Datuak Katumangguangan. Adaik balimo janyo urang, bak papatah kato adaik, bak patitah cupak gantang, tumbuh tuah dek mangato, asanyo rundiang disapakati. Dilahia lah samo nyato, dibatin basamo dilihati, budi baiak paham sadonyo, untung tak buliah dikatokan, tumbuah salasiah dek batupang, itulah aka nan cilako, /111/ tidak buliah kito pakaikan, eloklah diam dinan lapang, sambilu nan galab mambinaso, sasa jan tumbuah kamudian.

Limbak sabalik dari itu, pintak jo pinto mandatang, pihak kapado diriSutan. Sabab lah sudah minun makan, sapakaik kami nan basamu, mamintakkapado Sutan tando rila, rundiang sabuah ganti a-r-y--n, kami mamintak turun tango, suko jo rila nan babari. Diharok labiah jo kurang, kambali buni bakeh kami, sakian sajo panitahan.

Jawab untuk manahan Permintaan Alek

2. Sabanyak buah kabanaran Sutan tadi, nan kajadi sabuik jo saponyo. Di antaro kito jo Sutan, bak ibaraik urang manabang, kok batang sadang tasanda, kok dahun sadang tasakek, karupak rumbai balun batutuah, kabuang jo turiah balun putuih, supayo nak sakali rabah s-p-t mananti malah Sutan.

3. Jawab: Sabanyak buah kabanaran Sutan tadi, nak kajadi sahuik jo saponyo, antaro kito jo Sutan, ditilik kiri jo kanan, dipandang hilir jo mudiak, sudah dilihek nyato-nyato, kok batang indak nan tasanda, kok dahan indak nan tasaki $\{\mathrm{e}\} \mathrm{k}$, kabayang jo turih pun lah putuih, lah bujur tampak dikami, nan kato iyo baitu, sapanjang pintak pinto kami, lai izin jo diri Sutan. 
/112/ 4. Tahan: Sabanyak buah kabanaran Sutan, nan kajadi sahuik jo saponyo, lahtabayang bagai padoman. Takilek umpamo camin, ilang gumilang pado paham, bakandak adaik jo pusako. Limbak sabalik dari itu, nan tasuruak di ujuang muluik, nan takarang di ujuang lidah, dininiak kito nan baduo, bagala Datuak Parpatiah duo jo Datuak Katumangguangan. Kok hiduik nan kito pakai, kok mati nan kito tumpang, alah kito pangku sungguah adaik baliau janyo urang, batampek bapalatakkan, babakeh bakadiaman, mako tajadi alek jamu, kok jauah surek talayang, kok hampia(ng) siriah nan tibo. Banamo panggil mamanggil, bapakai jalang jo tampuah, baitu nan kato warih, itulah barih nan bapahek, itulah takuak nan batabang, itulah ukua nan bakabuang, sapanjang pintak pinto Sutan, raso balun kababari, basabab mako baitu, tagamang kami kalangangan hambo jo rusuah kamalapeh.

5. Jawab: sabanyak kabanaran Sutan, nan kajadi sahuik jo saponyo. Pihak rundiang kito kini, kalo dikana-kana bana, ditilik langgaman adaik, nan tabayangdi dalam barih, nan takilek lah dalam balabeh. Takalo maso dahulunyo, samanjak gantang dibalah, sasudah cupak dipapek, rajo alim palito alam, rajo adaik rajo ibadaik, mamakai sipaik kabaikan, babakeh diadaik jo pusako. Mamegang kato kabanaran, kato patatah jo patitah, nan kato iyo baitu, /113/ kalo nan dalam samo dalam, kok mudo rundiang dalam adaik, usah jo uleh tak mangasan, asah mambuhul tak mambuko, tidak nan jaleh mambinaso, jabatan rundiang basauran. Lah bimbang duduak malukih, kok kusuik suri ditanun, kok rusak karuak? diguluang, binaso turak bajalan, kasau kok ditimpo rinai, lah cupur ganjai diuleh, balain turak jo garik, batuka culuk? jo ragi, sahinggo itulah dahulunak izin jo diri Sutan.

6. Tahan: sabanyak buah kabanaran Sutan, nan kajadi sahuik jo saponyo, tumbuah sarupo iko kini, bak kato indang jo bidaran, tampuak adaik tinggi pusako, tali indang labuhan cupak, taulak indang kalabuah, tagantuang adaik kabadan, nan kato iyo baitu, ulur hentak nan lah tibo, nyato pusako lah tatagak. Nak samo marangkuhi, balun izin kami malapeh sakian sajo kapasaponyo.

7. Jawab: sabanyak buah kabanaran Sutan, nan kajadi sahuik jo saponyo, pihak dikami nan kamahanta, sagalo Pandiko jo Pang[h]ulu, sarato anak mudonyo. Kok alur alah baturuik, adaik nan kawi alah bapakai, jalan nan pasa lah batampuah. Labuh nan asa lah taturuik, tapi samantang pun baitu, bak samo surih bak mambajak, nak samo tatukik bak barunding, basamo kiro marangkuhi. Isi mupaun kandak bana, rasuk tidak ado kamungkin, /114/ sababnyo mako dimukin?. Bak pagaran maliang tanam, bak ulek si anai-anai, kiro-kiro mangirik langik, anganangan mambalah bumi, kok tidak sampai tabang ka ateh, tubuah masuk sayok marangkiah, untuang d-k-y-w awang-awang. Lah panek lihia maningadah, lah putiah mato dek mancaliak, cito-cito haram kok sampai, nan dima tak kunjuang pacah, nak jan basauak nan bak itu, sapanjang pintak pinto kami nak anyuik jo diri Sutan. 
8. Tahan: sabanyak buah kabanaran Sutan, nan kajadi sahuik jo saponyo, bak mamang urang tuo-tuo, bak manani banang lapuak, bak batanun suto basah, mangguluang banang kusuik, dicukia kok taknyo namuah, dirantang kok tak salasai, nak $<$.. $>$ basauak nan bak itu, karano hantalah taelo, bak umpamo kayu gadang, samo dilangkuang anak kayu, kok malang jatuah tatimpo, samo diuruang dikampuangi.

9. Jawab: sabanyak buah kabanaran Sutan, nan kajadi sahuik jo saponyo. Tumbuah sarupo iko kini, maniliak ereang jo gendeang, rundiang nan sajak mulo hiko, kato sabanta iko kini. Lah panek batimbang buah, puyuah pilih basarang arek, sarang gantiang tak namuah putuih, sampai tak namuah baransur buhul tak kunjuang tahurai, nak jan tasauk nan baitu, kok buliah kato nan sapakaik, kok dapek rundiang nan saukua, /115/ pintak jo pinto dilakukan. Jan lamo batang tasanda, jan talambek biduak basauah, izin jo rila kami mintak, diharap labiah jo kurang, kambali buni pado kami, sakian salam dipulangkan.

10. Tahan: sabanyak buah kabanaran Sutan, nan kajadi sahuik jo saponyo, manuruik papatah jo patitah, lah pueh batimbang kato, lah pasai rundiang basauran, pihak dipintak pinto Sutan, tahadok kadiri kami. Kok kandak balun kabuliah, pintak balun kabalaku, Sutan basentak pulang kito kabacarai-carai, hibo jo rusuah kamalapeh.

11. Jawab: sabanyak buah kabanaran Sutan, nan kajadi sahuik jo saponyo, sw-a-h jo rundiang kito kini. Umpamo kain jo sangkutan, bak urek tumbuah dibatang, bak gatah lagi kahilang. Nan tidak lapeh malapehkan, nak jan tasuok nanbaitu, pihak dirundiang kito kini, sabab lah tibo diulaknyo, dimintak jo sungguah- sungguah, nak bacangkang dari nan banyak, nak turun tanggo nan limo, <..> manjalang tampaik masiang-masiang, sakian sajo bakeh Sutan.

12. Tahan: gayuang nan kajadi sambuik, kato nan kajadi jawek, antaro kitojo Sutan bak umpamo urang manyilang, duduk bamanung, bahampehkan, bapiyuah bapilin duo, bapaliang sambia bajalan, nak dareh bantiang dilacuik, nak samo garang kasamuonyo. Nan kato iyo baniaik, Sutan nak basentak pulang, /116/kabacangkang juo nan banyak, kapai maso bak kini, kami kok salah panyangek, pulang maklum bakeh Sutan.

13. Jawab: sabanyak buah kabanaran Sutan, nan kajadi gayuang sambuiknyo, kato kajawabnyo, bak umpamo urang baguntiang, duduak di bangku tunggak ampek, dipaluik jo kain putiah, ditarik alaik jo pakakeh, sikek lalu masin manyapik, guntiang bamain timba baliak, masin manari di kapalo, rambuik baserak kiri-kanan. Ditariak gunda nan sabuah, dikambang pisau balipek, dilampihdikayu samulo, tajam nan bukan alang-alang, mandariak buni makannyo,sahambun tidak nan tingga, samiang tidak nan manyiso. Takanak ${ }^{62}$ badak jo ko basulek?, ditarik camin nan tasangkuik, dipandang-pandangi bana, tidak nan jajak

${ }^{62}$ Maknanya: "Terpasang, terkena, terletak". (Moussay, 1995: 560) 
nan binaso. Salamaik karajo dimukiaan?, lah patuik kami balapeh, izin jo rila nak dibari, sakian sajo bakeh Sutan.

14. Tahan: sapanjang kabanaran Sutan, nan kajadi gayuang sambuik kato jawabnyo. Antaro kito jo Sutan, bak ibaraik kayu gadang, ureknyo selo baselo, batangnyo sanda manyanda, dahannyo jambau manjambau, bapucuak badaun labek,.... barantiang pulo, babungo babuah ranun, lah diraih sado nan masak, lah gugur di tampuaknyo, sipaiknyo bumi manarimo. /117/ Tapi samantang pun baitu, nan mudo tingga di ateh, karareh maso bak kini, tampuak kok tagamang tingga, ibo jo rusuah kamalapeh, sakian salam bakeh Sutan.

15. Jawab: adopun kabanaran Sutan, gayuang nan kajadi sambuik, kato nan kajadi jawek dihambo. Antaro kito jo Sutan bak ibaraik urang balaia, bak babiduak disandiang pulau, tungkang kian dareh kamari. Ombak mamacah kiri kanan, bararak alun ka tapi, dibaok angin hilia mudiak, nan kato iyo baitu, dek taguah tampaik bagantuang kato nan bana nan dipacik, ujuik jo yakin dipakaikan. Dirunuik dayo jo upayo, diansua jo basilambek, manjalang tampek palabuhan,kini lah sampai ka ulaknyo. Sapanjang pintak pinto kami, iyo nak izin dari Sutan.

16. Tahan: sabanyak buah kabanaran Sutan, nan kajadi jawab pulo dihambo. Antaro kito jo Sutan bak ibaraik urang baladang, samo manjinjiang jo malatih, samo malambok? jo malamun?, ditanam bijo nan sabuah, kini lah tumbuhsamparono, batang sehaik daha salamaik. Pucuak bulek marentang panjang, kini lah samo dipayuangi, karano iyo dek baitu, dek balun pueh dek mancaliak, balun lai pasai dek mamandang, basababnyo mako baitu, karabah maso bak kini. Kok layur ditimpo paneh, balun manyuko hati kami, maklum pulang bakeh Sutan.

/118/ 17. Jawab: dikabanaran Sutan tadi, kandak nan kajadi tingkah, talampuang nan kajadi talunnyo dihambo. Manuruik papatah jo patitah, ditilik padoman alua, ditimbang naraco adaik, takilek cupak jo gantang, babayang barih jo balabeh, kironyo alua bapatutan. Tapi samantang pun baitu, dek lurus suko mailak, dekalua dituruik juo, dimintak juo pado Sutan, kato sapatah dek alur dituruik juo, dimintak juo pado Sutan, kato sapatah tando rila, rundiang sabuah ganti izin, pulang maklum bakeh Sutan.

18. Tahan: sabanyak kabanaran Sutan, nan kajadi sahuik saponyo, pihak rundiang kito kini, bak santano mato aia, talago bapantang luak, bulakan tak kunjuang panuah, makin ditimbo makin dalam, makin disauak makin datang. Diharaubatukuk janiah, lah tampak hulu muaronyo. Rundiang nan sajak mulo cako, kato sabanta iko kini, umpamo tanam saparak, samo bapucuak kasamuonyo.Kalo nan tuo manyaluruah, adaiknyo mudo mangalupak, dek balun $<\ldots>$ dinan elok, balun lai pasai dinan baiak, sakato jo mamanjungi. Sapanjang pintak pinto Sutan, balun lai manyuko hati kami.

19. Jawab: sabanyak kabanaran Sutan, gayuang nan jadi sambuik, kato nan jadi jawab. Antaro kito jo Sutan, bak umpamo urang bakain, dikaji asa mulonyo, 
di(l)ulai suto jo banang, /119/ diganti(h) basamo-samo, dirantang tanun dikumpalan, dirantiak dicukia ragi, kain sudah banang diputuih, digantiang mako dijahik, dipakai salalu hari, nan kato iyo baitu, lah lusuah banang dek mamakai, lah habi ragi dek mancaliak, kini lah patuik dipanggalai, patuik dilulus bakulimbak, sapanjang pintak pinto kami, izin nak dapek dari Sutan.

20. Tahan: sabanyak buah kabanaran Sutan, nan kajadi sahuik jo saponyo. Antaro kito jo Sutan, bak umpamo urang bagalanggang, bahimpun jananng jo juaro, ayam lapeh sabuang manjadi, tulak tundo laku ayam, coto mancotok buni paruah. Takilek banang mambulang ${ }^{63}$, badanciang bunyinyo taji, tajam nan bukanalangalang, nan tidak luko malukoi, pandai handalan kaduonyo. Kahusai maso nak kini, kalangang kami nan tingga, balun lai suko hati kami, maklum pulang bakeh Sutan.

21. Sabanyak kabanaran Sutan, nan kajadi gayuang sambuik kato jawabnyo. Antaro kito dengan Sutan, bak ibaraik bumi dengan langik, siang malam, patang jo pagi-pagi nan tidak pueh batantangan. Nyatoan bumi dari bawah,kandak sagalo isi alam, langik nan tinggi kok lai randah, alam nan leba kok lai kucuik, di sinan buhul kalai unngkai, mintak di sinan lai buliah, kok dapek pinto jokandak, izin jo rila nak babari.

\section{/120/ Pidato Uraian Kato Nan Tujuah}

Sasudah kapalo pasambahan

Kamudian daripado itu, dek bajajak Niniak kito nan baduo, nan bagala Datuak Parpatiah nan Sabatang duo jo Datuak Katumangguangan. Batinggakan kato nan tujuah, kapaikek luhak nan tigo, panyusun lareh nan duo. Adopun kato nan tujuah, partamo kato rajo kato malimpahkan, kaduo kato alim kato hakikat, katigo kato pang(h)ulu ${ }^{64}$ kato manyalasai, kaampek kato manti ${ }^{65}$ kato berhubung, Kalimo kato Dubalang ${ }^{66}$ kato mandareh, kaanam kato banyak kato bagalau, katujuah kato parampuan kato marandah.

1. Adopun kato rajo kato malimpahkan, talimpah kato ka pang(h)ulu, ragiahutang mamakaikan, tumbuhnyo iyolah di alam nan barajo.

\footnotetext{
${ }^{63}$ Maknanya: "Mengisai, menapis/ melilitkan di kepala/ mengikatkan taji pada kaki ayam yangakan disabung". (Moussay, 1995: 204)

${ }^{64}$ Maknanya: - Gelar pusaka yang diwariskan kepada kemenakan laki-laki di Minangkabau, dan tugasnyaadalah sebagai pimpinan suku dalam kaumnyall. (Saydam, 2004)

${ }^{65}$ Maknanya: - Jabatan pembantu Pengulu di bidang tata laksana pemerintahan nagari di Minangkabau,seperti memeriksa perkara, menyampaikan putusan hakim, dsbll. (Saydam, 2004)

${ }^{66}$ Maknanya: - Bertugas menjaga keamanan istana Pagaruyuang dalam sejarah Minangkabaull. (Saydam,2004)
} 
2. Nan dikatokan kato alim kato hakikat, kalo hakikat bamakrifat, nyato tarekat basariat. Dikaji kato basariat, nan lahia nan tampak nyato, nan batin putuih di Tuhan.Dikaji kato bamakrifat, ado bajalan bakeh lalu, ado bajanjang bakeh naiak, lai bapinto tampak masuak. Dikaji kato ma'rifat, walaukok bumi nan kataban,bago kok langik nan karuntuah, kabacarai nyawo jo badan, makrifat pantang diasak, situlah mako bakatokan, sariat nyato, tarekat jalan, makrifat tabuk hakikaik putuih sandirinyo.Tasabuik di dalam adaik, sarak nan babuhua mati, adaik nan babuhua sentak. Sarak nan iyo-iyo bukan, adaik nan tangga-tangga lakek. Kalo nan iyo, iyo, kalo nan bukan, bukan. Mano nan haram sajak pakai, sampai kiamaik haram juo, kalo nan ala sajak kini, sampai ka akhiraik ala juo. Artinyo adaik nan tangga-tangga lakek, sakato manjadi, sapakaik makonyo tingga.

3. Kato pangulu kato manyalasai, arti pangulu iyolah pangka dan hulu. Pangka kusuik kamanyalasai, pangka karuah kamampajaniah, nan pangulu dilihek nyato tak tampak, dihambo nyato tak babuni, tapi jalinnyo lurus, katonyo bana, hukum manyo adil, aianyo janiah, sungainyo landai. Apo bedonyo datuak jo pang[h]ulu, bedonyo iyolah ibaraik kain jo sangkutan. Kok kain ibaraik datuak, nan sangkutan ibaraik Pang[h]ulu, sapuluah kali kain dituka, nan sangkutan tatap di tampaiknyo. Tiok-tiok pangulu iyo datuak, tapi indak tiok datuak pang[h]ulu. Macam kusuik nan kadisalasaikan, dek pangulu iyolah ampek, partamo kusuik bulu, kaduo kusuik rambuik, katigo kusuik banang, kaampek kusuik sarang tampuo.

\section{kapakmahapuih.}

Kalo kusuik bulu paruh manyalasaikan, tapi kok kumuah paruah,

b) Kalo kusuik rambuik basikek, sikek mampaluruih, minyak mampalunak, mano nan tidak namuah kusuik disalasaikan. Diputusnyo disikeksikek, caro kini diretu(1) (retul) namonyo. /122/ Namonyo di dalam adaik basijanggeh (basijanggeh) duduak di anjuang. Jawi kadang mahampang labuah, nan diawak sagalo iyo, nan diurang sakalo bukan, pasa jalan bak dahulu, samak jalan nak kudian. Kalo kusuik banang bacari mato, kalo karuah bacari hulunyo.

c) Kalo kusuik sarang tampuo, iyolah ujuang jo pangka na lah hilang. Urang jo awak tak manuntuik, lawan jo kawan tak basisiah. Hukumnyo bapanggang, lah hangus sarang nan usang, diganti jo sarang baru.

4. Kato manti kato berhubung, siapun nan dikatokan manti oleh urang nancadiak cando kayo, lubuak aka gadang bicaro, tahu dikilek kato putuih, kato dibayang kato sampai. Pandai mauleh tak mangasan, tahu mambuhul tak mambuko, dipalumat kato rang kini, katonyo kato berhubung, berhubung dinan kadamai, berhubung dinan kaparang, berhubung nan kabaurai, berhubung nan kababari.

5. Kato hulubalang kato mandareh, siapun nan hulubalang iyolah urang nan babanak ka ampu kaki, bakitab Allah di langan, nan lalok siang bajago malam, kuaik nan bukan alang-alang, barani pantang mintak kawan. Tapi samantang pun baitu, bana sakali, babaso elok, babudi baiak. Kok basuo ukua jo jangkonyo, 
dapek titah dari pang[h]ulunyo. Turun tak ragu dijanjang, naiak tak ragu ditanggo, kalo karih ditakiaknyo, basuo lunak disudunyo, mano nan suto nangko, mano nan banang putuih.

/123/ 6. Kato banyak kato bagalau, artinyo kato rang dibalai, kato itu lah baitu, kato ini lah bakini. Itu gayuang tak mangandaki sambuik, kato tak mangandaki jawab, ibaraik tali alih-alih, pangajuik pipik jo tampuo, bukan pambunuah pipik jotampuo.

6. Kato parampuan kato marandah, marandah manyangkuik parintah suaminyo. Bak kuok basaok parampuan, awak ka rumah, inyo ka bawah, awak ka hilia inyo ka mudiak, ampai diawak limudiak diinyo. Pulang maklum bakeh suami.

Itulah kato nan tujuah, siang kadipatingkek, malam kadipanggalang, di luhak nan tigo, lareh nan duo. Lareknyo kato dipanjangi (dipanjangi), elok lah kato disampani, mako disampani dengan salam jo panitahan, panitahan nan kadipulangkan bakeh Sutan.

\section{/124/ Bismillahirahmanirahim}

Sajak alat samulo jadi, sajak hitam samerah kuku. Hukum arek sudah dipegang, amanaik sudah dipacik, hitam lah lakek kayudarang, merah lah tibo di sumbu sampai ka lauik ka daratan, ka ranah luhak nan tigo, dilangkung lareh nan duo. Putiah nan tidak bakotoran, haniang nan tidak bariak, alus nan tidak bapasisi. Hukum jatuah manahan bandiang, kato putuih tampek manyarah, bana nan buliah tahan sudi. Lah satimbang mungkia jo patuik, saso $<$.. $>$ lelo jo langgam, lah digalanggang cadiak jo bana, kok tasangkuik lah kanan tinggi, tasanda lah kanan gadang, tagantuang ka pucuk bulek, tahunjam ka urek tunggang.

Tapi samantang pun baitu, dilihek di aia, tabayang dalam padoman, takilek umpamo camin, tagamba dalam pusako, alua dilipek dalam barih, adaik disimpan jo limbago, riak lah tajun ka galombang, nan tasuruik di ujuang lidah, nan takarang di ujuang muluik. Dininiak kito baduo, bagala Datuak Parpatiah duo jo Datuak Katumangguangan, bak papatah kato adaik, bak patitah cupak gantang, tumbuh tuah dek sakato, asa rundiang dimufakati, nan lahir lah tampak nyato, nan batin samo dilihati.

Tumbuah barani dek saiyo, bana manukik mahantamkan, buni baik paham sadio, untuang tak buliah disarahkan, tumbuah salisih dek batupang, itulah aka nan cilako. Tidak buliah kito pakaikan, eloklah diam dinan lapang, sampik nan galab mambilasau, sasa jan tumbuh kamudian. /125/ Satinggi-tinggi malantiang, lah tibo di awang-awang, suruiknyo ka tanah juo, sahabih jangkah jo rantiang, dibukak kulik jo batang, tarik pangubak lah basuo.

Cupak di Koto Piliang, gantang di Bodi Caniago, labuah lurus jalan basimpang, limbago adaik dituruik juo. Adopun lareh Koto Piliang, barajo kadaulaik, bapucuak bulek baurek tunggang, baradat sapanjang jalannyo, bacupak sapanjang batuangnyo, bapusako sapanjang handaunyo, putuih tali putuih 
kalewaan, putuih suto tanun diguluang, tak dapek diuleh lai. Mati ayam matilah tungau, mati kuciang hilang ingau, hilang kamano kadituntuik, suri talukih dalam batu, jajaknyo tingga dalam air.

Adopun kabasaran Lareh Koto Piliang, mamakai langgam nan tujuah,partamo babasa ampek balai, kaduo bapasak kungkuang, katigo bacamin tarus, kaampek bajua mati, kalimo baharimau campo, kaanam bagajah tungga, katujuah baperdamaian.

1. Adopun nan dinamoi basa ampek balai: Tuan Kadi di Padang Gantiang, Datuak Mankhudum di Sumaniak, Datuak Indomo di Saruaso, titah di Sungai Tarab.

a. Tuan Kadi di Padang Gantiang, nan jadi kewajiban dek baliau, kok tumbuah salasiah parkarosaurang. Artinyo sah dengan bata, adopun halal dengan haram, ...sunat jo paralu, sarato makruh dengan mubah. Tuan kali punyo hukuman, hukum jatuah katonyo bana, basandi quran dengan hadis, sarato hikmah dengan kiasan. /126/ Batantukan 1-p jo maani, sarato bab jo pasalnyo, itulah palito nan tidak padam, camin nan tidak kabur, dinamoi suluh bendang Koto Piliang.

b. Datuak Mankhudum di Sumaniak, kalo nak mangaluakan pakaian di dalam alek nan bapusako, nak tiri balangik-langik, nak bunta basuji-suji, nak bapandang bataropong. Nak baikek nak basaluak.., nak cincin barangkih-rangkih, nak galang edaran tangan, basubang baantiang-antiang, piti gadang ado di sinan, dinamoi aluang bunian Koto Piliang.

c. Datuk Indomo Saruaso, kok tumbuh mangaluakan urang di dalam alek nanbapusako. Awak kumpulan ado di sanan, ameh matah tukut bubung, gantang kamudi, dinamokan puro panuh Koto Piliang.

d. Titah di Sungai Tarab, bagala Bandaro Putiah, kok tumbuah alek nan bapusako, ka sanan payuang dijapuik, nan banamo si juriang kuniang.Tembak tataran Padang Jinawi, karih sampuno k-j-w-a-y-r-h ratakmambalik ka ujuangnyo. Dianak dituruik <..> putiah. Babiso ula tampung hari, basi sabatang tigo namo, partamo basi malalik, kaduo basi malelo, katigo basi badanciang sandirinyo, sampai kapado kito kini. Payuang kuniang ado di sanan, dinamokan payuang panji Koto Piliang.

2. Ali Basa Datuak Batuah, di ranah di Sungai Jambu. Kok tumbuah /127/ urang kiliang-kiliang asam, artinyo amuh jo anggak mamakai hukum sacaro adaik, baliaulah kareh mampalunak, dinamokan pasak kungkuang Koto Piliang.

3. Sutan Pamuncak Datuak nan gadang, di Singkarak Sandiang Baka. Koksalisiah hukum manjalankan, mahukum nan sapanjang adaik, kok bengkok nan kamangadang, kok lurus nan kamanengok, ukua rajo jangko dalam adaik, naklurus rantangnyo tali, nak jan manyimpang kiri-kanan. Condong jan kamari rabah,tunggang jan kamari pai, lurus mamegang barih adaik, dinamokan camin tarusKoto Piliang. 
4. Sutan Batuah Datuak Majo Bangso, di Sulik Aia Tanjuang Baliak. Kok batangguah urang mamakai hukum nan sacaro adaik, aratinyo duduak di jalan tagak di janjang, banamo si mungkir nan anggan dinamokannyo mati Koto Piliang.

5. Tuan Gadang di Batipuah, kok basuo jo urang nan bagak, nan bakitab Allah dilangan, babanak ka hampu kaki, babaju ka ujuang kuku, batarih ka tapak tangan. Mamanggakkan bidang bahu nan kuaik, malanyutkan tulang tak babanak. Nan bataratak bakoto asiang, mahandaian bakato surang, mahariak mahantam tanah, mambulalak mambulalang, manyirahkan incek mato. Kok baso nan sado itu, kok karih nan kamanukiak, kok lunak nan kamanyudu, tuan gadang punyo kuaso, dinamokan Koto Piliang $<\quad>$

6. Di Silungkang Padang Sibusuak, itulah urang nan tidak mampadulikan hari kalam, nan tidak ngari manampuah guruah, /128/ guruah jo patuih, ujan labek nan kareh daripado batu, nan tajam daripado basi, nan biso daripado ipuah, nan tangkeh ${ }^{67}$ daripado kilek, nan geger daripado patus, dinamoi gajah tangka? Koto Piliang.

7. Kok tumbuah bantah jo kalahi, sarato silang jo salisiah, atau nak samo batuhuak ${ }^{68}$ padang, dari nagari ka nagari, sangketo nan tidak habis, dandam kasumaik nan tak putuih, mangko dihabisi dengan baiak, dibaka kumayan putiah, asok mandulang ka udaro. Dimulai jo lidah aia, disudahi jo lidah api, dibacokan p-w maso itu, sarato dikatam dengan doa. Di Simauang Bukik Kandung, itulah nan banamo medan perdamaian Koto Piliang.

Adopun lareh Bodi Caniago, barajo ka mufakaik, bapucuak nan manjulai, baurek nan manjangka. Adaik balingkaran, pusakonyo bakahiliran, gantangnyo bakaliaran, putuih tali buliah diuleh, putuih suto uleh jo banang. Banang lah jadi suto pulo, habih anau tingga di hutan, biluluak lah jadi anau pulo. Suri tarantang basangkutan, jajaknyo tingga dinan banyak, khalifah pakai mamakai, adaik tali batali, warih jawek manjawek, pusako tolong manolong. Adopun warih duo baginyo, partamo warih batali sawang, kaduo warih batali adaik.

Warih nan batali sawang sabuah paruik, sahiliran tali darehnyo, arti warih batali adaik, panjang rantang talinyo, banyaksapihnyo. /129/ Baliau bagalanggang tanah, tuahnyo dinan sakato, cilakonyo dinan basilang, buleknyo dinan sagiliang, pipihnyo dinan satapak, bulek nan tidak basagi, pipih nan tidak basuduik. Nan tapauik makanan lantak ${ }^{69}$, nan takuruang makanan kunci, kalo mamahek manuju barih, di mano bayang nan katabuak. Manabang manuju batang, dimano bana nan karabah, malantiang manuju tampuak, diagak buah nan karareh, tantang aia malapeh tubo, dakuh ikan nan kamati, rundiangnyo banyak nan bakieh,

\footnotetext{
${ }^{67}$ Lihai, hebat (Moussay, 1995: 1145)

${ }^{68}$ Tohok (Moussay, 1995: 1199)

${ }^{69}$ Maknanya: - Batang, tiang, pancang, patokll. (Saydam, 2004)
} 
katonyo banyak nan <..> nan karabah, nan baukua nan bajangko, nan bacupak nan bagantang.

Adopun kabasaran lareh Bodi Caniago, batanjuang nan tigo, balubuak nan tigo, partamo Tanjuang Sungayang, kaduo Tanjuang Alam, katigo Tanjung Barulak. Adopun lubuak nan tigo, partamo lubuak Siputi sabalah ka Sijunjuang, kaduo lubuak Sigarah sabalah ka Solok, katigo lubuak Simawang sabalah kaTalawi. Lah kawi adaik di Nagari, lah lazim tarang di alam, pusako di korong kampuang, agamo di Nabi kito, firman mangato di Quran, hadis batulih dalam kitab; Ati'ullah wa ati'urassul wa ulil amri mingkum, ikuik olehmu akan Allah dan ikut olehmu akan Rasul dan urang yang memerintahkan kamu diikuik suruah, dihantikan tagah, diikuik suruah, dihantikan tagah, dikarajokan rukun nan limo, dibuek amal jo ibadaik. Diucapkan kalimaik nan duo patah; Ashadullah illahhaillah waashaduanna muhammaddarasulullah, lah hiduik nan kadipakai,kokmati nan kaditimbang, di sinan dapek tali taguah, kito bagantuang lahir batin.

/130/ Denai paham dalam tubuah, paham insaf paham nan nan haniang, paham sangko candorong tapi, paham s-a-k barisi antah, paham waham mambao lalai, paham yakin ilmu tanak. Ujuik satu pangana bunta, diagak-agak dipikiri, pikir itu palito hati, tanang sarugo aka, haning hulu bicaro, dalam sabar bana mandatang. Hemat-hemat dahulukan berhemat-hemat kamudian, paham arif balawan baik, paham cadiak manganai surang, paham manti mangubah bingkai. Bijaksano tahu dirasam $^{70}$, cando kayu pandai maukua, bayu parai pantun ibarat, jo hari tahu dimanikam, budiman $\langle\ldots$, $>$, sandek di hati muluik mangatokan, nyato adaik di ateh tumbuah, nyato pusako baungkiran. Limbago sunah mananti, indang maisi kandak, cupak basilaku panuah, gantang $<$.. $>$ jo lelo, jangan maluak mausaki. Elok di dalam janji mulia, dilangkuang buek nan bakarang, langgam adaik bateh tumbuah, galanggang baampang limo, alek jamu basipangkalan, tumbuah sarupo iko kini.

Adaik limbago urang barundiang, dipaiyo dipatidokan, dipaulur dipajangkokan, lah <..> batimba baliak, barulah panjang dibari barueh, sangkek dibari babuku, namun salorong nan bak kini, alah bamakam banasabah, adaik badiri kadipakai, cupak tatagak kadiisi, limbago tasakah kadituang, barih takanak kadipacik, tagok balingkar kaditabang, jalan nan asal kadituruik, labuah nan pada kaditampuah, sumua taganang kadisauk, rantiang tajulai kadipatah, suri tarantang kaditanun, kini nan putus kadiuleh.

Mako dicarilah hari nan baiak, maso kutiko nan elok di dalam bulan nan duobaleh, di dalam tahun nan duo lapan. Bahituang /131/ hujarat jo takwim, dibukak katanyo kulimo, dibilang galah salapan, dilihek dalam susuik? runuik, lah tibo dihari nan baiak, maso katiko nan elok, dihari nan sahari kini, disiko niaik disampaikan, sarak mambarek ateh cupak, adaik batangguang pado mamak, namun baitu nyolai kini, kalo hiduik di ateh dunia, ibaraik basi nan bapaantang patah, nan bamato sumbiang, nan bapucuak layua, nan banyawo maraso sakik ngilu paniang, labiahnyo mati di atehnyo. Sasuai dengan parintah Allah; kullu

\footnotetext{
${ }^{70}$ Adat kebiasaan (Moussay, 1995: 949)
} 
nafsun daaikatul maut, tiap-tiap nan banyawa marasoi mati. Aynama takunu yadriikumul mauta walau kuntum fii buruji musyayyadah, di mano kamu baradopasti mandapati jo akan mati, walau di dalam karando kayu sakalipun.

Adopun adaik islam mati, dipasang alam ${ }^{71}$ jo marawa, banamo renodalam kampuang, banderang ka langik cahayonyo, mako dibunikan buni-bunian, dilacuikkan tabuah, dilatuskan badil, badil malelo buatan Japun, ratak malikok ${ }^{72} \mathrm{ka}$ ujuangnyo, kok basalah datang dari urang, kok bana datang dari awak, alun dipatiak lah badanciang, alun disunu lah malatuih, adang manjadi karih pendek, sampai ka kampuang dibakanyo.

Tembak rang Taeh si Malenggang, pandai mambilang <..>, pandai maningkek anak janjang, samangkir-mangkir rang manembak di baliak gunuang kanai juo. Daripado itu mako dibunikan gandang si Rajo Nubah, /132/ ka Padang Parpatiah nan Sabatang, buninyo talun batalun, mandarang salingka gunuang, manggaga salingka bukik, di gua aguang Datuk Katumangguangan. Buni sarangak rangau kampuang. Buninyo jauah-jauah hampir, buninyo tinggi-tinggi randah,adang tadang ateh langik, adang tadanga di udaro, adang babuni sayok buruang, haram barasok di talingo.

Kamudian daripado itu, dikambangkan kain kili-kili, kain jajaan sampai ka labuah, osongan talatak di halaman nan banamo si majo pacik, ditagakkan pulo payuang gadang, nan banamo si jurek kuniang. Tatagak tataran sabagai japutan, tasanda parisai kilek s-j-w mako dilangkapi pulo kalangkapannyo, kapur candano kayu garu, kumayan putiah dari barus, limaunyo kapeh tampuak hari, limau sabatang tujuh ragam, kapehnyo putiah reno hati, kambang bak awan tagantuang. Ambiak cangkir katimbo mandi, <..> nan amaik halus, kain kapan nan amaik putiah, kainnyo ganiah baru aji, halus bak sayok layang-layang. Namun sahari nantun pang]ulu datang manjanguak, hulubalang datang mahanta, urang banyak datang mahiriang. Dihantakan basamo-samo ka tanah nan amaik mulia.

Disambahyangkan imam dengan katib, ditanamkan bila $^{73}$ jo malano, ditutuplah dengan papan nan suji, ditimbuni dengan tanah nan barasiah, ditalakinkan oleh pandeto, dihantakan ka hadirat Allah nyo, iradah Allah kok iradah ham. Kahandak Allah labiah tinggi dari kahandak mereka itu. Faiza jaa'aajaluhum la yastakqirun saa ng'ata wala yastakdimun; apabilo datang ajalmereka itu tidak terdahulu sangatpun dan tidak pulo terkemudian. Adopun baliau nantun, panjang langkah lah singkek /133/ permintaan, lah terdahulu baliau daripado kito, jikok buliah pinto jo kandak hidup bulih baliau sapakan duo pakan, sabulan duo bulan atau satahun duo tahun, laikarano baliau nantun lauik akal

\footnotetext{
${ }^{71}$ Alam, daerah, negeri (Moussay, 1995: 25)

${ }^{72}$ Menyorok (Moussay, 1995: 719)

${ }^{73}$ Maknanya: - Bilal, tukang seru untuk mengerjakan shalat dengan mengumandangkan azan)\|. (Moussay, 1995: 178)

${ }^{74}$ Maknanya: - Peribaha yang mengandung arti sebagaipegangan dalam hidupgian kalimat yang masing-masing terdiri dari dua sampai empat buah katall. (Moussay, 1995: 760)
} 
gudang bicaro, cadiak pandai arif budiman, hukum adil katonyo bana, kapai bakeh rang batanyo, kapulang tampek mangadu dek anak kamakan baliau.

Tapi samantang pun baitu, tak dapek sakambuik padi, sakambuikditumbuak luluah. Tak buliah nan katidakhati, kandak Allah hanyo nan sungguah, karano lah bapulang baliau karahmatullah. Lakiklah mamang ${ }_{74}$ rang di Minang; kamano jalan kabalai, ka rumah rajo di ruhun, pulai nan bap $\{\mathrm{t}\}$ angkek naiak, mansai nan batanggo turun. Kalo pulai nan bap $\{\mathrm{t}\}$ angkek naiak, mambao runah dengan buku, badaun bataruak mudo, manyusun dahan dengan rantiang, manaruahbuah dengan bungo, kalo mansai batanggo turun, mambaokkan barih jo balabeh. Mambaokkan cupak jo gantang, mamakai adaik jo pusako, adaik nan sapanjang jalan, cupak nan sapanjang batuang, saabih nan dibilang-bilang, basurek nan dibaco-baco, sabarih tidaknyo hilang, satitiak tidaknyo lupo.

Nan bajanjang naiak batanggo turun, nan batiru batuladan, nan babarih babalabeh, nan bacupak nan bagantang, nan baju bajukalo, nan $<\ldots>$ nan bapakai. Basusuak bajarami, bapandam bapakuburan, kok jauah buliah ditunjuakkan, kok hampir bulih $<$.. > . Warih utang manjawek, pusako utang manolong, dari Niniak turun kamamak dari Mamak turun kakito, kitolah utang mamakaikan. /134/ Apolah warih nan kakito jawek, pusako nan kito tolong, bak handai kato bidaran, anak sutan pandai mambilang, sampai mambilang baru aso, acuan hanyo nan hilang, pusako baitu juo, lah mati udang rago masilah? mamegang sapiknyo, lah hilang baliau nan tuo, nan mudo manjawek warihnyo. Lai saruik dinanti talang, kapohon sambil k-y-w, sakek sakai tinggi-tinggi di bawah padang batiah-batiah, lai ketek dinanti gadang. Mahukun kok tidak adil, lakek lah rantai kini-kini,dinamokan sumpah Parpatia.

Kayu gadang di dalam banda

Pilin aka katalinyo

Urang gadang kok tidak bana

Pintu narako manantinyo

Ka mano tabang taraguahKa

rumah Sutan Batuah

Hinggoknyo di p-l-w mapakan?

Kalo kaganta-ganta takuik

Nan patah manjadi tuah

Tuah manjadi pandapatan

Di mano kalapung? nan babuah

Babuah di dalam padi

Lah hilang baliau nan batuahLah

baganti jo nan mudo kini

Ramo-ramo sikumbang janti Katik

endah pulang bakudo Patah

tumbuah hilang bagantiPusako

randah kawarihnyo 
Tumbuah sarupo iko kini, karano hilang kadiganti, patah kaditumbuhi, baju balipek kadisaruangkan, gala pusako kabasaran kaditaslimkan. Adaik badiri kadipakai, cupak tatagak kadiisi, limbago tasakah kadituang. Barih takanak kadipahek, takuk balingka kaditabang, supayo tagak nak jan tasundak malenggang nak jan tahampeh. Ditantangan carano nan ka tangah, mano pasanan biaso, diadaik nan kito pakai, dipusako nan kito rangkuhi, putiah kapeh buliah dilihek, /135/ putiah hati bak aduan. Kalo barih manahan tilek, balabeh manahan cubo, kok tidakdibarih pahek makan, kok tidak batokok tabang tibo, artinyo panuah koknyomalimbak, kurang kok nyato badakuak, nak balihek balengong, diangko di ateh satimbang satarimo, lembak sabalik dari itu. Kok alah dibarih makan pahek, lah ditakuk tabang tibo, panuah nan tidak malembak, kurang kok indak badakuak, nakbatarimo suko diangku, jo muluik nan manih, hati nan suci. Sakian salam dipulangkan, diharap buni nak kambali.

/136/ Syarat Urang Manjadi Panghulu

Urang yang akan diangkat jadi panghulu itu haruslah manurut nan biaso dalam adaik

1. Labih berakal dalam urang nan sakaum, sarato mangatahui hukum akal nan tigo parkaro, nan wajib pado akal nan mashul pado akal, nan harus pado akal.

2. Laki-laki yang [p]aling berakal.

3. Urang nan barasal jo dari panghulu berhak memakai dan mewarisi panghulu itu

4. Ber'ilmu.

5. Tahu akan saluak baluak adaik limbago urang di dalam nagari dengan...

6. Kayo harato bando dan dalam ilmu akalnyo.

7. Murah lakunyo yakni jangan kagadang-gadangan, tinggi hati, adab kapado urang lain, panya yang berhati rahim kapado rang nan taraniayo.

8. Murah laku pihakberkato-kato, fasih lidah manih muluik.

9. Jago pado sagalo pekerjaan sepanjang adaik, labiah sepanjang sarak

10. Lapang dan sabar hati, jangan pemarah melainkan wajib melakukan tipu

Muslihat dan pengajaran yang baik-baik, manunjukan jalan yang lurus kapado

kaum karabatnyo;wakhfish janahaka liman tabaaka, randah kanlah akan sayok

engakau kepada siapa-siapa supaya mengikut dia akan engkau. 


\section{/137/ Kapalo Pasambahan Palsapah Pakaian Panghulu}

Manolah Niniak Mamak hambo nan gadang basa batuah, pucuk bulek jo urek tunggang, kaampek suku di nagari, nan manjunjung sako ${ }^{75}$ adaik, nan mamacik bayang tabuak, nan mangganggam gantiang putus. Manolah Imam Katikdengan Bila, Malano jo Tuangku, nan duduk jo 1-p jo Maani. Nan mamacik buku sariat, nan mamegang hukum Kitabullah, ikutan urang di nagari. Hiduik kabakeh urang baniaik, mati ka tampek rang bagau, kapado urang Cadik Pandai, jo Manti Pagawai adaik. Urang nan cadiak candikio, muluik manih bak pauah koto, pandai mauleh roman putus, uleh panjang indak mangasan, buhua pendek pantang mambuko, padoman tarus dek nagari. Limbak sabalik dari itu, Hulubalang jo ampang limo, bagak nan bukan alang-alang, barani pantang mintak kawan, pahunidusun jo taratak, pagaran koto jo nagari. Gali jo tangan dipang(h)ulu, urang mudo pambimbing dunia, ipa bisan samo di dalam, namonyo urang ampek jiniah, dilangkuang pasambahan kasamunyo.

Awal kalam mulo rundiangan, salam takzim dari hambo. Sidang rapek jaweklah tangan, di batin salam ditarimo, /138/ ampun sagalo Niniak Mamak nan gadang basa batuah, kok salah maaf dipabanyak, nan khadim ${ }_{76}$ hanyo sifat Allah. Kito nan bukan cadik pandai, ilmu di Tuhan tasimpannyo, kok senteang mintak dibilai, tandonyo kito sahandiko.

Mancaliak kajalo zaman, edaran maso putaran alam, lah habih jaman panjajahan, patuik disilam nan tabanam. Sampai buya tanah air, lipur di zaman panjajahan, kini lah jadi buah pikir, sadang di dalam panggalian. Kito dalam Minangkabau, lah patuik tasentak pulo samaso balun talampau, patuik dirunuik sitambo lamo. Niniak moyang luhak nan tigo, mambuek barih jo balabeh, bulek dituah lah sakato, nak tantu hinggo jo bateh. Ujuik tujuan buah runding, sakiro paham dikandaki, maso nan ditampuah, musin nan tumbuah kini nangko, dalam nagari nan merdeka, cinto baiak pangana elok, basamo manuju kemajuan, dalam bagian masingmasing.

Kini lah samo dilakukan, mambangan dalam nagari, ditiok bagiannyo /139/ lapangan, di bidang kito surang-surang, sabab karano nan bak kian, timbullah cinto dalam hati, nak mauraikan zaman nan lampau, kebudian alam Minangkabau, di dalam luhak nan tigo, suatu lareh nan duo, dibidang barih balabehnyo. Caro di zaman nenek moyang samaso adaik lai kawi, sabalun dijamahdek Ulando. Tapi samantang pun baitu, pihak di badan diri hambo, bukanlahurang cadik pandai, tidak dapek dipandang mato, bukan tabik dek buah pikir, hanyolah warih nan dijawek, umanat guru nan dipacik, kaba nan dari rang dahulu, jawek bajawek sampai kini.

Salain daripado itu, hambo jinjiang kato pasambah, buah pikir ramalan batin, pakaian urang jadi Pang[h]ulu, bak karandam kato adaik, rupo mangato kan harago, kurenah manunjukkan laku, sungguah nan lahir tampak dek mato, nan

75

Maknanya: - gelar pusaka yang diwariskan kepada generasi penerus dalam adat Minangkabau, dari mamak turun kepada kemenakanll.

${ }^{76}$ Maknanya: -terdahulull. 
batin tasimpan dalam itu. Sariaik ado hakikatnyo, tarekat ado makrifatnyo, lahia kulapat manganduang isi, di lua nan tampak nyato, di dalam pandang ilimu, niak nyato paham maminjek, dijuari jo tasimpannyo. /140/ Kalo dipiliah jo pikiran, jikok aka dipajalankan, jo tanang budi marangkak, kateh lai tahambun juntau, ka bawah lai bakasik bulan, sampai tapakai ka ilimu, lahir manjadi buah amal.

Dek ungkiran sako nan tatagak, koto aman alam santoso, salamaik korongjo kampuang, mahambur? anak kamanakan, dunia buliah akhiraik dapek, sinan merdeka mako panuah. Dek yakin hambo tantang itu, di siko dicibo mauraikan palsapah pakaian urang pang[h]ulu, andiko adaik di nigari, nan manjunjung sakojo sang? sako untuk nak samo di dalami, nan kurang samo ditukuak, nan rumpang samo disisik, supayo nak panjang nak bauleh, tibonyo leba dek bakampuah. Kok lai bak kato falsafah, mambikin jo patut baukuran, isi kulek sarupo lahir, ganggamarek pegangan taguah, tibolah lukih jo limbago. Hancua siriah manjadi sapah, kaleknyo tingga di rangkuangan, sirahnyo tampak di bibia, pareso maruang tutuah

$<\ldots>$ angkuik kato jo hanyo.

\section{/141/ Palsapah Pakaian Panghulu Minangkabau}

\section{Oleh b Datuk Nagari Basa Payokumbuh}

1. Deta $=$ saluk

Badeta panjang bakatuak, bayangan isi dalam kulek, panjang tak dapek

diukua, leba tak dapek dibilai ${ }^{77}$, salilik lingkaran kaning, ikek satuang jo kapalo. Tiok katuak baundang-undang, tiok liku aka manjala. Dalam karuik budi marangkak, tabaok dek paham tiok lipek. Lebanyo pandendang kampuang, pandukuang anak kamanakan, hamparan di rumah tanggo, paraok gonjong nan ampek. Di halaman manjadi payuang panji, panuduangi korong jo kampung.

Sarekat warih mandirikan, bakeh balinduang hari paneh, tampek bataduh hari hujan, dek nan sapayuang sapatagak, nan salangkuang cupak adaik, nan di bawah payuang nan sakaki, sarato tembak nan sabatang.

\section{Baju}

Babaju hitam kudarang ${ }^{78}$ langan, langan tasenseang tak pamberang, bukan

karano dek pambangih. Pangipeh angek naknyo dingin, pambuang kabuik naknyo habih, siba79 batanti timba balik, mangilek mangalimantang, tutuik jahik pangka langan, mambayangnkan uleh tak mambuko, pandai mambu hul tak mangasan. Laut ditampuh tak bariak, /142/ padang ditampuh tak barangin, budi halus baklaut dalam, dalamnyo pantang kaujuan, dangkek nan tidak kasabarangan. Pasia mangapuang pantangannyo.

Langan basisir kiri kanan, b-m-y-l-z mako k-z-m-n-s-k, gadang barapek jo nan ketek, alamaik urang gadang bapangiriang. Tagak baapuang jo aturan, adaik

\footnotetext{
${ }^{77}$ Maknanya: —disambung, diulasll. (Moussay, 1995: 178)

${ }^{78}$ Maknanya: - kain yang ditambalkan pada bagian dada tempat kancing bajull.

${ }^{79}$ Maknanya: - pinggiran baju, sambungan badan dengan lenganll. (Moussay, 1995: 1057)
} 
limbago nan mangapuang, baukua jambo jo jangko, h-n-j-z baagak bahangkukan. Murah jo maha mambatasi, martabat nan anam dipakaikan. Lihianyo lapeh tak dikatuak, babalah hampia ka dado, manyatukan alamnyo leba, padang lapang buminyo laweh, gunuang tak runtuh digayuik, lauik tak karuah diikan. Urang gadang martabatnyo saba, tagangnyo bajelo-jelo, kanduanyo badantiang-dantiang. Pahik manih pandai malulur, cando kaiyo kasesonyo sinan, martabat maampunyo.

\section{Sarawa}

Sarawa hitam kudarang kaki, kapanuruik halua nan lurus, kapanampuah jalan nan pasa, ka dalam korong jo kampuang, masuak ka koto jo nagari. Langkah salasai baukuran, martabat nan anam mambatasi, murah jo mahal di tampaiknyo, baiyo mako bakato, batolan mako bajalan. Bajalan surang tak dahulu, bajalan baduo tak di tangah. Hemat-hemat lah dahulu, dimartabat kalimo haram koklengah. /143/ Tanah kudarang dinan hitam, paham hakikaik tahan tipu, manahansudi jo siasaik, kuma? bapantang kalahiran, kukuah manganggam nan $<$.. >.Pahamnyo jago dibacaro, kajadi ancik hambo manyawuik, itu nan jadipantangannyo.

\section{4. $\quad$ Sisampiang}

Sisampiang sabidang ateh lutuik, kayo jo miskin alamaiknyo, ado batampaik kaduonyo. Luruih santiang tak bulih dalam, patuik dalam tak buliahsantiang, karajo hati kasamunyo, mungkin jo patuik baukuran. Tanahnyo merahbacukia makau, tando barani dinan bana, _ilmu bak bintang bataburan, sumarak katangah koto, manjanyo masuak nagari $\overline{\bar{d}}$ alammartabat nan katiko. Kayo hati jomiskin hati di ateh jalan kabanaran, namun nan baiak nan dimintak, sabab taktimbua dipang(h)ulu. Alun bakandak lah baisi, alun mamintak lah babari, tapi koktuntutan kanan buruak, dilewa adaik jo limbago, baratuih nyato panarawang. Tatagak paga nan kukuah, parik taba bantang mahalangi, dihampangnyo lalukasubarang, badindiang sampai ka langik, haram kandak bapalakukan.

\section{Cawek}

Cawek suto bajumbai alai, saheto pucuak rabuangnyo, /144/ jumbua nan tangah tigo tampuak. Kapalilik anak kamanakan, pangabek aka budinyo,pamawuik pusako datuak, nak kukuah lua jo dalam, nan jinak nak makin tanang, nan lia jan tabang jauh. Kabek sabalik buhua sentak, kukuah tak dapek diungka, guahnyo bapantang tangga, lungga bak dukuah di lihia, babukak mako kaungkai, jo rundiang mako katangga, kato mufakaik [kapaungkai].

\section{Sandang}

Di bahu manyandang kain kaciak, kain cindai ampek pasagi, pahapuih paluah di kaniang, pambungkuih nan tingga bajapuik, pangampuangan nan tacicia babinjek, kato dahulu batapi jo kato kudian kato bajadi, tak buliah tidak janyo adaik, tandonyo Tuhan basipaik qadim. Dirantai kunci tagantuang, babagai bantuak ragamnyo, marupokan alaik jo pakakeh, banyak salapan baleh buah. Kalo ditanyo alamaik kini, iyolah kok tibo dimaso kayo, dibukak peti kabaragih, kok tibo dimaso miskin, panganja puro nak bahemaik, kalolah dimaso murah, 
mambukak peti pakaian, panuruik alua nan luruih, kapanampuah jalan nan pasa, nan lah tibo dinan maha, nak kukuh simpanan dek kuncinyo, kalo diadat nan bapakai, datang panjang Simajolelo, kalo pusako, panyangkuk sampa, pambukak peti bunian, baiak digantang nan /145/ tatagak, sasudah gantang dibalahpanyangkuik sampa nan adaik, panyimpan kato kabulatan, nak kokoh barih jo balabeh.

\section{Sanjato}

Sanjatonyo karih kabasaran, sampiang jo cawek nan tampaiknyo.

Sisiaknyo tanam tabukan, batangnyo condong ka kida, dikesong mako dicabuik. Banamo balam kahinggok, gempoknyo tumpuan puntiang, tunangan hulu kayu kamaik, kokoh tak ragu diambalau, guyahnyo bapantang tangga, bengkoknyatangah tigo patah, tapi luruih makanan banang, bantuak dimakan siku-siku, bamato balik batimba, sajawek pulo jo ganjonyo, pantang balampeh kaasahan- tajam tak rago bagabuih, mamutus rambut dihambuskan, tapi bapantang malukoi, kaparauik lahir jo batin, pangikis miang di kampung, panarah bungkung sajangka, kapanyisiak parik jo hulu.

Ipuahnyo turun dari langik, biso bapantang katawaran, jajak ditikam mati juo, kapalawan dayo urang halus, panulak musuah nan dibadan, jalan sjai'ah nan jan taturuik, sampai bak handai jo bidaran.

Karih sampono ganjo erah

Lahia batin pamaga diri Patah

muluik tampaik kalahPatah

sanjato bakeh mati.

/146/ 8. Pamenan- Tungkek

Pamainannyo tungkek kayu kamat, ujung tanduk kapalo perak, panungkek adaik jo pusako, barih tatagak nak jan condong, sako nan kukuah diingkiran, ingek antaro balun kanai, kulimek antaro balun habih, gantang nak tagak jo lanjuangnyo, $<>$ adaik nak tagak jo limbago. Palsafah pakaian jadi Pang[h]ulu,

di dalam alam tanah Minang, kalo umbalo maranak hulu, pantiang tangga mato tabuang. Kalo kulik manganduang aia, lapuak sampai kapangubak, binaso tareh nan di dalam, jiko Pangulu bapaham cair, jadi s-m-n-z alam nan leba, lahir batin dunia tanggalam.

\section{/147/ Pembagian Luhak Nan Tigo Dan Rantau Nan Duo}

Adopun Luhak Limo Puluah di dalamnyo tigo bahagian, partamo banamo luhak, kaduo banamo ranah, katigo banamo lareh. Luhak nan banamo luhak, sajak dari Simalanggang sampai ka Taram. Nan banamo ranah, sajak dari Simalanggang sampai ka Tabiang Tinggi. Nan banamo lareh sajak dari Taram sampai ka Pauh Tinggi. Dari Luhak Limo Puluah manurun pulo ka Kuok, ka Bangkinang, ka Salo,ka Aia Tirih sampai ka ranah ka Rumbio. Rantau nan limo itulah nan disabuiklimo gayuang aia, nan barajo kabanda basiak, babapak Kalimo Puluah, bamandi Kapalo Ruyuang, babalai kapangkalan Koto Baru. 
Adopun nan banamo luhak di luhak Limopuluah, masuk di dalamnyo Suayan, Sungai Balantiak, Sariak, Tambun Ijuak, Koto Tangah jo Batu Hampa, Durian Gadang, Babai, Koto Tinggi, Air Tabik, Sungai Kamuyang, Si Tujuah, Banda Dalam, Limbukan, Padang Karambia, Sicincin, Aur Kuning, Tiaka, Payobasuang, Taram, Bukik Limbuku, tigo jo Batu Balang, Payokumbuah Koto nan Gadang.

Nan banamo ranah dalam luhak Limo Puluah, masuak di dalamnyo Gantiang, Koto Laweh, Suliki, Sungai Rimbang, Tiakar, Balai Mansiro, Taeh, Simalanggang, Piobang, Sungai Baringin, Gurun, Luhak Batingkok, /148/Torantang jo Sari Lamak, [Solok][Bio-Bio] jo Padang Laweh. Adopun nan banamo lareh di dalam luhak Limo Puluah, masuak di dalamnyo Gadut jo Tabing Tinggi, Sitanang Muaro Lakin, Halaban jo Ampalu, Surau [jo] labuah gunuang.

Urang Kubuang Tigo Baleh turun pulo ka Padang, Pauh Koto Tangah, Bayang, Tarusan, Salido hinggo Air Haji, dari Luhak nan tigo itulah mahilir ka rantau nan banamo rantau mudiak jo rantau hilia. Adopun nan banamo rantau hilia,iyolah nan sabalah ka Timur luhak yaitu sabalah Muaro Takung Hilir. Tanjuang Simalidu Mudiak dan Pulau Punjuang, Siguntur, Sungai Jambu, Lubuak Ulang Aliang, Durian Silung, Lubuak Gadang, Nangko, Aka Japang, Lubuak Malako, Bidarak Alam, Muaro Ikuang, Abai jo DusunTangah, Sungai Kunyik jo KotoRambau sampai ka Buluah Kasok, sahinggo Durian Ditakuak Rajo. /149/ Kamudian sabalah ka Kampa, iyolah Kampa kiri jo kampa Kanan, Pangakalan, Gunuang Sahilan, Kuantan jo Batang Hari, Siak ka Indogiri, sampai ka Tanah Malako, tasabuik jo sampai kini, banamo rantau Minangkabau baradaik pusako turun kakamanakan, baitu Negeri Sembilan di Malaya.

Nan banamo rantau mudiak iyolah sabalah ka barat, yaitu Pasisir Nan Panjang, Kualo, Taluk, Labuhan dari Lautan dari lautan Indopuro sampai Kabanda Nan Sapuluah, di dalam nyo tasabut Bayang, Puluik Puluik, Taratak, Tarusan, Lumpo, Salido, Painan, Batang kapeh, Surantih, jo Ampiang Parak, Kambang, Lakitan, Sungai Tunu jo Pungasan, Air Haji Sampai ka Indopuro.

Nan banamo tigo luhak iyolah Tapan, Lunang, Silauik, sabalah utaro sampai ka Taluak Labuahan Tigo, lalu ka Rantau Sikudidi, rantau tigo jo Pariamanjo rantau Pasaman, di alamnyo Padang Ulak Karang, Pauah jo Koto Tangah, Sintukjo Lubuak Aluang, Toboh jo Pakandangan, Ulakan jo Kurai Taji,Tujuah Koto jo Salapan Koto, Tiku Jo Pariaman, Lalu ka Sikilang Aia Bangih, Gunuang Malintang, tarus ka Tanah Darek, Panti, Rao, Lubuak Sikapiang lalu ka Batu Basurek, Sialang Balantak Basi, ka Gunuang Patah Sambilan, sahinggo Durian Ditakuak Rajo.

\section{/150/ Adaik}

Adopun adaik itu babaju, baurek tunggang, babatang tareh, bapucuak bulek. Babaju adaik iyolah budi nurani, urek tunggang adaik yaitu raso pareso, pucuak bulek adaik angku katik tango, batang tareh adaik halua patuik jo mungkia.Landasan sandi adaik, dasar hukum adaik, yakni awal baparmuloan, partangahan baparantian dan baakir bakasudahan. Budi nurani yaitu suatu s-y-r daripado maha p-n-y-p-t alam, nan manjadi sabab parmuloan. 
Baju adaik, yaitu satu detikan hati dan detikan jantuang nan manjadi awal permulaan. Urek tunggang adaik, raso baitu suatu garik raso perikemanusiaan dan budi baik, nan manjadi pertengahan parantian. Batang tareh adaik pareso yaitu suatu k-r-k penilaian cito nan dilahiakan oleh raso, nan manjadi akhir kasudahan. Pucuak bulek adaik, halur, yaitu kabanaran dengan kenyataan dan satu rencana peraturan nan manjadi awal permulaan. Urek tunggang adaik patuik, yaitu malatakkan suatu pado tampeknyo nan manjadi pertengahan parantian. Batang tareh adaik mungkin yaitu kewajaran mempastikan suatu hal nan manjadi awal permulaan. Urek tunggang adaik /151/ katik, yaitu janjang, suatu alaik penghubung nan manjadi pertengahan perantian.

Batang tareh adaik: tanggo, yaitu rumah nan sudah taratur atau peraturan nan sudah tersusun nan manjadi akhir kasudahan, pucuak bulek adaik cito, halur, angko, yaitu dibanarkan oleh datak datik hati yakni perbuatan lidah pertengahan parantian. Sandi hukum adaik: pareso, mungkin, tanggo diamalkan oleh gerak anggota, yakni perbuatan anggota lahir, akhir kasudahan dasar adaik.

Ketahuilah dan pahamkanlah hai urang yang berakal, adopun jaso-jaso Niniak Datuak Katumangguangan dan Datuk Parpatih nan Sabatang di alam Minangkabau, di luhak nan tigo lareh nan duo, adolah dalam garih gadangnyo, limo parkaro:

1. Takluk kapado kabudian, umpamo bataranak, badusun, bakoto, banagari, bakampung bahalaman, barumah batanggo, bakapuak barangkiang, barumah gadang bagonjong, balambuang bapiriang, babalai bamusajik, balabuh batapian, baparik nan tarantang,babalai bapamedanan.

2. Takluk kapado ekonomi, janjang latih timbang sarugo, sawah ladang banda buatan, itiak, ayam, kambiang jo kudo, bantiang jo kabau bakambangan, padi masak jaguang maupeh, padi ladang batuai pulo.

\section{$/ 152 /$}

3. Takluk kapado adat istiadat, umpamonyo luhak dibari barajo, lareh dibarijunjuang. Nagari dibari bapang[h]ulu, kampuang dibarih batu, rumah dibari batungganai, suku dibari buah paruik, ketek dibari banamo, gadang dibari bagala, katigonyo balingkuang rundiang, gadangnyo balingkuang batu, lebanyo balingkuang tanah, sabanyo balingkuang aur, tagak indak tasundak, malingkuang indak tahampeh, adat diisi, limbago dituang, barih dipahek, takuak ditabang, bajanjang naiak, batanggo turun, baitu tagak tungkunyo.

4. Takluk kapado dasar hukum adaik, umpamonyo cupak nan duo, kato nan ampek, yaitu cupak usali dan cupak buatan, kato pusako, kato mufakat, kato dahulu batapi, kato kudian kato bajadi.

5. Takluk kapado undang-[undang] nan ampek pucuk, umpamonyo undang- undang nagari, undang urang dalam nagari, undang luhak, dan undangundangnan duo puluah. 


\section{Adaik Artinyo Nan Biaso Dipakai}

Adaik iyolah kebiasaan nan dipakai lagi nyato kabanarannyo, suatu ketetapan kenyataan nan dibarikan Tuhan kapado sakalian alam, alam mamakainyo. Itulah nan sabana adaik, undang papatahnyo /153/ nan indak lapuak dihujan, nan tidak lakang dipaneh, dibubuah indak layua, diasak indaknyo mati, itulah nan babuhua mati namonyo.

\section{Adaik itu Ampek Baginyo}

\section{Adaik Istiadat}

yaitu adaik nan dituntuik mamakainyo, dengan tuntutan nan wajib pado adaik kapado sagalo banso, suku di dalam lingkungnyo masing-masing, yakni adat nan diatur oleh niniak moyang sagalo banso dan suku-suku disaluruah alam,seperti adaik istiadaik alam Minangkabau, nan diatur oleh Niniak Datuak Katumangguangan dan Niniak Datuak Parpatiah Nan Sabatang. Saparti alamdibari barajo, lareh dibari bajunjuang, nagari dibari bapang[h]ulu, kampuangdibari batuah, rumah dibari batungganai, suku dibari babuah paruik, ketek dibari banamo, gadang dibari bagala.

Keteknyo balingkuang dindiang, gadangnyo balingkuang batu, lebanya balingkung tanah, basanyo balingkuang urek. Tagak indak tasundak, malenggang indak tatampeh. Adaik diisi limbago dituang, barih dipahek, takuak ditabang, bajanjang naik batanggo turun, baitu gatak tungkunyo. Undang-undang papatahnyo satapak tidaknyo naiak, satapak indaknyo turun, salangkah bapantang suruik, jikok dibubuah layur, diasak mati, karano indak satipak alam mamakainyo, hanyo basifat itulah adaik babuhul taguah salamonyo.

\section{Adaik Islamiah}

Artinyo adaik nan dituntuik mamakainyo, dengan /154/ tuntutan nan wajib pado sarak sagalo umat dan penganut agama islam dengan berpedoman kepada kitabbullah dan sunah Rasul Muhammad SAW, yakni quran dan hadis, ijmak dan kiyas yakni parundingan kesepakatan, adaik islamiah itu masuk kepada adaik nansabana adaik undang-undangnyo, tidak lapuk dihujan indak lakang dipaneh, dibubuah indaknyo layur, diasak indaknyo mati, khusus bagi orang baragama islam, tidak satipak alam mamakainyo, itulah adaik termasuk nan babuhul mati juo namonyo.

\section{Adaik Makdut}

Artinyo adaik dibiasokan dan diatur oleh urang-urang cadiak pandai, yakni urang tuo-tuo dan pang(h)ulu sarato urang-urang alim dan hakim-hakim dengan kerapatan nan disepakati, dengan kebulatan mufakat di tiap-tiap nagari di dalam alam Minangkabau. Bulek air jo pambuluh, bulek kato jo mufakaik, buleknyo sagiling, pipihnyo satapik, lah bulek mako diguluangkan, lah pipih mako dilayangkan. Undang-undangnyo lain lubuk lain ikannyo, lain padang lain bilalangnyo, lain nagari lain adatnyo, itulah adat nan babuhul arek namonyo. 


\section{Adaik Nan Taradaik}

Artinyo adaik nan biaso oleh urang banyak, nan tidak diatur oleh urang- urang ahli akal dan urang cadik pandai dengan kerapatan nan disapakati dengan kebulatan mufakat pado tiap-tiap nagari. Malahan adaik itu tiru maniru sajo,saparti adaik perhelatan, adaik pakaian, adaik permainan, dan adaik buni-bunian.

/155/ Undang-undang papatahnyo: elok samo dipakai, buruak samodibuang. Itulah adaik nan babuhul sentak namonyo.

Salain daripado itu ado pulo masuk adaik jahiliah. Disabuik adaik jahiliah artinyo kebiasaan urang jahil-jahil nan tidak memikirkan ujung akhir, lahir jo batin, buruk jo baik, rugi jo labo, malarat manfaat, seperti hiru biru,s-w-r-p sudi. Minum tuak, main judi, sabuang pupuah, barambuak jo dado, sahinggo sampai pulo tiru maniru. Tatapi adat jahiliah itu, tidak lagi dinamoi adat hanyo dinamoi sajo barhalo, karano sudah dibatakan dan dilarang oleh adat islamiah atau adat nansabana adat. Undang-undang papatahnyo, dihanyutkan ka air dareh dibanamkanka tanah lakang, tidak bulih dipakai lagi, itulah adat nan tidak.

/156/ Hukum Meisbatkan Sesuatu atau Menapikan Sesuatu

Adopun hukum itu tigo baginyo, partamo hukum pado adaik artinyo hukum nan biaso, kaduo hukum sarak, artinyo hukum agamo, katigo hukum aka nan bajelo.

1. Adopun hukum adaik itu ampek baginyo, partamo manggantungkan nan wujud kapado nan wujud, artinyo manggantungkan nan ado kapado nan ado, saparti ado kanyang karano ado makan pado adaik. Kaduo manggantungkan nan adam kapado nan adam, aratinyo manggantuangkan nan tiado kapado nan tiado, saparti tiado kanyang karano tidak makan pado adaik. Katigo manggantuangkan nan wujud kapado adam, aratinyo manggantungkan nan ado kapado nan tiado, saparti manggantungkan ado dingin karano tiado tutup. Kaampek, hukum manggantungkan nan adam kapado nan wujud, artinyo manggantuangkan nantiado kapado ado, saparti manggantungkan tiado dingin karano adonyo tutup.

2. Hukum sarak hukum agamo yaitu kaputusan, ketetapan dari kalam Allahta'ala nan bersangkut dengan perbuatan seseorang dengan qatib taklif dan qatlibwadak, dituntuik dengan tuntutan nan jazam dan ghairu jazam dan khayar, kalamAllah taala itu diturunkan Tuhan kapado Rasul-rasul dengan wahyu seperti nan /157/ tertulih di dalam Kitab Zabur kapado Dawud, Kitab Taurat kapado nabi Musa, Kitab Injil kapado Nabi Isa, dan kitab Alquran kapado nabi Muhammad SAW.

Pidato-pidato adat Minangkabau ini dipelajari dari Ayahanda:

Adjisman/Adjisam? Soetan Pamenan yang belajar sejak tahun 1934 s/d 1937dan pelajaran tambahan sesudah tahun-tahun tersebut dari guru-guru beliau:

1. Angku Labai g-l-s Sutan t-e-m-a-m-a-l dari Djaho Padang Panjang 
2. Angku Rabun dari Pitalah

3. Hadji Abdullah dari Sumpu

4. Nazarudin dari Koto nan IV Payokumbuah.

Oleh karena pelajaran pidato-pidato adat Minangkabau ini sudah mulai langka diperoleh, maka sangatlah terima kasih saya kepada ayah dan ibu St Pamenan yang telah bermurah hati meminjamkan buku Pidato Adat milik beliau yang sangat berharga untuk ditulis dan dipelajari. Ucapan terimakasih jua saya sampaikan atas keterangan-keterangan beliau tentang adat istiadat yang diberikantiap-tiap menjelang sholat zohor di Mesjid Pusat Pasar Medan.

A-k-i-n-y-a kita doakan kepada Allah subha nahu wa taala, semoga ayah dan ibu ST. Pamenan diberi usia yang panjang, hingga sisa usia tersebut dapat dimanfaatkan untuk mengabdi kepada Allah SWT. Semoga pula ilmu yang diberikan ini menjadi shadaqah Jariah dikemudian hari. Amin ya rabbal alamin

Medan, 1 Syawal 14011

Agustus $1981 \mathrm{M}$

Disetujui oleh

(Dt. St P-a-m-e-n A.G. Ismael Sutan Batuah) 